Z

1209

$\$ 664$

1962

ANTHRF 





\section{LIST OF PUBLICATIONS \\ OF THE}

\section{BUREAU OF AMERICAN ETHNOLOGY}

WITH INDEX TO AUTHORS AND TITLES

Revised to December 31, 1961

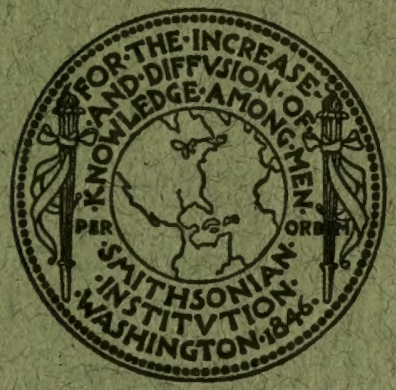




\section{SMITHSONIAN INSTITUTION LIBRARIES}

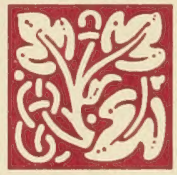

From the Library of

T. DALE STEWART 


\section{LIST OF PUBLICATIONS}

OF THE

\section{BUREAU OF AMERICAN ETHNOLOGY}

$z$

1209

S6l4

1962

WITH INDEX TO AUTHORS

ANTH, REF

\section{AND TITLES}

*

REVISED TO DECEMBER 31, 1961

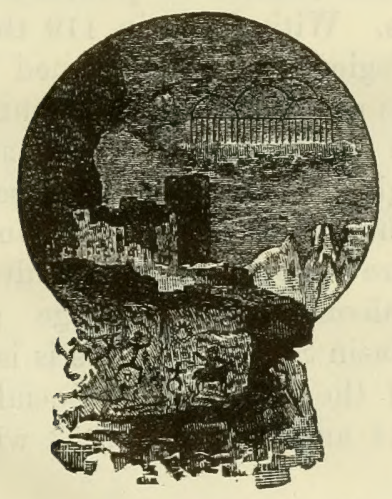

UNITED STATES

GOVERNMENT PRINTING OFFICE

WASHINGTON : 1962 


\section{$\mathrm{NO} \mathrm{T} \mathrm{E}$}

The publications of the Bureau of American Ethnology consist of Contributions to North American Ethnology, Annual Reports, Bulletins, Introductions, Miscellaneous Publications, and Publications of the Institute of Social Anthropology.

The series of Contributions, in quarto, was begun in 1877 by the Geographical and Geological Survey of the Rocky Mountain Region (J. W. Powell, director). Of the earlier numbers, printed under authority of special resolutions of Congress, volumes I, II (in two parts), and III had been completed when, in the year 1879, the Bureau of Ethnology was organized. In March 1881 the publication of volumes VI, VII, VIII, IX, and $\mathrm{X}$ was authorized, but the series was discontinued in 1895 , after volumes I to VII and IX had been completed. Volumes viII and $\mathrm{x}$ were never published.

The Annual Report series began with that for the year ended June 30,1880 . The Forty-eighth Report is an index to all the reports from the First to the Forty-eighth, and with its appearance the Annual Report series in royal octavo form terminated. Annual administrative reports of the Bureau are now issued as octavo pamphlets, and the ethnological papers that formerly accompanied the reports appear now in the Bulletin series.

The series of Bulletins was first authorized by Congress in 1886 . Today virtually all the researches published by the Bureau are included in this series. With Bulletin 119 the Bureau inaugurated a series of Anthropological Papers, designed as an outlet for brief articles. These papers are numbered consecutively, a Bulletin being devoted to them from time to time as they accumulate. A limited edition of Anthropological Papers is issued in separate form. Another series, River Basin Surveys Papers, was inaugurated with Bulletin 154. These papers are reports on the results of the Inter-Agency archeological and paleontological salvage program. A limited edition of the River Basin Surveys Papers is issued in separate form.

The publications of the Institute of Social Anthropology, 16 in number, began in 1944 and ended in 1953 with the termination of the Institute.

Besides the series mentioned, there have been issued small editions of 4 Introductions and of 14 Miscellaneous Publications.

Publications of the Bureau of American Ethnology are distributed free of charge, with the exception of the copies disposed of by the Superintendent of Documents. The quota allowed the Bureau is distributed mainly to libraries and other institutions of learning and to collaborators and others engaged in anthropological reasearch or in instruction. 


\section{CONTENTS}

PAGE

Annual Reports .

Bulletins............. 16

Publications of the Institute of Social Anthropology _.. _ _ .

Contributions to North American Ethnology _. .

Introductions . .

Miscellaneous Publications_.......... 48

Index to authors and titles... 



\title{
LIST OF PUBLICATIONS OF THE BUREAU OF AMERICAN ETHNOLOGY
}

\author{
ANNUAL REPORTS \\ (In royal octavo size)
}

First annual report of the Bureau of Ethnology to the Secretary of the Smithsonian Institution, 1879-80, by J. W. Powell, Director. $\mathrm{xxxv}+603$ pp., 346 figs. (incl. 54 pls.), map. 1881. Out of print.

Report of the Director. Pp. xI-xxxiII.

On the evolution of language, as exhibited in the specialization of the grammatic processes, the differentiation of the parts of speech, and the integration of the sentence; from a study of Indian languages, by J. W. Powell. Pp. 1-16.

Sketch of the mythology of the North American Indians, by J. W. Powell. Pp. 17-56.

Wyandot government: A short study of tribal society, by J. W. Powell. Pp. $57-69$.

On limitations to the use of some anthropologic data, by J. W. Powell. Pp. 71-86. Available in separate form.

A further contribution to the study of the mortuary customs of the North American Indians, by Dr. H. C. Yarrow, act. asst. surg., U.S. A[rmy]. Pp. 87-203, figs. 1-47.

Studies in Central American picture-writing, by Edward S. Holden, professor of mathematics, U.S. Naval Observatory. Pp. 205-245, figs. 48-60.

Cessions of land by Indian tribes to the United States: Illustrated by those in the State of Indiana, by C. C. Royce. Pp. 247-262, map.

Sign language among North American Indians compared with that among other peoples and deaf-mutes, by Garrick Mallery. Pp. 263-552, figs. 61-346.

Catalogue of linguistic manuscripts in the library of the Bureau of Ethnology, by James C. Pilling. Pp. 553-577.

Illustration of the method of recording Indian languages. From the manuscripts of Messrs. J. O. Dorsey, A. S. Gatschet, and S. R. Riggs. Pp. 579-589.

Index. Pp. 591-603.

Second annual report of the Bureau of Ethnology to the Secretary of the Smithsonian Institution, 1880-81, by J. W. Powell, Director. xxxviI +477 pp., 77 pls., figs. 1-35, 347-714 (382 of these forming 98 pls.), 2 maps. 1883 [1884]. Out of print.

Report of the Director. Pp. xv-xxxvir.

Zuñi fetiches, by Frank Hamilton Cushing. Pp. 3-45, pls. I-xI, figs. 1-3.

Myths of the Iroquois, by Erminnie A. Smith. Pp. 47-116, pls. xII-xv. 
Animal carvings from mounds of the Mississippi valley, by Henry W. Henshaw. Pp. 117-166, figs. 4-35.

Navajo silversmiths, by Dr. Washington Matthews, U.S. A[rmy]. Pp. 167178 , pls. $\mathrm{xvI}-\mathrm{xx}$.

Art in shell of the ancient Americans, by William II. Holmes. Pp. 179-305, pls. XXI-LXXvir.

Illustrated catalogue of the collections obtained from the Indians of New Mexico and Arizona in 1879, by James Stevenson. Pp. 307-422, figs. 347-697, map.

Illustrated catalogue of the collections obtained from the Indians of New Mexico in 1880, by James Stevenson. Pp. 423-465, figs. 698-714, map.

Index. Pp. 467-477.

Third annual report of the Bureau of Ethnology to the Secretary of the Smithsonian Institution, 1881-82, by J. W. Powell, Director. Lxxiv +606 pp., 44 pls., 200 ( +2 unnumbered) figs. 1884 [1885]. Out of print.

Report of the Director. Pp. XIII-LXxiv.

On activital similarities. Pp. Lxv-Lxxrv.

Notes on certain Maya and Mexican manuscripts, by Prof. Cyrus Thomas. Pp. 3-65, pls. I-Iv, figs. 1-10.

On masks, labrets, and certain aboriginal customs, with an inquiry into the bearing of their geographical distribution, by William Healey Dall, assistant, U.S. Coast Survey; honorary curator, U.S. National Museum. Pp. 67-202, pls. v-xxix. Available in separate form.

Omaha sociology, by Rev. J. Owen Dorsey. Pp. 205-370, pls. xxx-xxxıI, figs. 12-42.

Navajo weavers, by Dr. Washington Matthews, U.S. A[rmy]. Pp. 371-391, pls. xxxrv-xxxvirr, figs. 42-59.

Prehistoric textile fabrics of the United States, derived from impressions on pottery, by William H. Holmes. Pp. 393-425, pl. xxxıx, figs. 60-115.

Illustrated catalogue of a portion of the collections made by the Bureau of Ethnology during the field season of 1S81, by William H. Holmes. Pp. $427-510$, figs. $116-200$.

Illustrated catalogue of the collections obtained from the pueblos of Zuni, New Mexico, and Wolpi, Arizona, in 1881, by James Stevenson. Pp. 511594 , pls. xu-xulv. Available in separate form.

Index. Pp. 595-606.

Fourth annual report of the Bureau of Ethnology to the Secretary of the Smithsonian Institution, 1882-83, by J. W. Powell, Director. Lxirl +532 pp., 83 pls., 565 figs. 1886 [1887]. Out of print.

Report of the Director. Pp. xxvin-Lxirr.

Pictographs of the North American Indians. A preliminary paper, by Garrick Mallery. Pp. 3-256, pls. I-Lxxxır, figs. 1-111, 111a-209.

Pottery of the ancient Pueblos, by William II. Holmes. Pp. 257-360, figs. $210-360$.

Ancient pottery of the Mississippi Valley, by William H. IIolmes. Pp. 361436 , figs. $361-463$.

Origin and development of form and ornament in ceramic art, by William II. Holmes. Pp. 437-465, figs. 464-489. 
A study of Pueblo pottery as illustrative of Zuni culture-growth, by Frank Hamilton Cushing. Pp. 467-521, figs. 490-564.

Index. Pp. 523A-532.

Fifth annual report of the Bureau of Ethnology to the Secretary of the Smithsonian Institution, 1883-84, by J. W. Powell, Director. LIII +564 pp., 23 pls. (incl. 2 maps), 77 figs. 1887 [1888]. Out of print.

Report of the Director. Pp. xviI-LIII.

Burial mounds of the northern sections of the United States, by Prof. Cyrus Thomas. Pp. 3-119, pls. I-vi, figs. 1-49.

The Cherokee Nation of Indians: A narrative of their official relations with the Colonial and Federal governments, by Charles C. Royce. Pp. 121378, pls. VII-IX (maps).

The mountain chant: A Navajo ceremony, by Dr. Washington Matthews, U.S. A[rmy]. Pp. 379-467, pls. X-xviII, figs. 50-59.

The Seminole Indians of Florida, by Clay MacCauley. Pp. 469-531, pl. XIX, figs. 60-77.

The religious life of the Zuni child, by Mrs. Tilly E. Stevenson. Pp. 533555 , pls. $\mathrm{xx}-\mathrm{xx}$ IIr.

Index. Pp. 557-564.

Sixth annual report of the Bureau of Ethnology to the Secretary of the Smithsonian Institution, 1884-85, by J. W. Powell, Director. Lviri +675 pp. (incl. 6 pp. of music), 10 pls. (incl. 3 maps), 546 figs., 44 small unnumbered cuts. 1888 [1889]. Out of print.

Report of the Director. Pp. xxIII-LviIr.

Ancient art of the province of Chiriqui, Colombia, by William H. Holmes. Pp. 3-187, pl. I (map), figs. 1-285.

A study of the textile art in its relation to the development of form and ornament, by William H. Holmes. Pp. 189-252, figs. 286-358.

Aids to the study of the Maya codices, by Prof. Cyrus Thomas. Pp. 253371, figs. $359-388$.

Osage traditions, by Rev. J. Owen Dorsey. Pp. 373-397, fig. 389.

The Central Eskimo, by Dr. Franz Boas. Pp. 399-669, pls. II-X (incl. 2 maps), figs. 390-546.

Index. Pp. 671-675.

Seventh annual report of the Bureau of Ethnology to the Secretary of the Smithsonian Institution, 1885-86, by J. W. Powell, Director. XLIII +409 pp., 27 pls. (incl. map), 39 figs. 1891 [1892]. Out of print.

Report of the Director. Pp. $\mathbf{x v}$-xuI.

Indian linguistic families of America north of Mexico, by J. W. Powell. Pp. 1-142, pl. I (map).

The Midé'wiwin or "Grand Medicine Society" of the Ojibwa, by IV. J. Hoffman. Pp. 143-300, pls. II-Xxirr, figs. 1-39.

The sacred formulas of the Cherokees, by James Mooney. Pp. 301-397, pls. XxIV-XXvir.

Index. Pp. 399-409. 
Eighth annual report of the Bureau of Ethnology to the Secretary of the Smithsonian Institution, 1886-87, by J. W. Powell, Director. xxxvi +298 pp., 123 pls., 118 figs. 1891 [1893]. Out of print.

Report of the Director. Pp. xir-xxxvi.

$\Lambda$ study of Pueblo architecture: Tusayan and Cibola, by Victor Mindeleff. Pp. 3-228, pls. I-cXI, figs. 1-114.

Ceremonial of Hasjelti Dailjis and mythical sand painting of the Navajo Indians, by James Stevenson. Pp. 229-285, pls. cxiI-cxxıI, figs. 115-118. Index. Pp. 287-298.

Ninth annual report of the Bureau of Ethnology to the Secretary of the Smithsonian Institution, 1887-88, by J. W. Powell, Director. XLVI+617 pp., 8 pls., 448 figs. 1892 [1893]. Out of print.

Report of the Director. Pp. Xix-XLvi.

Ethnological results of the Point Barrow Expedition, by John Murdoch, naturalist and observer, International Polar Expedition to Point Barrow, Alaska, 1881-1883. Pp. 3-441, pls. I-II (maps), figs. 1-428.

The medicine-men of the Apache, by John G. Bourke, Captain, Third Cavalry, U.S. Army. Pp. 443-603, pls. III-viII, figs. 429-448.

Index. Pp. 605-617.

Tenth annual report of the Bureau of Ethnology to the Secretary of the Smithsonian Institution, 1888-89, by J. W. Powell, Director. $\mathrm{xxx}+822 \mathrm{pp} ., 54$ pls., 1291 figs., 116 small unnumbered cuts. 1893 [1894]. Out of print.

Report of the Director. Pp. III-XXX.

Picture-writing of the American Indians, by Garrick Mallery. Pp. 3-807, pls. I-LIV, figs. $1-145,145 a-1290$.

Index. Pp. 809-822.

Eleventh annual report of the Bureau of Ethnology to the Secretary of the Smithsonian Institution, 1889-90, by J. W. Powell, Director. xLVII +553 pp., 50 pls., 200 figs. 1894. Out of print.

Report of the Director. Pp. xxI-Xuvir.

The Sia, by Matilda Coxe Stevenson. Pp. 3-157, pls. I-xxxv, figs. 1-20.

Ethnology of the Ungava District, Hudson Bay Territory, by Lucien M. Turner. [Edited by John Murdoch.] Pp. 159-350, pls. xxxvi-XLIII, figs. $21-155$.

A study of Siouan cults, by James Owen Dorsey. Pp. 351-544, pls. Xurv-L, figs. 156-200.

Index. Pp. 545-553.

Twelfth annual report of the Bureau of Ethnology to the Secretary of the Smithsonian Institution, 1890-91, by J. W. Powell, Director. XLVIII +742 pp., 42 pls., 344 figs. 1894. Out of print.

Report of the Director. Pp. xIX-Xuvirr.

Report on the mound explorations of the Bureau of Ethnology, by Cyrus Thomas. Pp. 3-730.

Index. Pp. 731-742. Out of print. 
Thirteenth annual report of the Bureau of Ethnology to the Secretary of the Smithsonian Institution, 1891-92, by J. W. Powell, Director. LIX +462 pp., 60 pls., 330 figs. 1896. Out of print.

Report of the Director. Pp. xIx-LIX.

Prehistoric textile art of Eastern United States, by William Henry Holmes. Pp. 3-46, pls. I-IX, figs. 1-28.

Stone art, by Gerard Fowke. Pp. 47-178, figs. 29-278.

Aboriginal remains in Verde Valley, Arizona, by Cosmos Mindeleff. Pp. 179-261, pls. X-L, figs. 279-305.

Omaha dwellings, furniture, and implements, by James Owen Dorsey. Pp. 263-288, figs. 306-327.

Casa Grande ruin, by Cosmos Mindeleff. Pp. 289-319, pls. LI-Lx, figs. 328-330.

Outlines of Zuñi creation myths, by Frank Hamilton Cushing. Pp. 321-447 Index. Pp. 449-462.

Fourteenth annual report of the Bureau of Ethnology to the Secretary of the Smithsonian Institution, 1892-93, by J. W. Powell, Director. Two parts. LXI+1136 pp., 122 pls., 104 figs. 1896 [1897]. Out of print.

Part 1:

Report of the Director. Pp. Xxv-LXI.

The Menomini Indians, by Walter James Hoffman, M. D. Pp. 3-328, pls. I-XXXvir, figs. 1-55.

The Coronado Expedition, 1540-1542, by George Parker Winship. Pp. 329-613, pls. xxxviII-LXxxIv.

Index. Pp. 615-637.

Part 2:

The Ghost-dance religion and the Sioux outbreak of 1890, by James Mooney. Pp. 641-1110, pls. LXxxv-CxxII, figs. 56-104.

Index. Pp. 1111-1136.

Fifteenth annual report of the Bureau of Ethnology to the Secretary of the Smithsonian Institution, 1893-94, by J. W. Powell, Director. cxxi +366 pp., frontispiece, 125 pls., 49 figs. 1897. Out of print.

Report of the Director. Pp. $\mathrm{xv}-\mathrm{CxxI}$.

On regimentation. Pp. civ-cxxI.

Stone implements of the Potomac-Chesakeape tidewater province, by William

Henry Holmes. Pp. 3-152, pls. I-CII and frontispiece, figs. 1-29a.

The Siouan Indians: A preliminary sketch, by W J McGee. Pp. 153-204.

Siouan sociology: A posthumous paper, by James Owen Dorsey. Pp. 205-244, figs. 30-38.

Tusayan katcinas, by Jesse Walter Fewkes. Pp. 245-313, pls. cIV-cxI, figs. 39-48.

The repair of Casa Grande ruin, Arizona, in 1891, by Cosmos Mindeleff. Pp. 315-349, pls. cXII-cXXv.

Index. Pp. 351-366. 
Sixteenth annual report of the Bureau of American Ethnology to the Secretary of the Smithsonian Institution, 1894-95, by J. W. Powell, Director. cxix +326 pp., 81 pls., 83 figs. 1897. Out of print.

Report of the Director. Pp. xili-cxix.

List of publications of the Bureau of American Ethnology. Pp. cI-cxix. Primitive trephining in Peru, by Manuel Antonio Muñiz, M. D., and W $J$ McGee. Pp. 3-72, pls. I-XL.

The cliff ruins of Canyon de Chelly, Arizona, by Cosmos Mindeleff. Pp. 73-198, pls. XLI-LXIIr, figs. 1-83.

Day symbols of the Maya year, by Cyrus Thomas. Pp. 199-265, pls. LXIV-LXIX.

'Tusayan snake ceremonies, by Jesse Walter Fewkes. Pp. 267-312, pls. LXX-LXXXI.

Index. Pp. 313-326.

Seventeenth annual report of the Bureau of American Ethnology to the Secretary of the Smithsonian Institution, 1895-96, by J. W. Powell, Director. Two parts, xcIII+1-128, $129^{*}-344^{*}, 129-468 ; 469-752$ pp., 182 pls., 357 figs. 1898 [part 1, 1900; part 2, 1901]. Out of print.

Part 1:

Report of the Director. Pp. xxv-xcin.

List of publications of the Bureau of American Ethnology. Pp. LXxv-Xcir.

The Seri Indians, by W J McGee. Pp. 1-128, 129*-344*, pls. I-LVI, figs. $1-42$.

Comparative lexicology, by J. N. B. Hewitt. Pp. $299 *-344 *$.

Calendar history of the Kiowa Indians, by James Mooney. Pp. 129-445, pls. LVII-LXXXI, figs. 43-229.

Index. Pp. 447-468.

Part 2:

Navaho houses, by Cosmos Mindeleff. Pp. 469-517, pls. LxxxiI-xc, figs. 230-244.

Archeological expedition to Arizona in 1895, by Jesse Walter Fewkes. Pp. 519-744, pls. хcı $a$, хcı $b-c l x x v$, figs. 245-357.

Index. Pp. 745-752.

Eighteenth annual report of the Bureau of American Ethnology to the Secretary of the Smithsonian Institution, 1896-97, by J. W. Powell, Director. Two parts, LvIr $+1-518$; 519-997 pp., 174 pls., 165 figs. 1899 [part 1, 1901, part 2, 1902]. Out of print.

Part 1:

Report of the Director. Pp. xxıI-LviI.

The Eskimo about Bering Strait, by Edward William Nelson. Pp. 3-518, pls. I-Cvir, figs. 1-165.

Part 2:

Indian land cessions in the United States, compiled by Charles C. Royce, with an introduction by Cyrus Thomas. Pp. 521-964, pls. Cvin-cLxxıv.

Index to parts 1 and 2. Pp. 965-997. 
Nineteenth annual report of the Bureau of American Ethnology to the Secretary of the Smithsonian Institution, 1897-98, by J. W. Powell, Director. Two parts, xcII+1-568, 569*-576*; 569-1160 pp., frontispiece, 79 pls., 49 figs. 1900 [1902]. Out of print.

Part 1:

Report of the Director. Pp. IX-xcrr, frontispiece.

Esthetology, or the science of activities designed to give pleasure. Pp. LV-Xcir.

Myths of the Cherokee, by James Mooney. Pp. 3-548, pls. I-xx, figs. 1-2.

Index. Pp. 549-568, 549*-576*.

Part 2:

Tusayan migration traditions, by Jesse Walter Fewkes. Pp. 573-633.

Localization of Tusayan clans, by Cosmos Mindeleff. Pp. 635-653, pls. XXI-XxVIII, fig. 3. (Available in separate form.)

Mounds in northern Ifonduras, by Thomas Gann. Pp. 655-692, pls. xxrxxxxıx, figs. 4-7.

Mayan calendar systems, by Cyrus Thornas. Pp. 693-819, pls. Xu-XLma, XLIIIb, XLIV, figs. 8-17a, 17b-22.

Primitive numbers, by W J McGee. Pp. 821-851. Available in separate form.

Numeral systems of Mexico and Central America, by Cyrus Thomas. Pp. 853-955, figs. 23-41. Available in separate form.

Tusayan Flute and Snake ceremonies, by Jesse Walter Fewkes. Pp. 9571011, pls. XLv-LXV, figs. 42-46.

The wild-rice gatherers of the upper lakes: A study in American primitive economics, by Albert Ernest Jenks. Pp. 1013-1137, pls. Lxvi-LXxix, figs. $47-48$.

Index. Pp. 1139-1160.

Twentieth annual report of the Bureau of American Ethnology to the Secretary of the Smithsonian Institution, 1898-99, by J. W. Powell, Director. CCxxiv +237 pp., 180 pls., 79 figs. 1903. Out of print.

Report of the Director. Pp. vir-ccxxiv.

Technology, or the science of industries. Pp. xxix-Lvir. Available in separate form.

Sociology, or the science of institutions. Pp. Lrx-cxxxvil. Available in separate form.

Philology, or the science of activities designed for expression. Pp. cxxxixcxLx. Available in separate form.

Sophiology, or the science of activities designed to give instruction. Pp. CLXXI-CXCVIr. Available in separate form.

List of publications of the Bureau of American Ethnology. Pp. cxcrxccxxiv.

Aboriginal pottery of the eastern United States, by IV. II. Holmes. Pp

1-201, pls. I-CLXXvir, figs. 1-79.

Index. Pp. 203-237. 
Twenty-first annual report of the Bureau of American Ethnology to the

Secretary of the Smithsonian Institution, 1899-1900, by J. W. Powell, Director. $\mathrm{xL}+360$ pp., 69 pls. 1903 . Out of print.

Report of the Director. Pp. VII-XI, pl. I (map).

Hopi katcinas, drawn by native artists, by Jesse Walter Fewkes. Pp. 3-126, pls. II-LXIII.

Iroquoian cosmology, by J. N. B. Hewitt. First part. Pp. 127-339, pls. LXIV-LXIX.

Index. Pp. 341-360.

Twenty-second annual report of the Bureau of American Ethnology to the Secretary of the Smithsonian Institution, 1900-1901, J. W. Powell, Director. Two parts, xuIv+1-320; 1-372 pp., 91 pls., 181 figs. 1904. Out of print.

\section{Part 1:}

Report of the Director. Pp. vir-XLIv.

Two summers' work in pueblo ruins, by Jesse Walter Fewkes. Pp. 3-195, pls. I-LXX, figs. 1-122.

Mayan calendar systems--II, by Cyrus Thomas. Pp. 197-305, pls. LxxiLxxxır, figs. 123-170. Available in separate form.

Index. Pp. 307-320.

Part 2:

The Hako: A Pawnee ceremony, by Alice C. Fletcher (assisted by James R. Murie; music transcribed by Edwin S. Tracy). Pp. 5-368, pls. Lxxxin$\mathrm{xcr}$, figs. 171-181.

Index. Pp. 369-372.

Twenty-third annual report of the Bureau of American Ethnology to the Secretary of the Smithsonian Institution, 1901-2, J. W. Powell, Director. XLV +634 pp., 139 pls., 34 figs. 1904 [1905]. Out of print.

Report of the Director. Pp. viI-XLV.

The Zuni Indians: Their mythology, esoteric fraternities, and ceremonies, by Matilda Coxe Stevenson. Pp. 3-608.

Index. Pp. 609-634.

Twenty-fourth annual report of the Bureau of American Ethnology to the Secretary of the Smithsonian Institution, 1902-3, H. W. Holmes, Chief. xu+846 pp., 21 pls., 1112 figs. 1907. Out of print.

Report of the Chief. Pp. viI-xL.

Games of the North American Indians, by Stewart Culin. Pp. 3-809.

Index. Pp. 811-846.

\section{Twenty-fifth annual report of the Bureau of American Ethnology to} the Secretary of the Smithsonian Institution, 1903-4. xxIx +296 pp., 129 pls., 70 figs. 1907. Out of print.

Report of the Chief [W. H. Holmes]. Pp. IV-xxIx.

The aborigines of Porto Rico and neighboring islands, by Jesse Walter Fewkes. Pp. 3-220, pls. I-cxni, figs. 1-43. 
Certain antiquities of eastern Mexico, by Jesse Walter Fewkes. Pp. 221-284, pls. xcrv-cxxrx, figs. 44-70.

Index. Pp. 285-296.

Twenty-sixth annual report of the Bureau of American Ethnology to the Secretary of the Smithsonian Institution, 1904-5. xxxi +512 pp., 58 pls., 117 figs. 1908. Out of print.

Report of the Chief [W. H. Holmes]. Pp. vII-XXxI.

The Pima Indians, by Frank Russell. Pp. 3-389, pls. I-Xuvir, figs. 1-102. Social condition, beliefs, and linguistic relationship of the Tlingit Indians, by John R. Swanton. Pp. 391-485, pls. xLVIrI-LVIII, figs. 103-117.

Index. Pp. 487-512.

\section{Twenty-seventh annual report of the Bureau of American Ethnology}

to the Secretary of the Smithsonian Institution, 1905-6. $672 \mathrm{pp}$., 65 pls., 132 figs. 1911. Out of print.

Report of the Chief [W. H. Holmes]. Pp. 5-14.

The Omaha tribe, by Alice C. Fletcher and Francis La Flesche. Pp. 17-654. Index. Pp. 655-672.

Twenty-eighth annual report of the Bureau of American Ethnology to the Secretary of the Smithsonian Institution, 1906-7. 308+xxxv pp., 103 pls., 68 figs. 1912.

Report of the Chief [W. H. Holmes]. Pp. 7-22.

Casa Grande, Arizona, by Jesse Walter Fewkes. Pp. 25-179, pls. 1-78, figs. 1-54.

Antiquities of the upper Verde River and Walnut Creek valleys, Arizona, by Jesse Walter Fewkes. Pp. 181-220, pls. 79-102, figs. 55-68.

Preliminary report on the linguistic classification of Algonquian tribes, by Truman Michelson. Pp. 221-290b, pl. 103 (map). (Available in separate form.)

Index. Pp. 291-308.

List of publications of the Bureau of American Ethnology. Pp. I-xxxv.

Twenty-ninth annual report of the Bureau of American Ethnology to the Secretary of the Smithsonian Institution, 1907-8. 636 pp., 21 pls., 31 maps, 1 diagram. 1916. Out of print.

Report of the Chief [W. H. Holmes]. Pp. 7-25.

The ethnogeography of the Tewa Indians, by John Peabody Harrington. Pp. 29-618. pls. 1-21, maps 1-29A-30, diagram 1.

Index. Pp. 619-636.

Thirtieth annual report of the Bureau of American Ethnology to the Secretary of the Smithsonian Institution, 1908-9. 453 pp., 7 pls., 6 figs. 1915. Out of print.

Report of the Chief [W. H. Holmes]. Pp. 7-28.

Ethnobotany of the Zuñi Indians, by Matilda Coxe Stevenson. Pp. 31-102, pls. 1-3.

An inquiry into the animism, and folk-lore of the Guiana Indians, by Walter E. Roth. Pp. 103-386, pls. 4-7, figs. 1-6.

List of publications of the Bureau of American Ethnology. Pp. 387-425.

Index. Pp. 427-453. 
Thirty-first annual report of the Bureau of American Ethnology to the Secretary of the Smithsonian Institution, 1909-10. 1037 pp., 3 pls., 24 figs. 1916. Out of print.

Report of the Ethnologist-in-charge [F. W. Hodge]. Pp. 5-26.

Tsimshian mythology, by Franz Boas. Pp. 29-1037.

Thirty-second annual report of the Bureau of American Ethnology to the Secretary of the Smithsonian Institution, 1910-11. $819 \mathrm{pp}$. 1918. Out of print.

Report of the Ethnologist-in-charge [F. W. Hodge]. Pp. 7-34.

Seneca fiction, legends, and myths. Collected by Jeremiah Curtin and J. N. B. Hewitt; edited by J. N. B. Hewitt. Pp. 37-813.

Index. Pp. 815-819.

Thirty-third annual report of the Bureau of American Ethnology to the Secretary of the Smithsonian Institution, 1911-12. 677 pp., 95 pls., 112 figs. 1919. Out of print.

Report of the Ethnologist-in-charge [F. W. Hodge]. Pp. 7-38.

Note on the accompanying papers. Pp. 39-40.

Uses of plants by the Indians of the Missouri River region, by Melvin Randolph Gilmore. Pp. 43-154, pls. 1-30a. Available in separate form.

Preliminary account of the antiquities of the region between the Mancos and La Plata Rivers in southwestern Colorado, by Earl H. Morris. Pp. 155206, pls. 31-75, figs. 1-11. Available in separate form.

Designs on prehistoric Hopi pottery, by Jesse Walter Fewkes. Pp. 207-284, pls. 76-90, figs. 12-112.

The Hawaiian romance of Laieikawai, by Martha Warren Beckwith. Pp. 285-666, pls. 91-95.

Index. Pp. 667-677.

Thirty-fourth annual report of the Bureau of American Ethnology to the Secretary of the Smithsonian Institution, 1912-13. 281 pp., 120 pls., 69 figs. 1922. Out of print.

Report of the Ethnologist-ln-charge [F. W. Hodge]. Pp. 5-32.

A prehistoric island culture area of America, by J. Walter Fewkes. Pp. 35271, pls. 1-120, figs. 1-69.

Index. Pp. 273-281.

Thirty-fifth annual report of the Bureau of American Ethnology to the Secretary of the Smithsonian Institution, 1913-14. Two parts, $\mathrm{XI}+794$; viII + 795-1481 pp. 1921.

Part 1:

Report of the Ethnologist-in-charge [F. W. Hodge]. Pp. 7-37.

Note on the accompanying paper. Pp. 39-40.

Ethnology of the Kwakiutl, by Franz Boas (based on data collected by George Hunt). Pp. 43-794.

Index. Pp. I-XI. 
Part 2:

Ethnology of the Kiwakiutl [continued], by Franz Boas (based on data collected by George Hunt). Pp. vir + 795-1473.

Index. Pp. 1475-1481.

Thirty-sixth annual report of the Bureau of American Ethnology to the Secretary of the Smithsonian Institution, 1914-15. 604 pp., 23 pls., 15 figs. 1921. Out of print.

Report of the Ethnologist-in-charge [F. W. Hodge]. Pp. 7-34.

The Osage tribe: Rite of the chiefs; sayings of the ancient men, by Francis La

Flesche. Pp. 37-597, pls. 1-23, figs. 1-15.

Index. Pp. 599-604.

Thirty-seventh annual report of the Bureau of American Ethnology to the Secretary of the Smithsonian Institution, 1915-16. viI +560 pp., 58 pls., 38 figs. 1923. Out of print.

Report of the Ethnologist-in-charge [F. W. Hodge]. Pp. 1-31.

The Vinnebago tribe, by Paul Radin. Pp. 35-550, pls. 1-58, figs. 1-38.

Index. Pp. 551-560.

Thirty-eighth annual report of the Bureau of American Ethnology to the Secretary of the Smithsonian Institution, 1916-17. vrI +745 pp., 183 pls., 341 figs. 1924. Out of print.

Report of the Ethnologist-in-charge [F. W. Hodge]. Pp. 1-21.

An introductory study of the arts, crafts, and customs of the Guiana Indians, by Walter Edmund Roth. Pp. 25-720, pls. 1-183, figs. 1-341.

Index and glossary. Pp. 721-745.

Thirty-ninth annual report of the Bureau of American Ethnology to the Secretary of the Smithsonian Institution, 1917-18. 636 pp., 17 pls., 4 figs. 1925. Out of print.

Report of the Chief [J. W. Fewkes]. Pp. 7-28.

The Osage tribe: The rite of vigil, by Francis La Flesche. Pp. 31-630, pls. 1-17, figs. 1-4.

Index. Pp. 631-636.

Fortieth annual report of the Bureau of American Ethnology to the Secretary of the Smithsonian Institution, 1918-19. viI +664 pp., 2 pls., 2 figs. 1925. Out of print.

Report of the Chief [J. W. Fewkes]. Pp. 1-20.

The mythical origin of the White Buffalo Dance of the Fox Indians, by Truman Michelson. Pp. 23-289, pl. 1, fig. 1.

The autobiography of a Fox Indian woman, by Truman Michelson. Pp. 291-349.

Notes on Fox mortuary customs and beliefs, by Truman Michelson. Pp. 351-496.

Notes on the Fox society known as "Those who worship the Little Spotted Buffalo," by Truman Michelson. Pp. 497-539, pl. 2, fig. 2.

The traditional origin of the Fox society known as "The singing around rite," by Truman Michelson. Pp. 541-658.

Index. Pp. 659-664. 
Forty-first annual report of the Bureau of American Ethnology to the Secretary of the Smithsonian Institution, 1919-24. Ix+626 pp., 137 pls., 201 figs., frontispiece, map in pocket. 1928. Out of print.

Reports of the Chief [J. W. Fewkes] for 1919-20, 1920-21, 1921-22, 1922-23, 1923-24. Pp. 1-116.

Coiled basketry in British Columbia and surrounding region, by H. K. Haeberlin, James A. Teit, and Helen H. Roberts, under the direction of Franz Boas. Pp. 119-484, frontispiece, map, pls. 1-94, figs. 1-122a.

Two prehistoric villages in Middle Tennessee,by William Edward Myer. Pp. 485-614, pls. 95-137, figs. 123-200.

Index. Pp. 615-626.

Forty-second annual report of the Bureau of American Ethnology to the Secretary of the Smithsonian Institution, 1924-25. vII +900 pp., 17 pls., 108 figs. 1928. Out of print.

Report of the Chief [J. W. Fewkes]. Pp. 1-19.

Social organization and social usages of the Indians of the Creek Confederacy, by John R. Swanton. Pp. 23-472, pls. 1-7, figs. 1-107.

Religious beliefs and medical practices of the Creek Indians, by John R. Swanton. Pp. 473-672, pls. 8-13, fig. 108.

Aboriginal culture of the Southeast, by John R. Swanton. Pp. 673-726.

Indian trails of the Southeast, by William E. Myer. Pp. 727-857, pls. 14-17. Index. Pp. 859-900.

Forty-third annual report of the Bureau of American Ethnology to the Secretary of the Smithsonian Institution, 1925-26. viI +828 pp., 44 pls., 9 figs. 1928. Out of print.

Report of the Chief [J. W. Fewkes]. Pp. 1-19.

The Osage tribe: Two versions of the child-naming rite, by Francis La Flesche. Pp. 23-164, pls. 1-12, figs. 1-8. Available in separate form.

Wawenock myth tests from Maine, by Frank G. Speck. Pp. 165-197, pl. 13. Available in separate form.

Native tribes and dialects of Connecticut: A Mohegan-Pequot diary, by Frank G. Speck. Pp. 199-287, pls. 14-42. Available in separate form.

Picuris children's stories, with texts and songs, by J. P. Harrington and Helen H. Roberts. Pp. 289-447, pls. 43-44, fig. 9.

Iroquoian cosmology. Second part, with introduction and notes, by J. N. B. Hewitt. Pp. 449-819. Available in separate form.

Index. Pp. 821-828.

Forty-fourth annual report of the Bureau of American Ethnology to the Secretary of the Smithsonian Institution, 1926-27. viI +555 pp., 98 pls., 16 figs. 1928. Out of print.

Report of the Chief [J. W. Fewkes]. Pp. 1-19.

Exploration of the Burton Mound at Santa Barbara, California, by John P. Harrington. Pp. 23-168, pls. 1-27, figs. 1-2. Available in separate form. Social and religious beliefs and usages of the Chickasaw Indians, by John R.

Swanton. Pp. 169-273, fig. 3. Available in separate form. 
Uses of plants by the Chippewa Indians, by Frances Densmore. Pp. 275-397, pls. 28-63.

Archeological investigations-II, by Gerard Fowke. Pp. 399-540, pls. 64-98, figs. 4-16. Available in separate form.

Index. Pp. 541-555.

Forty-fifth annual report of the Bureau of American Ethnology to the Secretary of the Smithsonian Institution, 1927-28. viI +857 pp., 29 pls., 49 figs. 1930. Out of print.

Report of the Chief Clerk [H. W. Dorsey]. Pp. 1-19.

The Salishan tribes of the western plateaus, by James A. Teit, edited by Franz Boas. Pp. 23-396, pls. 1-4, figs. 1-39. Available in separate form.

Tattooing and face and body painting of the Thompson Indians, British Columbia, by James A. Teit, edited by Franz Boas. Pp. 397-439, pls. 5-13, figs. 40-47. Available in separate form.

Ethnobotany of the Thompson Indians of British Columbia, based on field notes by James A. Teit, edited by Elsie Viault Steedman. Pp. 441-522. Available in separate form.

The Osage tribe: Rite of the Wa-xo'-be, by Francis La Flesche. Pp. 523-833, pls. 14-29, figs. 46-47 [figure numbers duplicated]. Available in separate form.

Index. Pp. 835-857.

Forty-sixth annual report of the Bureau of American Ethnology to the Secretary of the Smithsonian Institution, 1928-29. viI +654 pp., 80 pls., 35 figs. 1930. Out of print.

Report of the Chief [M. W. Stirling]. Pp. 1-16.

Anthropological survey in Alaska, by Aleš Hrdlička. Pp. 19-374, pls. 1-61, figs. 1-29.

Indian tribes of the Upper Missouri, by Edwin Thompson Denig, edited with notes and biographical sketch by J. N. B. Hewitt. Pp. 375-628, pls. 62-80, figs. 30-35. Available in separate form.

Index. Pp. 629-654.

\section{Forty-seventh annual report of the Bureau of American Ethnology to}

the Secretary of the Smithsonian Institution, 1929-30, vII+1108 pp., 61 pls., 32 figs., 1 map. 1932. Out of print.

Report of the Chief [M. W. Stirling]. Pp. 1-14.

The Acoma Indians, by Leslie A. White. Pp. 17-192, pls. 1-16, figs. 1-6.

Isleta, New Mexico, by Elsie Clews Parsons. Pp. 193-466, pls. 17-20, figs. 1-26, map.

Introduction to Zuñi ceremonialism, by Ruth L. Bunzel. Pp. 467-544.

Zuñi origin myths, by Ruth L. Bunzel. Pp. 545-609.

Zuñi ritual poetry, by Ruth L. Bunzel. Pp. 611-835.

Zuñi katcinas: An analytical study, by Ruth L. Bunzel. Pp. 837-1086, pls. 21-61.

Index. Pp. 1087-1108.

(All papers available in separate form.) 
Forty-eighth annual report of the Bureau of American Ethnology to the Secretary of the Smithsonian Institution, 1930-31. $v+1221$ pp. 1933.

Report of the Chief [M. W. Stirling]. Pp. 1-21.

General Index, Annual Reports of the Bureau of American Ethnology, Vols. 1 to 48 (1879-1931) [Washington, D.C., 1881-1933], compiled by Biren Bonnerjea. Pp. 25-1221.

Note.-The Forty-eighth Annual Report of the Bureau is the last of this series published in royal octavo size with accompanying scientific papers. Subsequent annual reports of the Bureau will consist only of the administrative report, which will be issued in octavo form.

Forty-ninth annual report of the Bureau of American Ethnology [M. W. Stirling, Chief] to the Secretary of the Smithsonian Institution, 1931-32. vi+8 pp. 1933. Out of print.

Fiftieth annual report of the Bureau of American Ethnology [M. W. Stirling, Chief] to the Secretary of the Smithsonian Institution, 1932-33. 7 pp. 1933. Out of print.

Fifty-first annual report of the Bureau of American Ethnology [M. W. Stirling, Chief] to the Secretary of the Smithsonian Institution, 1933-34. 8 pp. 1935. Out of print.

Fifty-second annual report of the Bureau of American Ethnology [M. W. Stirling, Chief] to the Secretary of the Smithsonian Institution, 1934-35. 8 pp. 1935. Out of print.

Fifty-third annual report of the Bureau of American Ethnology [M. IV. Stirling, Chief] to the Secretary of the Smithsonian Institution, 1935-36. 8 pp. 1937. Out of print.

Fifty-fourth annual report of the Bureau of American Ethnology [M. W. Stirling, Chief] to the Secretary of the Smithsonian Institution, 1936-37. 9 pp. 1938. Out of print.

Fifth-fifth annual report of the Bureau of American Ethnology [M. W. Stirling, Chief] to the Sccretary of the Smithsonian Institution, 1937-38. 8 pp. 1939.

Fifty-sixth annual report of the Bureau of American Ethnology [M. W. Stirling, Chief] to the Secretary of the Smithsonian Institution, 1938-39. 9 pp. 1940. Out of print.

Fifty-seventh annual report of the Bureau of American Ethnology [M. W. Stirling, Chief] to the Secretary of the Smithsonian Institution, 1939-40. $10 \mathrm{pp}$. 1941. Out of print. 
Fifty-eighth annual report of the Bureau of American Ethnology [M. W. Stirling, Chief] to the Secretary of the Smithsonian Institution, 1940-41. 13 pp. 1942. Out of print.

Fifty-ninth annual report of the Bureau of American Ethnology [M. W. Stirling, Chief] to the Secretary of the Smithsonian Institution, 1941-42. $12 \mathrm{pp}$. 1943. Out of print.

Sixtieth annual report of the Bureau of American Ethnology [M. W. Stirling, Chief] to the Secretary of the Smithsonian Institution, 1942-43. 9 pp. 1944. Out of print.

Sixty-first annual report of the Bureau of American Ethnology [M. W. Stirling, Chief] to the Secretary of the Smithsonian Institution, 1943-44. $8 \mathrm{pp}$. 1946. Out of print.

Sixty-second annual report of the Bureau of American Ethnology [M. W. Stirling, Chief] to the Secretary of the Smithsonian Institution, 1944-45. 9 pp. 1946. Out of print.

Sixty-third annual report of the Bureau of American Ethnology [M. IV. Stirling, Chief] to the Secretary of the Smithsonian Institution, 1945-46. 12 pp. 1947.

Sixty-fourth annual report of the Bureau of American Ethnology [M. W. Stirling, Director] to the Secretary of the Smithsonian Institution, 1946-47. $30 \mathrm{pp}$. 1948. Out of print.

Sixty-fifth annual report of the Bureau of American Ethnology [M. W. Stirling, Director] to the Secretary of the Smithsonian Institution, 1947-48. $32 \mathrm{pp.}$ 1949. Out of print.

Sixty-sixth annual report of the Bureau of American Ethnology [M. W. Stirling, Director] to the Secretary of the Smithsonian Institution, 1948-49. $34 \mathrm{pp.}$ 1950. Out of print.

Sixty-seventh annual report of the Bureau of American Ethnology [M. W. Stirling, Director] to the Secretary of the Smithsonian Institution, 1949-50. $25 \mathrm{pp} .1951$. Out of print.

Sixty-eighth annual report of the Bureau of American Ethnology [M. W. Stirling, Director] to the Secretary of the Smithsonian Institution, 1950-51. $40 \mathrm{pp}$. 1952. Out of print.

Sixty-ninth annual report of the Bureau of American Ethnology [M. W. Stirling, Director] to the Secretary of the Smithsonian Institution, 1951-52. $30 \mathrm{pp}$. 1953. Out of print. 
Seventieth annual report of the Bureau of American Ethnology [M. W. Stirling, Director] to the Secretary of the Smithsonian Institution, 1952-53. $33 \mathrm{pp}$. 1954. Out of print.

Seventy-first annual report of the Bureau of American Ethnology [M.

W. Stirling, Director] to the Secretary of the Smithsonian Institution, 1953-54. 17 pp. 1955. Out of print.

Seventy-second annual report of the Bureau of American Ethnology [M. W. Stirling, Director] to the Secretary of the Smithsonian Institution, 1954-55. 24 pp. 1956 . Out of print.

Seventy-third annual report of the Bureau of American Ethnology [M. W. Stirling, Director] to the Secretary of the Smithsonian Institution, 1955-56. 23 pp. 1957.

Seventy-fourth annual report of the Bureau of American Ethnology [M. W. Stirling, Director] to the Secretary of the Smithsonian Institution, 1956-57. 28 pp. 1958.

Seventy-fifth annual report of the Bureau of American Ethnology

[Frank H. H. Roberts, Jr., Director] to the Secretary of the Smithsonian Institution, 1957-58. 36 pp. 1959.

Seventy-sixth annual report of the Bureau of American Ethnology [Frank H. H. Roberts, Jr., Director] to the Secretary of the Smithsonian Institution, 1958-59. 41 pp. 1960.

Seventy-seventh annual report of the Bureau of American Ethnology [Frank H. H. Roberts, Jr., Director] to the Secretary of the Smithsonian Institution, 1959-60. 35 pp. 1961.

\section{BULLETINS}

(In octavo form)

1. Bibliography of the Eskimo language, by James Constantine Pilling. v+116 pp. (incl. 8 pp. facsimiles). 1887. Out of print.

2. Perforated stones from California, by Henry W. Henshaw. 34 pp., 16 figs. 1887. Out of print.

3. The use of gold and other metals among the ancient inhabitants of Chiriqui, Isthmus of Darien, by William H. Holmes. 27 pp., 22 figs. 1887. Out of print.

4. Work in mound exploration of the Bureau of Ethnology, by Cyrus Thomas. 15 pp., 1 fig. 1887. Out of print.

5. Bibliography of the Siouan languages, by James Constantine Pilling. v+87 pp. 1887. Out of print. 
6. Bibliography of the Iroquoian languages, by James Constantine Pilling. vi $+208 \mathrm{pp}$. (incl. $4 \mathrm{pp}$. facsimiles), 5 unnumbered facsimiles. 1888 [1889]. Out of print.

7. Textile fabrics of ancient Peru, by William H. Holmes. 17 pp., 11 figs. 1889. Out of print.

8. The problem of the Ohio mounds, by Cyrus Thomas. 54 pp., 8 figs. 1889. Out of print.

9. Bibliography of the Muskhogean languages, by James Constantine Pilling. $\mathrm{v}+114 \mathrm{pp}$. 1889. Out of print.

10. The circular, square, and octagonal earthworks of Ohio, by Cyrus Thomas. 35 pp., 11 pls., 5 figs. 1889. Out of print.

11. Omaha and Ponka letters, by James Owen Dorsey. 127 pp. 1891. Out of print.

12. Catalogue of prehistoric works east of the Rocky Mountains, by Cyrus Thomas. 246 pp., 17 pls. (all maps). 1891. Out of print.

13. Bibliography of the Algonquian languages, by James Constantine Pilling. $x+614$ pp., 82 facsimiles. [Bibliographic notes on Eliot's Indian Bible and other works, pp. 127-184, 21 pls.] 1891 [1892]. Out of print.

[In separate form:] Bibliographic notes on Eliot's Indian Bible and on his other translations and works in the Indian language of Massachusetts. $4^{\circ}$. 60 pp., 21 pls. (facsimiles). 1890. Out of print.

14. Bibliography of the Athapascan languages, by James Constantine Pilling. xIII+125 pp. (incl. $4 \mathrm{pp}$. facsimiles). 1892. Out of print.

15. Bibliography of the Chinookan languages (including the Chinook jargon), by James Constantine Pilling. $x I I I+81$ pp. (incl. 3 facsimiles). 1893. Out of print.

16. Bibliography of the Salishan languages, by James Constantine Pilling. XIII +86 pp. (incl. 4 pp. facsimiles). 1893. Out of print.

17. The Pamunkey Indians of Virginia, by Jno. Garland Pollard. Preface by W J McGee. 19 pp. 1894. Out of print.

18. The Maya year, by Cyrus Thomas. Prefatory note by W J McGee. 64 pp., 1 pl. 1894. Out of print.

19. Bibliography of the Wakashan languages, by James Constantine Pilling. $\mathrm{xI}+70 \mathrm{pp}$. (incl. $2 \mathrm{pp}$. facsimiles). 1894. Out of print.

20. Chinook texts, by Franz Boas. 278 pp., 1 pl. 1894 [1895]. Out of print.

21. An ancient quarry in Indian Territory, by William Henry Holmes. 19 pp., 12 pls., 7 figs. 1894. Out of print. 
22. The Siouan tribes of the East, by James Mooney. 101 pp., map. 1894 [1895]. Out of print.

23. Archeologic investigations in James and Potomac Valleys, by Gerard Fowke. 80 pp., 17 figs. 1894 [1895]. Out of print.

24. List of the publications of the Bureau of Ethnology, with index to authors and subjects, by Frederick Webb Hodge. $25 \mathrm{pp}$. 1894. Out of print.

25. Natick dictionary, by James Hammond Trumbull. [With introduction by Edward Everett Hale, pp. Ix-xIII.] xxvIII+349 pp. 1903. Out of print.

26. Kathlamet texts, by Franz Boas. 261 pp., 1 pl. 1901.

27. 'Tsimshian texts, by Franz Boas. 244 pp. 1902.

28. Mexican and Central American antiquities, calendar systems, and history: Twenty-four papers by Eduard Seler, E. Förstemann, Paul Schellhas, Carl Sapper, and E. P. Dieseldorff. Translated from the German under the supervision of Charles P. Bowditch. 682 pp., 49 pls., 134 figs. 1904. Out of print.

29. Haida texts and myths: Skidegate dialect, by John R. Swanton. 448 pp., 5 figs. 1905. Out of print.

30. Handbook of American Indians north of Mexico, edited by Frederick Webb Hodge. Pt. 1, Ix +972 pp., many figures, map. 1907. Pt. 2, IV+1221 pp., many figures. 1910. Out of print.

Reprinted, January 1913, by Concurrent Resolution of August 12,$1912 ; 6,000$ copies for the use of Congress and 500 copies for distribution by the Bureau. Out of print. [Reprinted by Pageant Book Co., New York, 1959.]

31. List of publications of the Bureau of American Ethnology, with index to authors and titles. $31 \mathrm{pp}$. 1906. Out of print.

32. Antiquities of the Jemez Plateau, New Mexico, by Edgar L. Hewett. 55 pp., 17 pls. (incl. 1 map), 31 figs. 1906. Out of print.

33. Skeletal remains suggesting or attributed to early man in North America, by Aleš Hrdlička. [Prefatory note by W. H. Holmes.] 113 pp., 21 pls., 16 figs. 1907 . Out of print.

34. Physiological and medical observations among the Indians of southwestern United States and northern Mexico, by Aleš Hrdlička. IX +460 pp., 28 pls., 2 figs. 1908. Out of print.

35. Antiquities of the upper Gila and Salt River valleys in Arizona and New Mexico, by Walter Hough. 96 pp., 11 pls. (incl. 1 map), 51 figs. 1907. Out of print.

36. List of publications of the Bureau of American Ethnology, with index to authors and titles. $31 \mathrm{pp} .1907$. Out of print. 
37. Antiquities of central and southeastern Missouri, by Gerard Fowke. (Report on explorations made in 1906-7 under the auspices of the Archaeological Institute of America.) [With Report on skeletal material from Missouri Mounds, collected in 1906-07 by Mr. Gerard Fowke, by Aleš Hrdlička, pp. 103112.] VII +116 pp., 19 pls., 20 figs. 1910. Out of print.

38. Unwritten literature of Hawaii. The sacred songs of the hula collected and translated, with notes, and an account of the hula, by Nathaniel B. Emerson, A.M., M.D. [Prefatory note by W. H. Holmes.] 288 pp., 24 pls., 3 figs., 14 musical pieces. 1909. Out of print.

39. Tlingit myths and texts, recorded by John R. Swanton, viII +451 pp. 1909. Out of print.

40. Handbook of American Indian languages, by Franz Boas. Pt. 1, viI +1069 pp. Pt. 2, v+903 pp. Pt. 1, 1911. [Reprinted 1917.] Pt. 2, 1922. (Pt. 3, ed. by Franz Boas. Published by J. J. Augustin, New York: separates, 1933-38; volume, 1938.) Out of print.

Part 1: Introduction, by Franz Boas; Athapascan (Hupa), by Pliny Earle Goddard; Tlingit, Haida, by John R. Swanton; Tsimshian, Kwakiutl, Chinook, by Franz Boas; Maidu, by Roland B. Dixon; Algonquian (Fox), by William Jones (revised by Truman Michelson); Siouan (Dakota), by Franz Boas and John R. Swanton; Eskimo, by William Thalbitzer.

Part 2: Takelma, by Edward Sapir; Coos, by Leo J. Frachtenberg; Siuslawan, by Leo J. Frachtenberg; Chukchee, by Waldemar Bogoras.

41. Antiquities of the Mesa Verde National Park: Spruce-tree House, by J. Walter Fewkes. vin +57 pp., 21 pls., 37 figs. 1909. Out of print.

42. Tuberculosis among certain Indian tribes of the United States, by Aleš Hrdlička. viI +48 pp., 22 pls. 1909. Out of print.

43. Indian tribes of the lower Mississippi Valley and adjacent coast of the Gulf of Mexico, by John R. Swanton. viI +387 pp., 32 pls. (incl. $1 \mathrm{map}$ ), 2 figs. 1911. Out of print.

44. Indian languages of Mexico and Central America, and their geographical distribution, by Cyrus Thomas, assisted by John R. Swanton. Accompanied with a linguistic map. [Prefatory note by W. H. Holmes.] vir +108 pp., 1 map. 1911. Out of print.

45. Chippewa music, by Frances Densmore. xix +216 pp., 12 pls., 8 figs., 200 songs. 1910. Out of print.

46. A dictionary of the Choctaw language, by Cyrus Byington, edited by John R. Swanton and Henry S. Halbert. xI +611 pp., 1 pl. 1915. (Reprinted 1918.) Out of print. 
47. A dictionary of the Biloxi and Ofo languages, accompanied with thirty-one Biloxi texts and numerous Biloxi phrases, by James Owen Dorsey and John R. Swanton. v+340 pp. 1912. (Reprinted 1916.) Out of print.

48. The Choctaw of Bayou Lacomb, St. Tammany Parish, Louisiana, by David I. Bushnell, Jr. IX +37 pp., 22 pls., 1 fig. 1909. (Reprinted 1917.) Out of print.

49. List of publications of the Bureau of American Ethnology, with index to authors and titles. $32 \mathrm{pp} .1910$. Out of print. (Second impression 1911, $34 \mathrm{pp}$. Out of print.)

50. Preliminary report on a visit to the Navaho National Monument, Arizona, by Jesse Walter Fewkes. vir +35 pp., 22 pls., 3 figs. 1911. Out of print.

51. Antiquities of the Mesa Verde National Park: Cliff Palace, by Jesse Walter Fewkes. 82 pp., 35 pls., 4 figs. 1911. Out of print.

52. Early man in South America, by Aleš Hrdlička in collaboration with William H. Holmes, Bailey Willis, Fred. Eugene Wright, and Clarence N. Fenner. xv+405 pp., 68 pls., 51 figs. 1912. Out of print.

53. Chippewa music-II, by Frances Densmore. xxI +341 pp., 45 pls., 6 figs., 180 songs. 1913. Out of print.

54. The physiography of the Rio Grande Valley, New Mexico, in relation to Pueblo culture, by Edgar Lee Hewett, Junius Henderson, and Wilfred William Robbins. 76 pp., 11 pls., 2 figs. 1913. Out of print.

The Rio Grande Valley, New Mexico, by Edgar Lee Hewett. Pp. 1122. Geology and topography of the Rio Grande region in New Mexico, by Junius Henderson. Pp. 23-39.

Climate and evidence of climatic changes, by Junius Henderson and Wilfred William Robbins. Pp. 41-76.

55. Ethnobotany of the Tewa Indians, by Wilfred William Robbins, John Peabody Harrington, and Barbara Freire-Marreco. XII+124 pp., 9 pls., 7 figs. 1916. Out of print.

56. Ethnozoology of the Tewa Indians, by Junius Henderson and John Peabody Harrington. $\mathrm{x}+76 \mathrm{pp} .1914$.

57. An introduction to the study of the Maya hieroglyphs, by Sylvanus Griswold Morley. xvi 284 pp., 32 pls., 85 figs. 1915. Out of print.

58. List of publications of the Bureau of American Ethnology, with index to authors and titles. $39 \mathrm{pp} .1914$. Out of print.

59. Kutenai tales, by Franz Boas; together with texts collected by Alexander Francis Chamberlain. $x I I+387$ pp. 1918. Out of print. 
60. Handbook of aboriginal American antiquities. Part I. Introductory: The lithic industries, by W. H. Holmes. xvin +380 pp., 223 figs. 1919. Out of print.

61. Teton Sioux music, by Frances Densmore. xxvin+561 pp., 82 pls., 43 figs., 240 songs. 1918. Out of print.

62. Physical anthropology of the Lenape or Delawares, and of the Eastern Indians in general, by Aleš Hrdlička. 130 pp., 29 pls., 1 fig. 1916. Out of print.

63. Analytical and critical bibliography of the tribes of Tierra del Fuego and adjacent territory, by John M. Cooper. Ix +233 pp., 1 pl. (map). 1917. Out of print.

64. The Maya Indians of southern Yucatan and northern British Honduras, by Thomas W. F. Gann. 146 pp., 28 pls., 84 figs. 1918. Out of print.

65. Archeological explorations in northeastern Arizona, by Alfred Vincent Kidder and Samuel J. Guernsey. 228 pp., 97 pls., 102 figs. 1919. Out of print.

66. Recent discoveries attributed to early man in America, by Aleš Hrdlička. 67 pp., 14 pls., 8 figs. 1918. Out of print.

67. Alsea text and myths, by Leo J. Frachtenberg. 304 pp. 1920. Out of print.

68. A structural and lexical comparison of the Tunica, Chitimacha, and Atakapa languages, by John R. Swanton. 56 pp. 1919. Out of print.

69. Native villages and village sites east of the Mississippi, by David I. Bushnell, Jr. 111 pp., 17 pls., 12 figs. 1919. Out of print.

70. Prehistoric villages, castles, and towers of southwestern Colorado, by J. Walter Fewkes. 79 pp., 33 pls., 18 figs. 1919. Out of print.

71. Native cemeteries and forms of burial east of the Mississippi, by David I. Bushncll, Jr. 160 pp., 17 pls., 17 figs. 1920. Out of print.

72. The owl sacred pack of the Fox Indians, by Truman Michelson. 83 pp., 4 pls. 1921. Out of print.

73. Early history of the Creek Indians and their neighbors, by John R. Swanton. 492 pp., 10 pls. (all pocket maps). 1922. Out of print.

74. Excavation of a site at Santiago Ahuitzotla, D. F. Mexico, by Alfred M. Tozzer. 56 pp., 19 pls., 9 figs. 1921. Out of print.

75. Northern Ute music, by Frances Densmore. 213 pp., 16 pls., 21 figs., 110 songs. 1922. Out of print.

76. Archeological investigations. I. Cave explorations in the Ozark region of Central Missouri. II. Cave explorations in other 
States. III. Explorations along the Missouri River bluffs in Kansas and Nebraska. IV. Aboriginal house mounds. V. Archeological work in Hawaii. By Gerald Fowke. 204 pp., 45 pls., 37 figs. 1922. Out of print.

77. Villages of the Algonquian, Siouan, and Caddoan tribes west of the Mississippi, by David I. Bushnell, Jr. $\mathrm{x}+211$ pp., 55 pls., 12 figs. 1922. Out of print.

78. Handbook of the Indians of California, by A. L. Kroeber. xviri +995 pp. 83 pls. (incl. 1 pocket map), 78 figs. 1925. Out of print. [Reprinted by California Book Co., Lid., Berkeley, Calif.]

79. Blood revenge, war, and victory feasts among the Jibaro Indians of Eastern Ecuador, by Rafael Karsten. vir +94 pp., 10 pls. 1923. Out of print.

80. Mandan and Hidatsa music, by Frances Densmore. $x x+192$ pp., 19 pls., 6 figs., 110 songs. 1923. Out of print.

81. Excavations in the Chama Valley, New Mexico, by J. $\Lambda$. Jeancon. $\mathrm{rx}+80 \mathrm{pp} ., 65$ pls., 38 figs. 1923. Out of print.

82. Archeological observations north of the Rio Colorado, by Neil M. Judd. Ix+171 pp., 61 pls., 46 figs. 1926. Out of print. 83. Burials of the Algonquian, Sioun, and Caddoan tribes west of the Mississippi, by David I. Bushnell, Jr. $x+103$ pp., 37 pls., 3 figs. 1927. Out of print.

84. Vocabulary of the Kiowa language, by John P. Harrington. $\mathrm{v}+255$ pp., 1 fig. 1928.

85. Contributions to Fox ethnology: Notes on the ceremonial runners of the Fox Indians; a Sauk and Fox sacred pack; a sacred. pack called $\Lambda^{\prime}$ penäwänä'A belonging to the Thunder gens of the Fox Indians; a sacred pack called Sāgimā'kwäwA belonging to the Bear gens of the Fox Indians. By Truman Michelson. vir +168 pp., 2 pls., 2 figs. 1927. Out of print.

86. Chippewa customs, by Frances Densmore. XII +204 pp., 90 pls., 27 figs. 1929. Out of print.

87. Notes on the Buffalo-head dance of the Thunder gens of the Fox Indians, by Truman Michelson. $v+94$ pp., 1 fig. 1928.

88. Myths and tales of the Southeastern Indians, by John R. Swanton. $\mathrm{x}+275 \mathrm{pp}$. 1929 . Out of print.

89. Observations on the Thunder dance of the Bear gens of the Fox Indians, by Truman Michelson. v+73 pp., 1 fig. 1929. Out of print.

90. Papago music, by Frances Densmore. $\mathrm{xx}+229$ pp., 19 pls., 4 figs., 167 songs. 1929. Out of print.

91. Additional studies of the arts, crafts, and customs of the Guiana Indians, with special reference to those of southern British 
Guiana, by Walter E. Roth. xvII +110 pp., 34 pls., 90 figs. 1929. Out of print.

92. Shabik'eshchee village: A late Basket Maker site in the Chaco Canyon, New Mexico, by Frank H. H. Roberts, Jr. virI+164 pp., 31 pls., 32 figs. 1929. Out of print.

93. Pawnee music, by Frances Densmore. xvirt+129 pp., 8 pls., 86 songs. 1929. Out of print.

94. Tobacco among the Karuk Indians of California, by John P. Harrington. xxxvi +284 pp., 36 pls., 2 figs. 1932. Out of print.

95. Contributions to Fox ethnology-II, by Truman Michelson. vir +183 pp., 1 fig. 1930. Out of print.

96. Early Pueblo ruins in the Piedra district, southwestern Colorado, by Frank H. H. Roberts, Jr. Ix+190 pp., 55 pls., 40 figs. 1930. Out of print.

97. The Kamia of Imperial Valley, by E. W. Gifford. viI +94 pp., 2 pls., 4 figs. 1931. Out of print.

98. Tales of the Cochiti Indians, by Ruth Benedict. $x+256 \mathrm{pp}$. 1931. Out of print.

99. The Swimmer manuscript: Cherokee sacred formulas and medicinal prescriptions, by James Mooney; revised, completed, and edited by Frans M. Olbrechts. xvir +319 pp., 13 pls. 1932. Out of print.

100. The ruins at Kiatuthlanna, eastern Arizona, by Frank H. H. Roberts, Jr. virit195 pp., 47 pls., 31 figs. 1931. Out of print.

101. War ceremony and peace ceremony of the Osage Indians, by Francis La Flesche. vir +280 pp., 13 pls., 1 fig. 1939. Out of print.

102. Menominee music, by Frances Densmore. xxII +230 pp., 27 pls., 3 figs., 140 songs. 1932. Out of print.

103. Source material for the social and ceremonial life of the Choctaw Indians, by John R. Swanton. viI +282 pp., 6 pls., 1 fig. 1931. Out of print.

104. $\Lambda$ survey of prehistoric sites in the region of Flagstafi, Arizona, by Harold S. Colton. viI +69 pp., 10 pls. (incl. 4 maps), 21 figs. 1932. Out of print.

105. Notes on the Fox Wâpanōwiweni, by Truman Michelson. v+195 pp., 1 fig. 1932. Out of print.

106. Ethnographical survey of the Miskito and Sumu Indians of Honduras and Nicaragua, by Eduard Conzemius. vII +191 pp., 10 pls., 1 fig. 1932. Out of print.

107. Karuk Indian myths, by John P. Harrington. v+34 pp. 1932.

Out of print. 
108. A dictionary of the Atakapa language, accompanied by text material, by Albert S. Gatschet and John R. Swanton. v +181 pp., 1 pl. 1932.

109. A dictionary of the Osage language, by Francis La Flesche. v+406 pp. 1932. Out of print.

110. Yuman and Yaqui music, by Frances Densmore. xvin +216 pp., 31 pls., 7 figs., 130 songs. 1932 . Out of print.

111. The village of the Great Kivas on the Zuñi Reservation, New Mexico, by Frank H. H. Roberts, Jr. $1 x+197$ pp., 64 pls., 34 figs. 1932. Out of print.

112. An introduction to Pawnee archeology, by Waldo Rudolph Wedel. $\mathrm{xI}+122$ pp., 12 pls., 10 maps, 12 figs. 1936. Out of print.

113. The Troyville mounds, Catahoula Parish, La., by Winslow M.

Walker. vir +73 pp., 16 pls., 15 figs. 1936. Out of print.

114. Fox miscellany, by Truman Michelson. $\mathrm{v}+124$ pp., 9 figs. 1937. Out of print.

115. Journal of Rudolph Friederich Kurz. Translated by Myrtis Jarrell. Edited by J. N. B. Hewitt. Ix +382 pp., 48 pls. 1937. Out of print.

116. Ancient caves of the Great Salt Lake region, by Julian H. Steward. xiv +131 pp., 9 pls., 1 map, 48 figs. 1937. Out of print. 117. Historical and ethnographical material on the Jivaro Indians, by M. W. Stirling. $\quad$ xi +148 pp., 37 pls., 1 map, 6 figs. 1938. Out of print.

118. An archaeological survey of the Norris Basin in eastern Tennessee, by William S. Webb. xv+398 pp., 152 pls., 2 maps, 79 figs. 1938. Out of print.

119. Anthropological papers, numbers 1-6. $\mathrm{Ix}+204$ pp., 12 pls., 7 figs. 1938. Out of print.

No. 1. A preliminary report on archeological explorations at Macon, Ga., by A. R. Kelly. Pp. v-IX+1-68, pls. 1-12, figs. 1-7.

No. 2. The northern Arapaho flat pipe and the ceremony of covering the pipe, by John G. Carter. Pp. 69-102, figs. 8-10.

No. 3. The Caribs of Dominica, by Douglas Taylor. Pp. 103-159, pls. 13-18, figs. 11-37.

No. 4. What happened to Green Bear who was blessed with a sacred pack, by Truman Michelson. Pp. 161-176.

No. 5. Lemhi Shoshoni physical therapy, by Julian H. Steward. Pp. 177-181.

No. 6. Panatübiji', an Owens Valley Paiute, by Julian H. Steward. Pp. 183-195.

Papers available in separate form.

Nore.-With this bulletin the Bureau of American Ethnology inaugurated a new series of Anthropologieal Papers, designed as an outlet for brlef articles. These papers are numbered consecutively, a bulletin being devoted to them from time to time as they accumulate. A limited edition of Anthropological Papers Is issued in separate form. 
120. Basin-plateau aboriginal sociopolitical groups, by Julian H. Steward. xiI +346 pp., 3 pls., 13 figs. 1938. Out of print. 121. Archeological remains in the Whitewater District, eastern Arizona. Part I: House types, by Frank H. H. Roberts, Jr. xir +276 pp., 30 pls., 53 figs. 1939 . Out of print.

122. An archaeological survey of Wheeler Basin on the Tennessee River in northern Alabama, by William S. Webb. xv+214 pp., 122 pls., 2 maps, 25 figs. 1939 . Out of print.

123. Anthropological papers, numbers 7-12. viI +305 pp., 32 pls., 27 figs. 1939. Out of print.

No. 7. Archeological investigations in the Corozal District of British Honduras, by Thomas and Mary Gann. [Incl. Report on two skulls from British Honduras, by A. J. E. Cave, pp. 59-60]. viI-viII $+1-66$, pls. $1-10$, figs. $1-11$.

No. 8. Linguistic classification of Cree and Montagnais-Naskapi dialects, by Truman Michelson. Pp. 67-95, fig. 12.

No. 9. Sedelmayr's Relacion of 1746 , translated and edited by Ronald L. Ives. Pp. 97-117.

No. 10. Notes on the Creek Indians, by J. N. B. Hewitt, edited by John R. Swanton. Pp. 119-159, figs. 13-14.

No. 11. The Yaruros of the Capanaparo River, Venezuela, by Vincenzo Petrullo. Pp. 161-290, pls. 11-25, figs. 15-27.

No. 12. Archeology of Arauquin, by Vincenzo Petrullo. Pp. 291-295, pls. 26-32.

Papers available in separate form.

124. Nootka and Quileute music, by Frances Densmore. xxvi +358 pp., 24 pls., 7 figs., 210 songs. 1939. Out of print.

125. Ethnography of the Fox Indians, by William Jones; edited by Margaret Welpley Fisher. 1x+156 pp. 1939. Out of print.

126. Archeological remains in the Whitewater District, eastern Arizona. Part II: Artifacts and burials, by Frank H. H. Roberts, Jr. With appendix, Skeletal remains from the Whitewater District, eastern Arizona, by 'T. D. Stewart. $\mathrm{xI}+170$ pp., 57 pls., 44 figs. 1940. Out of print.

127. Linguistic material from the tribes of southern 'Texas and northeastern Mexico, by John R. Stranton. v+145 pp. 1940. Out of print.

128. Anthropological papers, numbers $13-18$. $x I I+368$ pp., 52 pls., 77 figs. 1941. Out of print.

No. 13. The mining of gems and ornamental stones by American Indians, by Sydney H. Ball. Pp. IX-xiI +1-77, pls. 1-5.

No. 14. Iroquois suicide: A study in the stability of a culture pattern, by William N. Fenton. Pp. 79-137, pls. 6-8.

No. 15. Tonawanda longhouse ceremonies: Ninety years after Lewis Henry Morgan, by William N. Fenton. Pp. 139-165, pls. 9-18. 
No. 16. The Quichua-speaking Indians of the Province of Imbabura (Ecuador) and their anthropometric relations with the living populations of the Andean area, by John Gillin. Pp. 167-228, pls. 19-29, figs. 1-2.

No. 17. Art processes in birchbark of the River Desert Algonquin, a circumboreal trait, by Frank G. Speck. Pp. 229-274, pls. 30-42, figs. $3-25$.

No. 18. Archeological reconnaissance of southern Utah, by Julian II. Steward. Pp. 275-356, pls. 43-52, figs. 26-77.

Papers available in separate form.

129. An archeological survey of Pickwick Basin in the adjacent portions of the States of Alabama, Mississippi, and Tennessee. by William S. Webb and David L. DeJarnett. With additions by Walter B. Jones; J. P. E. Morrison; Marshall T. Newman and Charles E. Snow; and William G. Haag. xxII+536 pp., 316 pls., 2 maps, 99 figs. 1942. Out of print.

Geology of the Pickwick Basin, in adjacent parts of Tennessee, Mississippi, and Alabama, by Walter B. Jones. Pp. 327-335.

Preliminary report on mollusks found in the shell mounds of the Pickwick Landing Basin in the Tennessee River Valley by J. P. E. Morrison. Pp. 337-392.

Preliminary report on the skeletal material from Pickwick Basin, Alabama, by Marshall T. Newman and Charles E. Snow. Pp. 393-507.

A description and analysis of the Pickwick pottery, by William G. Haag. Pp. 509-526.

130. Archeological investigations at Buena Vista Lake, Kern County, California, by Waldo R. Wedel. With appendix, Skeletal remains from the Buena Vista sites, California, by T. D. Stewart. viII +194 pp., 57 pls., 19 figs. 1941. Out of print.

131. Peachtree Mound and village site, Cherokee County, North Carolina, by Frank M. Setzler and Jesse D. Jennings. With appendix, Skeletal remains from the Peachtree Site, North Carolina, by T. D. Stewart. Ix+103 pp., 50 pls., 12 figs. 1941. Out of print.

132. Source material on the history and ethnology of the Caddo Indians, by John R. Swanton. vir +332 pp., 19 pls., 5 figs. 1942. Out of print.

133. Anthropological papers, numbers 19-26. Ix +615 pp., 34 pls., 62 figs. 1943 [1944]. Out of print.

No. 19. A search for songs among the Chitimacha Indians in Louisiana, by Frances Densmore. Pp. 1-15, pls. 1-4.

No. 20. Archeological survey on the northern Northwest Coast, by Philip Drucker. With appendix, Early vertebrate fauna of the British Columbia coast, by Edna M. Fisher. Pp. 17-142, pls. 5-9, figs. 1-33. Out of print. 
No. 21. Some notes on a few sites in Beaufort County, South Carolina, by Regina Flannery. Pp. 143-153, figs. 34-35.

No. 22. An analysis and interpretation of the ceramic remains from two sites near Beaufort, South Carolina, by James B. Griffin. Pp. 155-168, pls. 10-12.

No. 23. The Eastern Cherokees, by William Harlen Gilbert, Jr. Pp. 169-413, pls. 13-17, figs. 36-55. Out of print.

No. 24. Aconite poison whaling in Asia and America: An Aleutian transfer to the New World, by Robert F. Heizer. Pp. 415-468, pls. 18-23A, figs. 56-60.

No. 25. The Carrier Indians of the Bulkley River: Their social and religious life, by Diamond Jenness. Pp. 469-586, pls. 24-34, figs. 61-62.

No. 26. The quipu and Peruvian civilization, by John R. Swanton. Pp. 587-596.

Papers available in separate form.

134. The native tribes of eastern Bolivia and western Matto Grosso, by Alfred Métraux. Ix+182 pp., 5 pls., 1 fig. 1942. Out of print.

135. Origin myth of Acoma and other records, by Matthew IV. Stirling. viII+123 pp., 17 pls., 8 figs. 1942. Out of print. 136. Anthropological papers, numbers $27-32$. viI +375 pp., 32 pls., 5 figs. 1943 [1944]. Out of print.

No. 27. Music of the Indians of British Columbia, by Frances Densmore. Pp. 1-99, pls. 1-9, figs. 1-2, 98 songs.

No. 28. Choctaw music, by Frances Densmore. Pp. 101-188, pls. 10-21, figs. 3-4, 65 songs. Out of print.

No. 29. Some ethnological data concerning one hundred Yucatan plants, by Morris Steggerda. Pp. 189-226, pls. 22-24.

No. 30. A description of thirty towns in Yucatan, Mexico, by Morris Steggerda. Pp. 227-248, pls. 25-28. Out of print.

No. 31. Some western Shoshoni myths, by Julian H. Steward. Pp. 249-299. Out of print.

No. 32. New material from Acoma, by Leslie A. White. Pp. 301-359, pls. 29-32, fig. 5 .

Papers available in separate form.

137. The Indians of the Southeastern United States, by John R. Swanton. xint943 pp., 107 pls., 5 figs., 13 maps. 1946. Out of print.

138. Stone monuments of southern Mexico, by Matthew W. Stirling. vir +84 pp., 62 pls., 14 figs. 1943 [1944].

139. An introduction to the ceramics of Tres Zapotes, Feracruz, Mexico, by C. W. Weiant. xiv +144 pp., 78 pls., 54 figs., 10 maps. 1943.

140. Ceramic sequences at Tres Zapotes, Veracruz, Mexico, by Philip Drucker. IX +155 pp., 65 pls., 46 figs. 1943. 
141. Ceramic stratigraphy at Cerro de las Mesas, Veracruz, Mexico, by Philip Drucker. viII +95 pp., 58 pls., 210 figs. 1943 [1944].

142. The contemporary culture of the Cáhita Indians, by Ralph L.

Beals. XII +244 pp., 20 pls., 33 figs., 1 map. 1945.

143. Handbook of South American Indians. Julian H. Steward, editor. 7 vols. (Vols. $1-2,1946 ; 3-4,1948 ; 5,1949 ; 6,1950$; 7 (Index), 1959).

Volume 1. The Marginal tribes. $\mathrm{xrx}+624$ pp., 112 pls., 69 figs., 7 maps. 1946. Out of print.

Part 1. Indians of southern South America.

Introduction, by Julian H. Steward. Pp. 1-9.

The Southern Hunters, by John M. Cooper. Pp. 13-15, pls. 1-4.

The archeology of Patagonia, by Junius Bird. Pp. 17-24, pls. 5-12.

The archeology of the Greater Pampa, by Gordon R. Willey. Pp. 25-46, pls. 13-22, figs. 1-9.

The Chono, by John M. Cooper. Pp. 47-54.

The Alacaluf, by Junius Bird. Pp. 55-79, pls. 23-32, fig. 10.

The Yahgan, by John M. Cooper. Pp. 81-106, figs. 11-14.

The Ona, by John M. Cooper. Pp. 107-125, figs. 15-17.

The Patagonian and Pampean Hunters, by John M. Cooper Pp. 127-168, pls. 33-40, figs. 18-20.

The Huarpe, by Salvador Canals Frau. Pp. 169-175, figs. 21-22.

Indians of the Paraná Delta and La Plata Littoral, by S. K. Lothrop. Pp. 177-190, fig. 23.

The Charrua, by Antonio Serrano. Pp. 191-196, pls. 41-44. Part 2. Indians of the Gran Chaco.

Ethnography of the Chaco, by Alfred Métraux. Pp. 197-370, pls. 45-76, figs. 24-42, maps 4-5.

The present-day Indians of the Gran Chaco, by Juan Belaieff. Pp. 371-380.

Eastern Brazil: An introduction, by Robert H. Lowie. Pp. 381-397, map 7.

Lagoa Santa Man, by Annibal Mattos. Pp. 399-400.

The sambaquís of the Brazilian coast, by Antonio Serrano. Pp. 401-407, pls. 77-80, figs. 43-46, map 6.

The Guato, by Alfred Métraux. Pp. 409-418, pls. 81-82, figs. $47-50$.

The Bororo, by Robert H. Lowie. Pp. 419-434, pls. 83-94, figs. 51-55.

Guayakí, by Alfred Métraux and Herbert Baldus. Pp. 435444, pls. 95-96.

The Caingang, by Alfred Métraux. Pp. 445-475, figs. 56-60.

The Northwestern and Central Ge, by Robert H. Lowie. Pp. 477-517, pls. 97-104, figs. 61-67.

The Southern Cayapó, by Robert H. Lowie. Pp. 519-520.

The Guaitacá, by Alfred Métraux. Pp. 521-522.

The Puri-Coroado linguistic family, by Alfred Métraux. Pp. $522-530$, fig. 68. 
The Botocudo, by Alfred Métraux. Pp. 531-540.

The Mashacali, Patasho, and Malali linguistic families, by Alfred Métraux. Pp. 541-545.

The Camacan linguistic family, by Alfred Métraux and Curt Nimuendajú. Pp. 547-552.

The "Tapuya," by Robert H. Lowie. Pp. 553-556, fig. 69.

The Cariri, by Robert H. Lowie. Pp. 557-559.

The Pancararú, by Robert H. Lowie. P. 561 .

The Tarairiu, by Robert H. Lowie. Pp. 563-566.

The Jeico, by Robert H. Lowie. P. 567.

The Guck, by Robert H. Lowie. P. 569.

The Fulnio, by Alfred Métraux. P. 571.

The Teremembé, by Alfred Métraux. Pp. 573-574.

(Followed by pls. 105-112, illustrating various Indian tribes described in preceding papers.)

Bibliography to Volume 1. Pp. 575-624.

Volume 2. The Andean civilizations. xxxıv + 1035 pp., 192 pls., 100

figs., 11 maps. 1946. Out of print.

Preface, by Julian H. Steward. Pp. xxv-xxxr. Map. 1.

Part 1. The Andean Highlands: An introduction, by Wendell C.

Bennett. Pp. 1-60, pls. 1-16.

Part 2. The Central Andes.

The archeology of the Central Andes, by Wendell C. Bennett. Pp. 61-147, pls. 17-60, figs. 1-18, map 2.

A culture sequence for the North Coast of Perú, by Rafael Larco Hoyle. Pp. 149-175, pls. 61-72, figs. 20-22.

Cuzco archeology, by Luis E. Valcárcel. Pp. 177-182, pls. 73-76.

Inca culture at the time of the Spanish conquest, by John Howland Rowe. Pp. 183-330, pls. 77-84, figs. 23-29, maps 3,4 .

The Quechua in the Colonial world, by George Kubler. Pp. 331-410, pls. 85-92, figs. 39-43.

The contemporary Quechua, by Bernard Mishkin. Pp. 411470, pls. $93-100$.

The Andean calendar, by Luis E. Valcárcel. Pp. 471-476.

Indian markets and fairs in Perú, by Luis E. Valcárcel. Pp. 477-482.

Social and economico-political evolution of the communities of Central Perú, by Hildebrando Castro Pozo. Pp. 483499.

The Aymara, by Harry Tschopik, Jr. Pp. 501-573, pls. 101-112, figs. 44-48.

The Uru-Chipaya, by Weston La Barre. Pp. 575-585, pls. 113-120.

Part 3. The Southern Andes.

The cultural sequence of the North Chilean Coast, by Junius B. Bird. Pp. 587-594, pls. 121-128, fig. 49.

The historic inhabitants of the North Chilean Coast, by Junius B. Bird. Pp. 595-597.

The Atacameño, by Wendell C. Bennett. Pp. 599-618, pls. 129-134. 
The cultures of the Puna and the Quebrada of Humahuaca, by Eduardo Casanova. Pp. 619-631, pls. 135-138, figs. 50-58.

The Diaguita of Chile, by Samuel K. Lothrop. Pp. 633-636, pls. 139-140.

The Diaguita of Argentina, by Fernando Márquez Miranda. Pp. 637-654, pls. 141-146, figs. 59-63, map 5.

The Chaco-Santiagueño culture, by Fernando Márquez Miranda. Pp. 655-660, pls. 147-148.

The culture of La Candelaria, by Gordon R. Willey. Pp. 661672, figs. 64-68.

The Comechingon and their neighbors of the Sierras de Córdoba, by Francisco de Aparicio. Pp. 673-685, pls. 149-152, figs. 69-70.

The Araucanians, by John M. Cooper. Pp. 687-760, pls. 153-156, figs. 71-85.

Expansion of the Araucanians in Argentina, by Salvador Canals Frau. Pp. 761-766.

Part 4. The Northern Andes.

The archeology of Ecuador, by Donald Collier. Pp. 767784, pls. 157-160, figs. 86-90, map 6.

The historic tribes of Ecuador, by John Murra. Pp. 785821, pls. 161-168, map 7.

The archeology of Colombia, by Wendell C. Bennett. Pp. 823-850, pls. 169-176, figs. 91-97, map 8.

The archeology of San Agustín and Tierradentro, Colombia, by Gregorio Hernández de Alba. Pp. 851-859, figs. 98-99.

The archeology of the Popayan region, Colombia, by Henri Lehmann. Pp. 861-864, fig. 100.

Tribes of the Sierra Nevada de Santa Marta, Colombia, by Willard Z. Park. Pp. 865-886, pls. 177-184.

The Chibcha, by A. L. Kroeber. Pp. 887-909, map 9.

The native tribes and languages of southwestern Colombia, by Sergio Elías Ortíz. Pp. 911-914, maps 10, 11.

The Highland tribes of southern Colombia, by Gregorio Hernández de Alba. Pp. 915-960, pls. 185-192.

The modern Quillacinga, Pasto, and Coaiquer, by Sergio Elías Ortíz. Pp. 961-968.

The Moguex-Coconuco, by Henri Lehmann. Pp. 969-974. Glossary. Pp. 975-978.

Bibliography to Volume 2. Pp. 979-1035.

Volume 3. The Tropical Forest tribes. xxvi +986 pp., 126 pls., 134 figs., 8 maps. 1948. Out of print.

Preface, by Julian H. Steward. Pp. xxI-xxiv. Map 1.

The tropical forests: An introduction, by Robert H. Lowie. Pp. $1-56$, pls. 1-8, figs. 1-3.

Part 1. The Coastal and Amazonian Tupí.

The archeology of the Paraná River, by Francisco de Aparicio. Pp. 57-67, pls. 9-10, figs. 3-4.

The Guarani, by Alfred Métraux. Pp. 69-94, pls. 11-12, fig. 5 . 
The Tupinamba, by Alfred Métraux. Pp. 95-133, figs. 6-15.

The Guajá, by Curt Nimuendajú. Pp. 135-136.

The Tenetehara, by Charles Wagley and Eduardo Galvão. Pp. 137-148, pls. 13-14.

The archeology of the Amazon Basin, by Betty J. Meggers.

Pp. 149-166, pls. 15-18, figs. 16-17, map 2.

The Tapirapé, by Charles Wagley and Eduardo Galvão. Pp. 167-178, pl. 19.

The Carajá, by William Lipkind. Pp. 179-191, pls. 20-22, figs. 18-24.

The Turiwara and Arua, by Curt Nimuendajú. Pp. 193198.

The Amanayé, by Curt Nimuendajú and Alfred Métraux. Pp. 199-202.

Little-known tribes of the lower Tocantins River region, by Curt Nimuendajú. Pp. 203-208.

Little-known tribes of the lower Amazon, by Curt Nimuendajú. Pp. 209-211.

Tribes of the lower and middle Xingú River, by Curt Nimuendajú. Pp. 213-243, figs. 25-31.

The Maué and Arapium, by Curt Nimuendajú. Pp. 245254.

The Mura and Pirahá, by Curt Nimuendajú. Pp. 255-269.

The Mundurucú, by Donald Horton. Pp. 271-282, pl. 23.

The Cawahib, Parintintin, and their neighbors, by Curt Nimuendajú. Pp. 283-297, map 3.

The Tupi-Cawahíb, by Claude Lévi-Strauss. Pp. 299-305, pls. 24-26.

The Cayabi, Tapanyuna, and Apiacá, by Curt Nimuendajú. Pp. 307-320.

The tribes of the upper Xingú River, by Claude Lévi-Strauss. Pp. 321-348, pls. 27-34, figs. 32-42.

Part 2. The tribes of Mato Grosso and eastern Bolivia.

The Paressí, by Alfred Métraux. Pp. 249-360, pl. 35, figs. 43-44.

The Nambicuara, by Claude Lévi-Strauss. Pp. 361-369, pls. 36-37.

Tribes of the right bank of the Guapore River, by Claude Lévi-Strauss. Pp. 371-379, pl. 38, figs. 45-48.

Tribes of eastern Bolivia and the Madeira headwaters, by Alfred Metraux. Pp. 381-454, pls. 39-40, figs. 49-56, map 4.

The Siriono, by Allan Holmberg. Pp. 455-463.

Tribes of the eastern slopes of the Bolivian Andes, by Alfred Métraux. Pp. 465-506, pls. 41-47, figs. 57-71.

Part 3. Tribes of the Montaña and Bolivian East Andes.

Tribes of the Montana: An introduction, by Julian $H$. Steward. Pp. 507-533, figs. 72-75, maps 5, 6.

Tribes of the Peruvian and Ecuadorian Montaña, by Julian H. Steward and Alfred Métraux. Pp. 535-656, pls. 48-63, figs. 76-93. 
Part 4. Tribes of the western Amazon Basin.

Tribes of the Juruá-Purús Basins, by Alfred Métraux. Pp. 657-686, figs. 94-101.

Tribes of the middle and upper Amazon River, by Alfred Métraux. Pp. 687-712, figs. 102-103.

The Tucuna, by Curt Nimuendajú. Pp. 713-725, pls. 64-65.

The Peban tribes, by Julian H. Steward and Alfred Métraux. Pp. 727-736, pls. 66-79.

Western Tucanoan tribes, by Julian H. Steward. Pp. 737748 , pl. 80.

The Witotoan tribes, by Julian H. Steward. Pp. 749-762, pls. 81-88, figs. 104-106.

Tribes of the Uaupés-Caquetá region, by Irving Goldman. Pp. 763-798, pls. 89-104, figs. 107-118.

Part 5. Tribes of the Guianas and the left Amazon tributaries.

Tribes of the Guianas, by John Gillin. Pp. 799-860, pls. 105-124, figs. 119-133, map 7.

The hunting and gathering tribes of the Rio Negro Basin, by Alfred Métraux. Pp. 861-867, pls. 125-126.

The Warrau, by Paul Kirchhoff. Pp. 869-881, fig. 134.

Part 6. Culture areas of the Tropical Forests, by Julian H.

Steward. Pp. 883-899, map 8.

Glossary. Pp. 901-902.

Bibliography to Volume 3. Pp. 903-986.

Volume 4. The Circum-Caribbean tribes. $\mathrm{xx}+609$ pp., 98 pls.,

79 figs., 11 maps. 1948. Out of print.

Preface, by Julian H. Steward. Pp. xv-xvir. Map 1.

The Circum-Caribbean tribes: An introduction, by Julian $\mathrm{H}$. Steward. Pp. 1-41.

Part 1. Central American cultures.

Central American cultures: An introduction, by Frederick Johnson. Pp. 43-68, map 2.

The archeology of Central America.

The archeology of Central America: An introduction, by Wm. Duncan Strong. Pp. 69-70.

The archeology of Honduras, by Wm. Duncan Strong. Pp. 71-120, pls. 1-12, figs. 1-15, map 3.

The archeology of Costa Rica and Nicaragua, by Wm. Dunean Strong. Pp. 121-142, pls. 13-18, figs. 16-26.

The archeology of Panamá, by Samuel IK. Lothrop. Pp. 143-167, pls. 19-20, figs. 27-47, map 4.

The basic cultures of Central America, by Doris Stone. Pp. 169-193, pls. 21-32.

The post-Conquest ethnology of Central America.

The post-Conquest ethnology of Central America: An introduction, by Frederick Johnson. Pp. 195-198, map 5.

The Meso-American Division, by Frederick Johnson. Pp. 199-204.

The northern Highland tribes: The Lenca, by Doris Stone. Pp. 205-217, pls. 33-34, figs. 48-49. 
The Caribbean Lowland tribes: The Mosquito, Sumo, Paya, and Jicaque, by Paul Kirchhoff. Pp. 219-229, pls. $35-36$.

The Caribbean Lowland tribes. The Talamanca Division, by Frederick Johnson. Pp. 231-251, pls. 37-38, figs. 50-57.

The tribes west and south of the Panama Canal, by Samuel K. Lothrop. Pp. 253-256.

The Cuna, by David B. Stout. Pp. 257-268, pls. 49-56, figs. 58-60.

The Choc6, by David B. Stout. Pp. 269-276, figs. 61-66.

The Cayapa and Colorado, by John Murra. Pp. 277291, pls. $57-60$.

Anthropological needs and possibilities in Central America, by Wm. Duncan Strong and Frederick Johnson. Pp. 293-296.

Part 2. The cultures of Northwest South America.

Sub-Andean tribes of the Cauca Valley, by Gregorio Hernández de Alba. Pp. 297-327.

Tribes of the North Colombia Lowlands, by Gregorio Hernández de Alba. Pp. 329-338.

Patángoro and Amaní, by Paul Kirchhoff. Pp. 339-348.

The northeastern extension of Andean culture, by Alfred

Métraux and Paul Kirchhoff. Pp. 349-368, pls. 61-71, fig. $67, \operatorname{map} 6$.

The Goajiro, by John M. Armstrong and Alfred Métraux. Pp. 369-383, pl. 72.

The Guayupé and Sae, by Paul Kirchhoff. Pp. 385-391.

The Betoi and their neighbors, by Gregorio Hernández de Alba. Pp. 393-398.

The Achagua and their neighbors, by Gregorio Hernández de Alba. Pp. 399-412.

The archeology of Venezuela, by Alfred Kidder II. Pp. 413-438, pls. 73-76, figs. 68-77, map 7 .

The Otomac, by Paul Kirchhoff. Pp. 439-444.

Food-gathering tribes of the Venezuelan Llanos, by Paul Kirchhoff. Pp. 445-468, pls. 77-78, figs. 78-79.

Tribes of northwestern Venezuela, by Gregorio Hernández de Alba. Pp. 469-474.

The tribes of North Central Venezuela, by Gregorio Hernández de Alba. Pp. 475-479.

The tribes north of the Orinoco River, by Paul Kirchhoff. Pp. 481-493.

Part 3. The West Indies.

The West Indies: An introduction, by Irving Rouse. Pp. 495-496.

The Ciboney, by Irving Rouse. Pp. 497-505, pls. 79-85, maps 8, 9. (Including "The Ethnography of the Ciboney," by Pedro García Valdes, pp. 503-505.)

The Arawak, by Irving Rouse. Pp. 507-546, pls. 86-92, maps 10, 11. (Including "The Ethnography of Puerto Rico," by Adolfo de Hostos, pp. 540-542.) 
The Carib, by Irving Rouse. Pp. 547-564, pls, 93-98.

Bibliography to Volume 4. Pp. 567-609.

Volume 5. The c mparative ethnology of South American Indians. xxvi +818 pp., 56 pls., 190 figs., 22 maps. 1949. Out of print.

Part 1. A cross-cultural survey of South American Indian tribes. Architecture and engineering.

Habitations, by Wendell C. Bennett. Pp. 1-20, pls. 1-3, figs. 1-4.

Household furniture, by Wendell C. Bennett. Pp. 21-27.

Religious structures, by Wendell C. Bennett. Pp. $29-51$, pls. 4-9, figs. 5-12.

Engineering, by Wendell C. Bennett. Pp. 53-65, pls. 10-16.

Manufactures and technology.

Bark cloth, by Alfred Métraux. Pp. 67-68.

Basketry, by Lila M. O'Neale. Pp. 69-96, pls. 17-23, figs. 13-25.

Weaving, by Lila M. O'Neale. Pp. 97-138, pls. 24-28, figs. 26-41.

Ceramies, by Gordon R. Willey. Pp. 139-204, pls. 29-40, figs. 42-63, maps 1-3.

Metallurgy, by William C. Root. Pp. 205-225.

Rubber, by Alfred Métraux. Pp. 227-228.

Weapons, by Alfred Métraux. Pp. 229-263, figs. 64-67, maps 4-6.

Traps, by John M. Cooper. Pp. 265-276, figs. 68-77, map 7.

Fish poisons, by Robert F. Heizer. Pp. 277-281.

Fire making, by John M. Cooper. Pp. 283-292, figs. 78-86, map 8.

Social and political life.

The social and political organization of the Andean peoples, by Paul Kirchhoff. Pp. 293-311.

Social and political organization of the Tropical Forest and Marginal tribes, by Robert H. Lowie. Pp. 313-350.

Property among the Tropical Forest and Marginal tribes, by Robert H. Lowie. Pp. 351-367.

The couvade, by Alfred Métraux. Pp. 369-374.

Boys' initiation rites, by Alfred Métraux. Pp. 375-382.

Warfare, cannibalism, and human trophies, by Alfred Métraux. Pp. 383-409.

Esthetic and recreational activities.

Art, by A. L. Kroeber. Pp. 411-492, pls. 41-48, figs. 87-160.

Petroglyphs, by Irving Rouse. Pp. 493-502, pls. 49-52, figs. 161-165.

Games and gambling, by John M. Cooper. Pp. 503-524, figs. 166-179.

Stimulants and narcoties, by John M. Cooper. Pp. 525-558, figs. 180-185, maps 9-15. 
Religion and shamanism, by Alfred Métraux. Pp. 559-599.

Lore and learning.

Numbers, measures, weights, and calendars, by Wendell C. Bennett. Pp. 601-610, fig. 186.

Mnemonic and recording devices, by Wendell C. Bennett. Pp. 611-619, pls. 53-54, fig. 187.

Medical practices, by Erwin $H$. Ackerknecht. Pp. 621-643, pls. 55-56, figs. 188-190.

Part 2. Jesuit missions in South America, by Alfred Métraux. Pp. 645-653.

Part 3. The native population of South America, by Julian H.

Steward. Pp. 655-668, maps 16-17.

Part 4. South American cultures: An interpretative summary,

by Julian H. Steward. Pp. 669-772, maps 18-22.

Glossary. Pp. 773-782.

Bibliography to Volume 5. Pp. 783-818.

Volume 6. Physical anthropology, linguistics, and cultural geography of South American Indians. XIII +715 pp., 47 pls., 3 figs., 18 maps. 1950. Out of print.

Preface, by Julian H. Steward. Pp. $\mathbf{x}-\mathbf{x} I$.

Part 1. Ancient man.

The antiquity of man in South America, by Theodore D. McCown. Pp. 1-9, pls. 1-2.

The present status of the theories concerning primitive man in Argentina, by Joaquín Frenguelli. Pp. 11-17, pls. 3-4, fig. 1.

Part 2. Physical anthropology. T. Dale Stewart, editor.

Skeletal remains of South American Indians.

Anthropometry of South American Indian skeletal remains, by $\mathrm{T}$. Dale Stewart and Marshall $\mathrm{T}$. Newman. Pp. 19-42, pls. 5-8, maps 1-3.

Deformity, trephining, and mutilation in South American Indian skeletal remains, by $T$. Dale Stewart. Pp. 43-48.

Pathological changes in South American Indian skeletal remains, by T. Dale Stewart. Pp. 49-52, pls. 9-12.

Cephalic deformations of the Indians in Argentina, by José Imbelloni. Pp. 53-55, pls. 13-14, fig. 2.

The living South American Indians.

Anthropometry of South American Indians, by Morris Steggerda. Pp. 57-69, pls. 15-22, maps 4-5.

The anthropometry of the Indians of Brazil, by José Bastos d'Avila. Pp. 71-84, pl. 23.

The pigmentation and hair of South American Indians, by Morris Steggerda. Pp. 85-90.

Blood groups of South American Indians, by William C. Boyd. Pp. 91-95, map 6.

The basal metabolic rates of South American Indians, by Elsie A. Wilson. Pp. 97-104. 
South American Mestizos.

Mestizos of South America, by Morris Steggerda. Pp. 105-109.

Brazilian Mestizo types, by Maria Julia Pourchet. Pp. 111-120.

The physical anthropology of Chile.

The anthropometry of the Indians of Chile, by Carlos Henckel. Pp. 121-135, pls. 24-27.

The geographical pathology of Chile, by Ernesto Herzog. Pp. 137-144.

The physical anthropology of the internal organs among the races of Chile, by Carlos Henckel. Pp. 145-156, fig. 3.

Glossary to Part 2.

Part 3. The languages of South American Indians, by J. Alden Mason. Pp. 157-317.

Part 4. Geography and plant and animal resources.

The geography of South America, by Carl O. Sauer. Pp. 319-344, pls. 28-35, maps 7-10.

Fauna and ethnozoology of South America, by Raymond

M. Gilmore. Pp. 345-464, pls. 36-47, maps 11-17.

The use of wild plants in tropical South America, by Claude Lévi-Strauss. Pp. 465-486.

Cultivated plants of South and Central America, by Carl O. Sauer. Pp. 487-543.

Bibliography to Volume 6. Pp. 545-715.

Volume 7. Index [to the 6 volumes of the Handbook]. $v i+286$. 1959.

144. The Northern and Central Nootkan tribes, by Philip Drucker. IX +480 pp., 5 pls., 28 figs., 8 maps. 1951.

145. The Indian tribes of North America, by John R. Swanton. vit 726 pp., 5 maps. 1952. Out of print.

146. Chippewa child life and its cultural background, by Sister M. Inez Hilger. $\quad$ xiv +204 pp., 31 pls., 1 fig. 1951.

147. Journal of an expedition to the Mauvaises Terres and the Upper Missouri in 1850, by Thaddeus A. Culbertson. Edited by John Francis McDermott. viII+164 pp., 2 maps. 1952.

148. Arapaho child life and its cultural background, by Sister M. Inez Hilger. $x v+253$ pp., 40 pls., 1 fig. 1952.

149. Symposium on local diversity in Iroquois culture, edited by William N. Fenton. v+187 pp., 21 figs. 1951.

No. 1. Introduction: The concept of locality and the program of Iroquois research, by William N. Fenton. Pp. 1-12.

No. 2. Concepts of land ownership among the Iroquois and their neighbors, by George S. Snyderman. Pp. 13-34.

No. 3. Locality as a basic factor in the development of Iroquois social structure, by William N. Fenton. Pp. 35-54.

No. 4. Some psychological determinants of culture change in an Iroquoian community, by Anthony F. C. Wallace. Pp. 55-76. 
No. 5. The religion of Handsome Lake: Its origin and development, by Merle H. Deardorff. Pp. 77-107.

No. 6. Local diversity in Iroquois music and dance, by Gertrude P. Kurath. Pp. 109-137.

No. 7. The Feast of the Dead, or Ghost Dance, at Six Nations Reserve, Canada, by William N. Fenton and Gertrude P. Kurath. Pp. 139-165.

No. 8. Iroquois women, then and now, by Martha Champion Randle. Pp. 167-180.

150. The modal personality structure of the Tuscarora Indians as revealed by the Rorschach test, by Anthony F. C. Wallace. viII +120 pp., 1 pl., 8 figs. 1952 .

151. Anthropological papers, numbers $33-42$. IX +507 pp., 37 pls., 25 figs., 7 maps. 1953. Out of print. Papers available in separate form.

No. 33. Of the Crow Nation, by Edwin Thompson Denig, edited with biographical sketch and footnotes by John C. Ewers. Pp. 1-74, pls. 1-6, map 1. Out of print.

No. 34. The water lily in Maya art: a complex of alleged Asiatic origin, by Robert L. Rands. Pp. 75-153, figs. 1-6. Out of print.

No. 35. The medicine bundles of the Florida Seminole and the Green Corn Dance, by Louis Capron. Pp. 155-210, pls. 7-15, figs. 7-10. Out of print.

No. 36. Technique in the music of the American Indian, by Frances Densmore. Pp. 213-216. Out of print.

No. 37. The belief of the Indian in a connection between song and the supernatural, by Frances Densmore. Pp. 217-223. Out of print.

No. 38. Aboriginal fish poisons, by Robert F. Heizer. Pp. 225-283, pls. 16-19, maps 2-4.

No. 39. Aboriginal navigation off the coasts of Upper and Baja California, by Robert F. Heizer and William C. Massey. Pp. 285-311, pls. 20-23, figs. 11 and 12 , maps 5-7.

No. 40. Exploration of an Adena Mound at Natrium, West Virginia, by Ralph S. Solecki. Pp. 313-395, pls. 24-29, figs. 13-19. Out of print.

No. 41. The Wind River Shoshone Sun Dance, by D. B. Shimkin. Pp. 397-484, pls. 30-37, figs. 20-25. Out of print.

No. 42. Current trends in the Wind River Shoshone Sun Dance, by Fred W. Voget. Pp. 485-499. Out of print.

152 Index to Schoolcraft's "Indian tribes of the United States," compiled by Frances S. Nichols. vr+257 pp. 1954.

153. La Venta, Tabasco: A study of Olmec ceramics and art, by Philip Drucker. With a chapter on structural investigations in 1943, by Waldo $\mathrm{R}$. Wedel, and appendix on technological analyses, by Anna O. Shepard. $\mathrm{x}+257$ pp., 66 pls., 64 figs. 1952. Out of print. 
154. River Basin Surveys Papers, Nos. 1-6. $\quad x v+336$ pp., 56 pls., 40 figs. 1953. Out of print. Papers available in separate form.

No. 1. Prehistory and the Missouri Valley development program: summary report on the Missouri River Basin archeological survey in 1948, by Waldo R. Wedel. Pp. xv-xvirI, 1-59, pls. 1-12, fig. 1. Out of print.

No. 2. Prehistory and the Missouri Valley development program: summary report on the Missouri River Basin archeological survey in 1949 , by Waldo R. Wedel. Pp. 61-101, pls. 1315. Out of print.

No. 3. The Woodruff ossuary, a prehistoric burial site in Phillips County, Kansas, by Marvin F. Kivett. Pp. 103-141, pls. 16-28, figs. 2-3.

No. 4. The Addicks dam site:

I. An archeological survey of the Addicks Dam Basin, southeast Texas, by Joe Ben Wheat. Pp. 143-252, pls. 29-47, figs. 4-23. Out of print.

II. Indian skeletal remains from the Doering and Kobs sites, Addicks Reservoir, Texas, by Marshall T. Newman. Pp. 253-266, figs. 24-28. Out of print.

No. 5. The Hodges site:

I. Two rock shelters near Tucumcari, New Mexico, by Herbert W. Dick. Pp. 267-284, pls. 48-54, figs. 2930. Out of print.

II. Geology of the Hodges site, Quay County, New Mexico, by Sheldon Judson. Pp. 285-302, figs. 31-35. Out of print.

No. 6. The Rembert mounds, Elbert County, Georgia, by Joseph R.

Caldwell. Pp. 303-320, pls. 55-56, figs. 36-40.

155. Prehistoric settlement patterns in the Virú Valley, Peru, by Gordon R. Willey. XxiI +453 pp., 60 pls., 88 figs. 1953. 156. The Iroquois Eagle Dance, an offshoot of the Calumet Dance, by William N. Fenton, with an analysis of the Iroquois Eagle Dance and songs, by Gertrude Prokosch Kurath. vi +324 pp., 28 pls., 36 figs. 1953. Out of print.

157. Anthropological Papers, numbers 43-48. III +415 pp., 76 pls., 23 figs. 1955. Out of print.

No. 43. Stone monuments of the Río Chiquito, Veracruz, Mexico, by Matthew W. Stirling. Pp. 1-23, pls. 1-26, fig. 1. Out of print.

No. 44. The Cerro de las Mesas offering of jade and other materials, by Philip Drucker. Pp. 25-68, pls. 27-54, figs. 2-9. Out of print.

No. 45. Archeological materials from the vicinity of Mobridge, South Dakota, by Waldo R. Wedel. Pp. 69-188, pls. 55-71, figs. 10-12. Out of print.

No. 46. The original Strachey vocabulary of the Virginia Indian language, by John P. Harrington. Pp. 189-202, 16 sheets of vocabulary with 16 keys. Out of print.

No. 47. The Sun Dance of the Northern Ute, by J. A. Jones. Pp. 203263, fig. 13. Out of prin'. 
No. 48. Some manifestations of water in Mesoamerican art, by Robert L. Rands. Pp. 265-393, pls. 72-76, figs. 14-23. Out of print.

158. River Basin Surveys Papers, No. 7: Archeological investigations in the Oahe Dam area, South Dakota, 1950-51, by Donald J. Lehmer. With appendixes by Theodore E. White, and Norton H. Nickerson and Ding Hou. $\mathrm{xI}+190$ pp., 22 pls., 56 figs., 6 maps. 1954. Out of print.

159. The horse in Blackfoot Indian culture, with comparative material from other western tribes, by John C. Ewers. xv+374 pp., 17 pls., 33 figs. 1955.

160. A ceramic study of Virginia archeology, by Clifford Evans. With appendix, An analysis of projectile points and large blades, by C. G. Holland. viII+195 pp., 30 pls., 23 figs. 1955. Out of print.

161. Seminole music, by Frances Densmore. xxviII+224 pp., 18 pls., 1 fig., 243 music scores. 1956.

162. Guaymí grammar and dictionary, with some ethnological notes, by Ephraim S. Alphonse. Ix+128 pp. 1956.

163. The Diné: Origin myths of the Navaho Indians, by Aileen O'Bryan. viI+194 pp. 1956. Out of print.

164. Anthropological papers, numbers $49-56$. $\mathrm{x}+355$ pp., 75 pls., 20 figs. 1957.

No. 49. The Ormond Beach Mound, East Central Florida, by Jesse D. Jennings, Gordon R. Willey, and Marshall T. Newman. Pp. $\mathrm{v}-\mathrm{x}+1-28$, pls. 1-12, figs. 1-4. Out of print.

No. 50. Hair pipes in Plains Indian adornment, a study in Indian and White ingenuity, by John C. Ewers. Pp. 29-85, pls. 13-37, maps 1-6. Out of print.

No. 51. Observations on some nineteenth-century pottery vessels from the Upper Missouri, by Waldo R. Wedel. Pp. 87-114, pls. 38-45, map 7.

No. 52. Revaluation of the Eastern Siouan problem, with particular emphasis on the Virginia branches-the Occaneechi, the Saponi, and the Tutelo, by Carl F. Miller. Pp. 115-212, maps 8-14.

No. 53. An archeological reconnaissance in Southeastern Mexico, by Matthew W. Stirling. Pp. 213-240, pls. 46-73, fig. 5, map 15. Out of print.

No. 54. Valladolid Maya enumeration, by John P. Harrington. Pp. 241-278.

No. 55. Letters to Jack Wilson, the Paiute Prophet, written between 1908 and 1911, edited and with an introduction by Grace M. Dangberg. Pp. 279-296.

No. 56. Factionalism at Taos Pueblo, New Mexico, by William N. Fenton. Pp. 297-344, pls. 74-75. 
165. Music of Acoma, Isleta, Cochiti, and Zuñi Pueblos, by Frances Densmore. xiIt-117 pp., 6 pls., 82 music transcriptions. 1957.

166. River Basin Surveys Papers, No. 8: Excavations in the MeNary Reservoir Basin near Umatilla, Oregon, by Douglas Osborne. With appendixes by Marshall T. Newman, Arthur Woodward, W. J. Kroll, and B. H. McLeod. Ix +258 pp., 40 pls., 6 figs., 19 maps. Out of print.

167. Archeological investigations at the mouth of the Amazon, by Betty J. Meggers and Clifford Evans. xxvin+664 pp., 112 pls., 206 figs., 71 tables. 1957. Out of print.

168. The Native Brotherhoods: Modern intertribal organizations on

the Northwest Coast, by Philip Drucker. Iv +194 pp. 1958.

169. River Basin Surveys Papers, numbers 9-14. IX +392 pp., 73 pls., 13 figs., 9 maps. 1958. Papers available in separate form.

No. 9. Archeological investigations in the Heart Butte Reservoir area, North Dakota, by Paul L. Cooper. Pp. 1-40, pls. $1-12$, figs. 1 and 2 , maps 1 and 2 .

No. 10. Archeological investigations at the Tuttle Creek Dam, Kansas, by Robert B. Cumming, Jr. Pp. 41-78, pls. 13-24, maps 3 and 4 .

No. 11. The Spain site (39LM301), a winter village in Fort Randall Reservoir, South Dakota, by Carlyle S. Smith and Roger T. Grange, Jr. Pp. 79-128, pls. 25-36, figs. 3 and 4, maps 5 and 6.

No. 12. The Wilbanks site $(9 \mathrm{CK}-5)$, Georgia, by William H. Sears. Pp. 129-194, pls. 37-45, figs. 5-9, map 7.

No. 13. Historic sites in and around the Jim Woodruff Reservoir area, Florida-Georgia, by Mark F. Boyd. Pp. 195-314, pls. 4655, figs. 10 and 11 , map 8.

No. 14. Six sites near the Chattahoochee River in the Jim Woodruff Reservoir area, Florida, by Ripley P. Bullen. Pp. 315357 , pls. 56-73, figs. 12 and 13 , map 9.

170. Excavations at La Venta, Tabasco, 1955, by Philip Drucker, Robert F. Heizer, and Robert J. Squier. With appendixes by Jonas E. Gullberg, Garniss H. Curtis, and A. Starker Leopold. vIII +312 pp., 63 pls., 82 figs. 1959.

171. The North Alaskan Eskimo: $\mathrm{A}$ study in ecology and society, by Robert F. Spencer. vi +490 pp., 9 pls., 2 figs., 4 maps. 1959. Out of print.

172. The story of a Tlingit community: $\Lambda$ problem in the relationship between archeological, ethnological, and historical methods, by Frederica de Laguna. $x+254$ pp., 11 pls., 18 figs., 1960 . Out of print. 
173. Anthropological Papers, numbers 57-62. III +498 pp., 61 pls., 37 figs., 2 maps. 1960. Papers available in separate form.

No. 57. Preceramic and ceramic cultural patterns in northwest Virginia, by C. G. Holland. Pp. 1-129, figs. 1-12.

No. 58. An introduction to Plains Apache archeology-the Dismal River Aspect, by James H. Gunnerson. Pp. 131-260, pls. 1-38, figs. 13-24.

No. 59. The use of the atlatl on Lake Patzcuaro, Michoacan, by M. W. Stirling. Pp. 261-268, pls. 39-41.

No. 60. A Caroline Islands seript, by Saul H. Riesenberg and Shigeru Kaneshiro. Pp. 269-333, pls. 42-44, figs. 25-28, map 1.

No. 61. Dakota winter counts as a source of Plains history, by James H. Howard. Pp. 335-416, pls. 45-47.

No. 62. Stone tipi rings in north-central Montana and the adjacent portion of Alberta, Canada: Their historical, ethnological, and archeological aspects, by Thomas F. Kehoe. Pp. 417473 , pls. 48-61, figs. 29-37, map 2.

174. An introduction to Kansas archeology, by Waldo $R$. Wedel. With description of the skeletal remains from Doniphan and Scott Counties, Kansas, by T. D. Stewart. $\quad$ xvir +723 pp., 97 pls., 109 figs. 1959. Out of print.

175. Mohave ethnopsychiatry and suicide: The psychiatric knowledge and the psychic disturbances of an Indian tribe, by George Devereux. vi +586 pp., 10 pls. 1961.

176. River Basin Surveys Papers, numbers 15-20: Ix +337 pp., 65 pls., 25 figs., 7 maps. 1960. Papers available in separate form.

No. 15. Historic sites archeology on the Upper Missouri, by Merrill J. Mattes. Pp. 1-23.

No. 16. Historic sites archeology in the Fort Randall Reservoir, South Dakota, by John E. Mills. Pp. 25-48, pls. 1-9, figs. 1-2, map 1 .

No. 17. The excavation and investigation of Fort Lookout Trading Post II (39LM57) in the Fort Randall Reservoir, South Dakota, by Carl F. Miller. Pp. 49-82, pls. 10-18, figs. 3-14, map 2.

No. 18. Fort Pierre II (39ST217), a historic trading post in the Oahe Dam area, South Dakota, by G. Hubert Smith. Pp. 83-158, pls. 19-30, maps 3 and 4.

No. 19. Archeological investigations at the site of Fort Stevenson (32ML1), Garrison Reservoir, North Dakota, by G. Hubert Smith. With appendix by Carlyle S. Smith. Pp. 159-238, pls. 31-54, figs. 15-20, maps 5 and 6.

No. 20. The archeology of a small trading post (Kipp's Post, 32MN1) in the Garrison Reservoir, North Dakota, by Alan R. Woolworth and W. Raymond Wood. Pp. 239-305, pls. 55-65, figs. 21-25, map 7. 
No. 177. Archeological investigations in British Guiana, South America, by Clifford Evans and Betty J. Meggers. xxi+ 418 pp., 68 pls., 127 figs. 1960.

No. 178. Index to Bulletins 1-100 of the Bureau of American Ethnology, by Biren Bonnerjea. In press.

No. 179. River Basin Surveys Papers, numbers 21-24. $x x+337$ pp., 56 pls., 43 figs., 7 maps. 1961. Papers available in separate form.

No. 21. Excavations at Texarkana Reservoir, Sulphur River, Texas, by Edward B. Jelks. Pp. xim-xvint-1-78, pls. 1-17, figs. 1-9.

No. 22. Archeological investigations at the Coralville Reservoir, Iowa. by Warren W. Caldwell. Pp. 79-148, pls. 18-29, figs. 10-20.

No. 23. The McNary Reservoir: A study in Plateau archeology, by Joel L. Shiner. Pp. 149-266, pls. 30-46, figs. 25-40, maps 1-7.

No. 24. The Sheep Island site and the Mid-Columbia Valley, by Douglas Osborne, Alan Bryan, and Robert H. Crabtree. Pp. 267-306, pls. 45-56, figs. 41-43.

No. 180. Symposium on Cherokee and Iroquois culture, edited by William N. Fenton and John Gulick. Papers 1-25. vi+292 pp. 1961.

No. 1. Foreword by the editors.

No. 2. Iroquois-Cherokee linguistic relations, by Floyd G. Lounsbury.

No. 3. Comment on Floyd G. Lounsbury's "Iroquois-Cherokee Linguistic Relations," by Mary R. Haas.

No. 4. Iroquois archeology and settlement patterns, by William A. Ritchie.

No. 5. First comment on William A. Ritchie's "Iroquois Archeology and Settlement Patterns," by William H. Sears.

No. 6. Second comment on William A. Ritchie's "Iroquois Archeology and Settlement Patterns," by Douglas S. Byers.

No. 7. Cherokee archeology, by Joffre L. Coe.

No. 8. Comment on Joffre L. Coe's "Cherokee Archeology," by Charles H. Fairbanks.

No. 9. Eastern Woodlands community typology and acculturation, by John Witthoft.

No. 10. Comment on John Witthoft's "Eastern Woodlands Community Typology and Acculturation," by John M. Goggin.

No. 11. Cherokee economic cooperatives: the Gadugi, by Raymond D. Fogelson and Paul Kutsche.

No. 12. The rise of the Cherokee State as an instance in a class: The "Mesopotamian" career to statehood, by Fred O. Gearing.

No. 13. Comment on Fred O. Gearing's "The Rise of the Cherokee State as an Instance in a Class: The 'Mesopotamian' Career to Statehood," by Annemarie Shimony.

No. 14. Cultural composition of the Handsome Lake Religion, by Anthony F. C. Wallace. 
No. 15. Comment on Anthony F. C. Wallace's "Cultural Composition of the Handsome Lake Religion," by Wallace L. Chafe.

No. 16. The Redbird Smith movement, by Robert K. Thomas.

No. 17. Comment on Robert K. Thomas's "The Redbird Smith Movement," by Fred W. Voget.

No. 18. Effects of environment on Cherokee-Iroquois ceremonialism, music, and dance, by Gertrude P. Kurath.

No. 19. Comment on Gertrude P. Kurath's "Effects of Environment on Cherokee-Iroquois Ceremonialism, Music, and Dance," by William C. Sturtevant.

No. 20. The Iroquois fortunetellers and their conservative influence, by Annemarie Shimony.

No. 21. Change, persistence, and accommodation in Cherokee medicomagical beliefs, by Raymond D. Fogelson.

No. 22. Some observations on the persistence of aboriginal Cherokee personality traits, by Charles $\mathrm{H}$. Holzinger.

No. 23. First Comment on Charles H. Holzinger's "Some Observations on the Persistence of Aboriginal Cherokee Personality Traits," by David Landy.

No. 24. Second Comment on Charles H. Holzinger's "Some Observations on the Persistence of Aboriginal Cherokee Personality Traits," by John Gulick.

No. 25. Iroquoian culture history: A general evaluation, by William N. Fenton.

No. 181. Isleta paintings, with introduction and commentary by Elsie Clews Parsons, edited by Esther S. Goldfrank. In press. No. 182. Archeology of the John H. Kerr Reservoir Basin, Roanoke River, Virginia-North Carolina, by Carl F. Miller. With appendix by Lucile E. Hoyme and William M. Bass. In press.

No. 183. Seneca Thanksgiving rituals, by Wallace L. Chafe. III +301 pp. 1961.

No. 184. The Pucblo of Sia, New Mexico, by Leslie A. White. In press. No. 185. River Basin Surveys Papers, numbers 26-32. In press.

No. 26. Small sites in and about Fort Berthold Indian Reservation, Garrison Reservoir, by George Metcalf.

No. 27. Star Village: A fortified historic Arikara site in Mercer County, North Dakota, by George Metcalf.

No. 28. The dance hall of the Santee Bottoms on the Fort Berthold Reservation, Garrison Reservoir, North Dakota, by Donald D. Hartle.

No. 29. Crow-Flies-High (32MZ1), a historic Hidatsa village in the Garrison Reservoir Area, North Dakota, by Carling Malouf.

No. 30. The Stutsman Focus: An aboriginal culture complex in the Jamestown Reservoir Area, by R. P. Wheeler.

No. 31. Archeological manifestations in the Toole County section of the Tiber Reservoir Basin, Montana, by Carl F. Miller.

No. 32. Archeological salvage investigations in the Lovewell Reservoir area, Kansas, by Robert W, Neuman. 
No. 186. Anthropological Papers, numbers 63-67. In press.

No. 63. Tarqui, an early site in Manabi Province, Ecuador, by Matthew W. and Marion Stirling.

No. 64. Blackfoot Indian pipes and pipe making, by John C. Ewers.

No. 65. The Warihio Indians of Sonora-Chihuahua: An ethoographic survey, by Howard Scott Gentry.

No. 66. The Yaqui Deer Dance: A study in cultural change, by Carleton Stafford Wilder.

No. 67. Chippewa !mat-weaving techniques, by Karen Daniels Petersen. 


\section{PUBLICATIONS OF THE INSTITUTE OF SOCIAL ANTHROPOLOGY}

1. Houses and house use of the Sierra Tarascans, by Ralph L. Beals, Pedro Carrasco, and Thomas McCorkle. $x+37$ pp., 8 pls., 20 figs. 1944. Out of print.

2. Cherán: A Sierra Tarascan village, by Ralph $\mathrm{L}$. Beals. $x+225$ pp., 8 pls., 19 figs., 5 maps. 1946. Out of print.

3. Moche: A Peruvian coastal community, by John Gillin. viI +166 pp., 26 pls., 8 figs., 1 map. 1947. Out of print.

4. Cultural and historical geography of southwest Guatemala, by Felix Webster McBryde. $x v+184$ pp., 47 pls., 2 figs., 25 maps. 1947. Out of print.

5. Highland communities of central Peru, by Harry Tschopik, Jr. viII+56 pp., 16 pls., 2 maps. 1947. Out of print.

6. Empire's children: The people of Tzintzuntzan, by George M. Foster assisted by Gabriel Ospina. v+297 pp., 16 pls., 36 figs., 2 maps. 1948. Out of print.

7. Cultural geography of the modern Tarascan area, by Robert C.

West. vi +77 pp., 14 pls., 6 figs., 21 maps. 1948. Out of print.

8. Sierra Popoluca speech, by Mary I. Foster and George M. Foster. III +45 pp. 1948.

9. The Terena and Caduveo of southern Mato Grosso, Brazil, by Kalervo Oberg. IV +72 pp., 24 pls., 2 charts, 4 maps. 1949.

10. Nomads of the long bow: The Siriono of eastern Bolivia, by Allan R. Holmberg. IV +104 pp., 7 pls., 4 charts, 1 map. 1950. Out of print.

11. Quiroga: A Mexican municipio, by Donald D. Brand. v+242 pp., 35 pls., 4 maps. 1951. Out of print.

12. Cruz das Almas: $A$ Brazilian village, by Donald Pierson. $x+226$ pp., 20 pls., 13 figs., 2 maps. 1951. Out of print.

13. The Tajín Totonac. Part 1: History, subsistence, shelter, and technology, by Isabel Kelly and Angel Palerm. xIv+369 pp., 33 pls., 69 figs., 18 maps. 1952. Out of print.

14. The Indian caste of Peru, 1795-1940: A population study based upon tax records and census reports, by George Kubler. vi+71 pp., 2 pls., 1 fig., 20 maps. 1952.

15. Indian tribes of northern Mato Grosso, Brazil, by Kalervo Oberg. With an appendix entitled "Anthropometry of the Umotina, Nambicuara, and Iranxe, with comparative data from other northern Mato Grosso tribes," by Marshall T. Newman. viII +144 pp., 10 pls., 2 figs., 14 charts, 3 maps. 1953.

16. Penny capitalism, a Guatemalan Indian economy, by Sol Tax. $\mathrm{x}+230$ pp., 6 maps, 19 charts. 1953. Out of print. $615214-62-4$ 


\section{CONTRIBUTIONS TO NORTH AMERICAN ETHNOLOGY}

(All the volumes of this group except vol. 6 are out of print)

Contributions to North American ethnology, by J. W. Powell, Geologist in Charge, Geographical and Geological Survey of the Rocky Mountain Region, U.S. Department of the Interior. $4^{\circ}$. Vols. 1-3.

Contributions to North American ethnology, by J. W. Powell, Director, Bureau of Ethnology, Smithsonian Institution. $4^{\circ}$. Vols. $4-7,9$.

\section{Volume 1, 1877:}

Part I. Tribes of the extreme Northwest, by W. H. Dall. Pp. 1-156, illus.

On the distribution and nomenclature of the native tribes of Alaska and the adjacent territory.

On succession in the shell-heaps of the Aleutian Islands.

On the origin of the Innuit.

Appendix to part I. Linguistics.

Notes on the natives of Alaska (communicated to the late George Gibbs, M.D., in 1862), by His Excellency J. Furuhelm, late Governor of the Russian-American colonies.

Terms of relationship used by the Innuit: a series obtained from natives of Cumberland inlet, by W. H. Dall.

Vocabularies [by George Gibbs and W. H. Dall].

Note on the use of numerals among the T'sim si-an', by George Gibbs, M.D.

Part Ir. Tribes of western Washington and northwestern Oregon, by

George Gibbs, M.D. Pp. 157 361, pocket map.

Appendix to part II. Linguistics.

Vocabularies [by George Gibbs, Wm. F. Tolmie, and G. Mengarini].

Dictionary of the Niskwalli [Niskwalli-English and EnglishNiskwalli], by George Gibbs.

VoLUME 2, 1890 [1891]:

The Klamath Indians of southwestern Oregon, by Albert Samuel Gatschet. 2 vols.

VOLUME 3, 1877:

Tribes of California, by Stephen Powers. 635 pp., frontispiece, 44 figs.

(incl. 42 pls.), 3 pp. music, pocket map.

Appendix. Linguistics, edited by J. W. Powell. Pp. 439-613.

VOLUME 4, 1881:

Houses and house-life of the American aborigines, by Lewis H. Morgan. $\mathrm{xIV}+281 \mathrm{pp}$, frontispiece, 56 figs. (incl. $28 \mathrm{pls}$.).

VolUME 5, 1882:

Observations on cup-shaped and other lapidarian seulptures in the Old

World and in America, by Charles Rau, 112 pp., 61 figs. (forming 35 pls.). 1881, 
On prehistoric trephining and cranial amulets, by Robert Fletcher, M. R. C. S. Eng., act. asst. surgeon, U.S. Army. 32 pp., 9 pls., 2 figs. 1882.

A study of the manuscript Troano, by Cyrus Thomas, Ph.D., with an introduction by D. G. Brinton, M.D. [The graphic system and ancient method of the Mayas.] xxxviI +237 pp., 9 pls., 101 figs., 25 small unnumbered cuts. 1882.

Volume 6, 1890 [1892]:

The Cegiha language, by James Owen Dorsey. xvm +794 pp. Volume 7, 1890 [1892]:

A Dakota-English dictionary, by Stephen Return Riggs, edited by James Owen Dorsey. $\mathrm{x}+665 \mathrm{pp}$.

Volume 8: Not published.

Volume 9, 1893 [1894]:

Dakota grammar, texts, and ethnography, by Stephen Return Riggs, edited by James Owen Dorsey. xxxir +239 pp.

\section{INTRODUCTIONS ${ }^{1}$}

(In quarto size)

\section{(All volumes of this group are out of print)}

(1) Introduction to the study of Indian languages, with words, phrases, and sentences to be collected, by J. W. Powell. [Seal of the Department of the Interior.] 104 pp., 10 blank leaves. 1877.

Second edition as follows:

(2) Introduction to the study of Indian languages, with words, phrases, and sentences to be collected, by J. W. Powell. Second edition. $\mathrm{xI}+228$ pp., 10 blank leaves, 4 kinship charts in pocket. A $16^{\circ}$ "Alphabet" of 2 leaves accompanies the work. 1880.

(3) Introduction to the study of sign language among the North American Indians as illustrating the gesture speech of mankind, by Garrick Mallery, brevet lieut. col., U.S. Army. Iv +72 pp., 33 unnumbered figs. 1880 .

(4) Introduction to the study of mortuary customs among the North American Indians, by Dr. H. C. Yarrow, act. asst. surg., U.S. Army. IX +114 pp. 1880.

\footnotetext{
1 The numbers in parentheses are given for convenience in reference.
} 


\section{MISCELLANEOUS PUBLICATIONS 2}

(All the publications in this group except No. 10 are out of print)

(1) $\Lambda$ collection of gesture-signs and signals of the North American Indians with some comparisons, by Garrick Mallery, brevet lieut. col. and formerly acting chief sigual officer, U.S. Army. $4^{\circ} .329 \mathrm{pp}$. 1880 .

Note, -250 copies printed for use of collaborators only.

(2) Proof-sheets of a bibliography of the languages of the North American Indians, by James Constantine Pilling. (Distributed only to collaborators.) $4^{\circ} . \mathrm{xu}+1135 \mathrm{pp}, 29 \mathrm{pls}$. (facsimiles). 1885.

Note.-Only 110 copies printed for the use of collaborators, 10 of them on one side of the sheet. It was the intention to have this Bibliography form volume 10 of the Contributions to North American Ethnology, but the work assumed such proportions that it was subsequently deemed advisable to publish it as a part of the series of Bulletins, devoting a Bulletin to each linguistic stock.

(3) Linguistic families of the Indian tribes north of Mexico, with provisional list of the principal tribal names and synonyms. $16^{\circ}$. $55 \mathrm{pp} .[1885$.

Note.-A few copies printed for the use of the compilers of a Dictionary of American Indiaus [Handbook. See Bulletin 30]. It is without title page, name, or date, but was compiled from a manuscript list of Indian tribes by James Mooney.

(4) [Map of] Linguistic stocks of American Indians north of Mexico, by J. W. Powell. [1891.]

Note.-A limited edition of this map, which forms plate 1 of the Seventh Annual Report, was issued on heavy paper, 19 by 22 inches, for the use of students. This map was revised and published in the Report on Indians Taxed and Not Taxed in the United States at the Eleventh Census, 1890. (See Note 7.)

(5) Tribes of North America, with synonymy. Skittagetan family. $4^{\circ} .13$ pp. [1890.]

Note.-A few eopies printed for the use of the compilers of the Handbook of American Indians. It was prepared by H. W. Henshaw, and contains two samples of style for the Handbook, the second beginning on page 7 with the head, "Dictionary of Indian tribal names." (See Bulletin 30.)

(6) [Advance pages] Dictionary of American Indians north of Mexico... $8^{\circ} .33$ pp. 1903.

Note.-Prepared by F. W. Hodge. Two hundred and fifty copies printed by the Smithsonian Institution for the use of the compilers of the Dictionary [Handbook. See Bulletin 30].

- 'The numbers in parentheses are given for convenience in reference. 
(7) [Map of] Linguistic stocks of American Indians north of Mexico, by J. W. Powell. [1906.]

Note.-Printed on heavy paper in advance of the Handbook of American Indians (Bulletin 30), part 1, of which it forms an illustration.

(8) Article on Bureau of American Ethnology (with list of publications). [By W. H. Holmes.] Reprinted from Handbook of American Indians, Bulletin 30 (pt. 1), pp. 171-176, Bureau of American Ethnology. $8^{\circ} .5 \mathrm{pp}$. [1906.]

(9) Indian missions north of Mexico, by James Mooney. Reprinted from Handbook of American Indians, Bulletin 30 (pt. 1), Bureau of American Ethnology. Washington. $8^{\circ}$. 39 pp. 1907.

(10) Circular of information regarding Indian popular names. $8^{\circ}$. 8 pp. [1915.] (Revised edition October 1926.)

(11) [Map of] Linguistic families of American Indians north of Mexico, by J. IV. Powell. Revised by members of the staff of the Bureau of American Ethnology. 1915. (Revised edition 1926.)

(12) List of publications of the Bureau of American Ethnology, with index to authors and titles. Revised to June 30, 1944. $68 \mathrm{pp}$. 1944.

(13) List of publications of the Bureau of American Ethnology, with index to authors and titles. Revised to June 30, 1949. $101 \mathrm{pp}$. 1949.

(14) List of publications of the Bureau of American Ethnology, with index to authors and titles. Revised to June 30, 1956. $112 \mathrm{pp}$. 1956. 


\section{INDEX TO AUTHORS AND TITLES ${ }^{3}$}

$A=$ Annual Report. $B=$ Bulletin. $C=$ Contributions to North American Ethnology. I=Introductions. $M \Rightarrow$ Miscellaneous Publications. $\mathrm{P}=$ Publications of the Institute of Social Anthropology.

Aboriginal culture of the Southeast (Swanton)

Aboriginal fish poisons (Heizer)

Aboriginal house mounds (Fowke)

Aboriginal navigation off the coasts of Upper and Baja

California (Heizer and Massey).

Aboriginal sociopolitical groups, Basin-plateau (Stew- B ard).

Aborigines of Porto Rico and neighboring islands A (Fewkes).

Achagua and their neighbors, The (Hernández de B Alba).

Ackerknecht, Erwin H. Medical practices.

Acoma, New material from (White)

Acoma and other records, Origin myth of (Stirling) -..

Acoma Indians, The (White).

Aconite poison whaling in Asia and America (Heizer) --

Activital similarities (Powell)

Activities. See Esthetology; Philology; Sociology;

Sophiology; Technology.

Addicks dam site, The:

I. An archeological survey of the Addicks Dam Basin, southeast Texas (Wheat).

II. Indian skeletal remains from the Doering and Kobs sites, Addicks Reservoir, Texas (Newman).

Additional studies of the arts, crafts, and customs of the

Guiana Indians, with special reference to those of southern British Guiana (Roth).

Alabama:

Archeological survey of Pickwick Basin in (Webb B and DeJarnette).

northern, An archeological survey of Wheeler Basin B in (Webb).

Pickwick Basin, geology of (Jones) _....._._..... I

Pickwick Basin, skeletal material from (Newman B and Snow).

Alacaluf, The (Bird)

42,673 .

151, Anthrop. Pap.

No. 38.

76,161 .

151, Anthrop. Pap. No. 39 .

120.

25,3 .

143, vol. 4, pp. 399412.

143, vol. 5 .

136, Anthrop. Pap. No. 32.

135.

$47,17$.

133, Anthrop. Pap. No. 24.

3, LXV.

B 154, Riv. Bas. Surv. Pap. No. 4, Pt. 1. 154, Riv. Bas. Surv. Pap. No. 4, Pt. 2.

B 91.

\section{9.}

122.

$129,327$.

$129,393$.

143, vol. 1, pp. 5579.

Alaska:

Anthropological survey in (Hrdlička)

A 46,19 .

Notes on the natives of (Furuhelm)

${ }^{8}$ Do not make selections from this index, but from the list. The index does not show the numbers "out of print." 
Algonquian, Siouan, and Caddoan tribes west of the $B$ Mississippi, Burials of the (Bushnell).

Algonquian, Siouan, and Caddoan tribes west of the B Mississippi, Villages of the (Bushnell).

Algonquian languages, Bibliography of the (Pilling) -..Algonquian tribes, Preliminary report on the linguistic classification of (Michelson).

See also Bulletin 40 (pt. 1).

Algonquin, River Desert, Art processes in birchbark of the (Speck).

Alphonse, Ephraim S. Guaymí grammar and dictionary, with some ethnological notes.

Alsea texts and myths (Frachtenberg).

Amanayé, The (Nimuendajú and Métraux)

Amaní, The Patángoro and (Kirchhoff)

Amazon, Little-known tribes of the lower (Nimuendajú).

Amazon Basin, The archeology of the (Meggers)

Amazon River, Tribes of the middle and upper (Metraux).

Amulets, cranial, Prehistoric trephining and ( $R$. C Fletcher).

Analytical and critical bibliography of the tribes of Tierra del Fuego and adjacent territory (Cooper).

Andean area Indians, anthropometric relations with Quichua-speaking Indians of Province of Imbabura (Ecuador).

Andean calendar, The (Valcárcel)

Andean culture, The northeastern extension (Métraux and Kirchhoff).

Andean Highlands, The: An introduction (Bennett)...

Andean peoples, The social and political organization of the (Kirchhoff).

Animal carvings from mounds of the Mississippi Valley (Henshaw).

Animism and folk-lore of the Guiana Indians (Roth) Anthropological needs and possibilities in Central America (Strong and Johnson).

Anthropological papers:

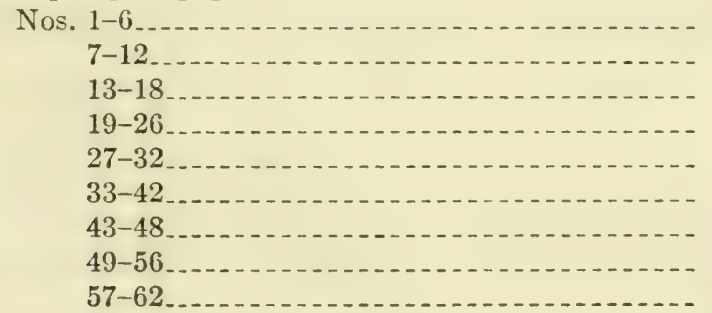

83.

77.

13.

$28,221$.

128, Anthrop. Pap. No. 17.

162.

67.

143, vol. 3, pp. 199202.

143, vol. 4, pp. 339348.

143, vol. 3, pp. 209 211.

B 143, vol. 3, pp. 149166.

143, vol, 3, pp. 687712.

5.

63.

128, Anthrop. Pap. No. 16.

B 143, vol. 2 , pp. $471-$ 476.

143, vol. 4, pp. 349369.

143, vol. 2, pp. 160 .

143, vol. 5, pp. 293311.

$2,117$.

30, 103.

143, vol. 4, pp. 293296.

119.

123.

128.

133.

136.

151.

157.

164.

173. 
Anthropological survey in Alaska (Hrdlička)

Anthropologic data, Limitations to the use of some (Powell).

Anthropometry of South American Indians (Steggerda).

Anthropometry of South American Indian skeletal remains (Stewart and Newman).

Anthropometry of the Indians of Brazil, The (Bastos d'Avila).

Anthropometry of the Indians of Chile, The (Henckel) -

Antiquities:

Certain, of eastern Mexico (Fewkes) ..........

Handbook of American (Holmes)

Mexican and Central American, calendar systems, history and (Seler and others).

of central and southeastern Missouri (Fowke)..... of region between Mancos and La Plata Rivers in southwestern Colorado (Morris).

of the Jemez Plateau, New Mexico (Hewett) _....of the Mesa Verde National Park Cliff Palace (Fewkes).

of the Mesa Verde National Park Spruce-tree House (Fewkes).

of the upper Gila and Salt River valleys in Arizona and New Mexico (Hough).

of the upper Verde and Walnut Creek valleys, Arizona (Fewkes).

Antiquity of man in South America, The (McCown).. Apache, The medicine-men of the (Bourke) ........... Aparicio, Francisco de:

The archeology of the Paraná River

The Comenchingón .

Apiacá, The Cayabi, Tapanyuna, and (Nimuendajú) --

Arapaho, northern, flat pipe and the ceremony of covering the pipe (Carter).

Arapaho child life and its cultural background (Hilger) -

Arapium, The Maué and (Nimuendajú) ............

Araucanians, The (Cooper)

Araucanians in Argentina, The expansion of the (Canals Frau).

Arauquin, Archeology of (Petrullo)

Arawak, The (Rouse)

Archeological expedition to Arizona in 1895 (Fewkes) - Archeological explorations at Macon, Ga., A preliminary report on (Kelly).
A $46,19$.

A 1,71 .

B 143, vol. 6, pp. 57-

69.

B 143 , vol. 6 , pp. 19 42.

143 , vol. 6, pp. $71-$ 84.

143 , vol. $6, \mathrm{pp} .121-$ 135.

25,221 .

60.

28.

37.

33,155 .

32.

51.

41.

35.

28,181 .

143, vol. 6, pp. 1-9.

A 9,443 .

143, vol. 3, pp. 5767.

B 143, vol. 2, pp. 673685.

143, vol. 3, pp. 307320.

119, Anthrop. Pap. No. 2.

148.

143 , vol. 3 , pp. 245 254.

B 143 , vol. 2, pp. $687-$ 760.

143, vol. 2, pp. 761766.

123, Anthrop. Pap. No. 12.

143, vol. 4, pp. 507546.

A 17,519 .

B 119, Anthrop. Pap. No. 1. 
Archeological explorations in northeastern Arizona B (Kidder and Guernsey).

Archeological investigations (Fowke)

Archeological investigations-II (Fowke)

Archeological investigations at Buena Vista Lake, California (Wedel).

Archeological investigations at the Coralville Reservoir, B Iowa (Caldwell).

Archeological investigations at the mouth of the Ama- B zon (Meggers and Evans).

Archeological investigations at the site of Fort Stevenson (32ML1), Garrison Reservoir, North Dakota, (G. Hubert Smith). With appendix by Carlyle S. Smith.

Archeological investigations at the Tuttle Creek Dam, Kansas (Cumming, Jr.).

Archeological investigations in British Guiana, South America (Evans and Meggers).

Archeological investigations in the Corozal District of British Honduras ( $T$. and M. Gann).

Archeological investigations in the Heart Butte Reservoir area, North Dakota (Cooper).

Archeological investigations in the Oahe Dam area, South Dakota, 1950-51 (Lehmer).

Archeological manifestations in the Toole County section of the Tiber Reservoir Basin, Montana. In press.

Archeological materials from the vicinity of Mobridge, South Dakota (Wedel).

Archeological observations north of the Rio Colorado (Judd).

Archeological reconnaissance of southern Utah (Steward).

Archeological reconnaissance of Tabasco and Campeche (Stirling).

Archeological remains in the Whitewater District, eastern Arizona. Part I: House types (Roberts).

Archeological remains in the Whitewater District, eastern Arizona. Part II: Artifacts and burials (Roberts).

Archeological salvage investigations in the Lovewell Reservoir area, Kansas. (Neuman). In press.

Archeological survey of Pickwick Basin in the adjacent portions of the States of Alabama, Mississippi, and Tennessee (Webb and DeJarnette).

Archeological survey of the Addicks Dam Basin, southeast Texas (TWheat).

Archeological survey of the Norris Basin in eastern Tennessee, An (Webb).

Archeological survey of Wheeler Basin on the Tennessee River in northern Alabama, An (Webb).

Archeological survey on the northern Northwest Coast (Drucker).

Archeological work in Hawaii (Fowke)

Archeologic investigations in James and Potomac Val- $P$ leys (Fowke).
65.

76.

44, 399 .

130.

179, Riv. Bas. Surv.

Pap. No. 22.

167.

176, pp. 159-238.

B 169.

B 177.

B

123, Anthrop. Pap.

No. 7.

B 169 .

B

158, Riv. Bas. Surv. Pap. No. 7.

B

185, Riv. Bas. Surv. Pap. No. 31.

B

157, Anthrop. Pap.

No. 45.

B

82.

B

128, Anthrop. Pap. No. 18.

B

164, Anthrop. Pap. No. 53.

121.

126.

B

185, Riv. Bas. Surv. Pap. No. 32.

B 129.

B 154, Riv. Bas. Surv.

B

118.

Pap. No. 4, Pt. 1.

B

122.

133, Anthrop. Pap.

No. 20.

76, 174 .

23. 
Archeology, Cuzco (Valcárcel)

Archeology, Pawnee, An introduction to (Wedel)

Archeology of Arauquin (Petrullo)

Archeology of a small trading post (Kipp's Post, 32MN1) in the Garrison Reservoir, North Dakota, The (Wood and Woolworth).

Archeology of Central America, The: An introduction B (Strong).

Archeology of Colombia, The (Bennett)

Archeology of Costa Rica and Nicaragua, The (Strong)_ B

Archeology of Ecuador, The (Collier)

Archeology of Honduras, The (Strong)

Archeology of Panamá, The ((Lothrop)

Archeology of Patagonia, The (Bird)

Archeology of San Augustín and Tierradentro, Colombia, The (Hernández de Alba).

Archeology of the Amazon Basin, The (Meggers) .....

Archeology of the Central Andes, The (Bennett) ....-

Archeology of the Greater Pampa, The (Willey)......

Archeology of the John H. Kerr Reservoir Basin, Roaoke River, Virginia-North Carolina'(Miller). In press. Archeology of the Paraná River, The (Aparicio).......

Archeology of the Popayán region, Colombia, The (Lehmann).

Archeology of Venezuela, The (Kidder)

Architecture, A study of Pueblo Tusayan and Cibola (V. Mindeleff).

Argentina, Cephalic deformations of the Indians in (Imbelloni).

Argentina, The Diaguita of (Márquez Miranda) .......

Argentina, The present status of the theories concerning primitive man in (Frenguelli).

Arizona:

Aboriginal remains in Verde Valley in (C. Mindeleff).

Antiquities of the upper Gila and Salt River Val- B leys (Hough).

Archeological explorations in northeastern (Kidder B and Guernsey).
143, vol. 2, pp. 177182.

112.

123, Anthrop. Pap. No. 12.

176, Riv. Bas. Surv. Pap. No. 20.

143, vol. 4, pp. 6970 .

143, vol. 2 , pp. $823-$ 850.

143, vol. 4, pp. $121-$ 142.

B 143, vol, 2, pp.767784 .

B 143 , vol. 4 , pp. 71120.

B 143 , vol. 4, pp. 143167.

B 143, vol. 1, pp. 1724.

143, vol. 2, pp. 851859.

B 143, vol. 3, pp. 149166.

B 143, vol. 2, pp. 61147.

B 143 , vol. 1, pp. 2546

B 182 .

B 143, vol. 3 , pp. 5767.

B 143, vol. 2, pp. 861864.

B 143, vol. 4, pp. 413438.

A 8,3 .

143, vol. 6, pp. 5355.

B 143, vol. 2, pp. 637654.

B 143, vol. 6, pp. 1117.

A $13,179$.

35.

65. 
Arizona-Continued

eastern, Archeological remains in the White water District. Part I: House types (Roberts).

eastern, Archeological remains in the Whitewater District. Part II: Artifacts and burials (Roberts).

eastern, Skeletal remains from the Whitewater District (Stewart).

eastern, The ruins at Kiatuthlanna (Roberts)....

Flagstaff, A survey of prehistoric sites in the region of (Colton).

Illustrated catalogue of collections from, in 1879 (J. Stevenson).

Illustrated catalogue of collections from, in 1881 (J. Stevenson).

Navaho National Monument, visit to (Fewkes).-.-

The cliff-ruins of Canyon de Chelly in (C. Mindeleff). See also Casa Grande; Tusayan.

Armstrong, John M., and Métraux, Alfred. The Goajiro.

Art:

Ancient, of the province of Chiriqui, Colombia (Holmes).

ceramic, Form and ornament in (Holmes) in shell, of the ancient Americans (Holmes) .......

South American (Kroeber)

Prehistoric textile, of eastern United States (Holmes).

processes in birchbark of the River Desert Algonquin, a circumboreal trait (Speck).

Stone (Fowke) tertile, A study of the (Holmes)

Artifacts and burials, Whitewater District, eastern Arizona (Roberts).

Artists, native, Hopi katcinas drawn by (Fewkes) .....-

Arts, crafts, and customs of the Guiana Indians, Additional studies of the (Roth).

Arts, crafts, and customs of the Guiana Indians, Introductory study of the (Roth).

Aruã, The Turiwara and (Nimuendajú)

Atacameño, The (Bennett)

Atakapa language, accompanied by text material, A B dictionary of the (Gatschet and Swanton).

See also Bulletin 68.

Athapascan languages, Bibliography of the (Pilling) _.- B

See also Bulletin 40 (pt. 1).

Atlatl, The use of the, on Lake Patzuaro, Michoacán B (Stirling).

Autobiography of a Fox Indian woman (Michelson)...-

Aymara, The (Tschopik)

B 121 .

B 126 .

B $126,153$.

B 100 .

B 104 .

A 2,307 .

A 3, 511 .

B 50.

A 16,73 .

B 143, vol. 4, pp. 369383.

A 6,3 .

A 4,437 .

A 2,179 .

B 143, vol. 5, pp. 411492.

A 13, 3 .

B 128, Anthrop. Pap. No. 17.

A 13,47 .

A $\quad 6,189$

B 126.

A 21, 3.

B 91.

A 38,25 .

B 143, vol. 3, pp. 193-

198.

B 143, vol. 2, pp. 599-

618.

108.

B 14.

B 173, Anthrop. Pap. No. 59.

A 40, 291.

B 143, vol. 2, pp. 501573. 
Baldus, Herbert. See Métranx, Alfred, and Baldus, Herbert.

Ball, Sydney H. The mining of gems and ornamental stones by American Indians.

Bark cloth (Métraux)

Basal metabolic rates of South American Indians, The (Wilson).

Basin-plateau aboriginal sociopolitical groups (Steward).

Basket Maker site in the Chaco Canyon, New Mexico, Shabik'eshchee village, a late (Roberts).

Basketry (O'Neale)

Basketry, Coiled, in British Columbia and surrounding region (Haeberlin, Teit, and Roberts).

Bass, William M., and Hoyme, Lucile E. Human skeletal material from site $44 \mathrm{Mc} 14$, Mecklenburg County, and site $44 \mathrm{Ha} 6$, Halifax County, Virginia (appendix). In press.

Bastos d'Avila, José. The anthropometry of the Indians of Brazil.

\section{Beals, Ralph L.:}

Cherán: a Sierra Tarascan village

Contemporary culture of the Cáhita Indians, The. and Carrasco, Pedro, and McCorkle, Thomas.

Houses and house use of the Sierra Tarascans.

Beckwith, Martha Warren. The Hawailan romance of Laieikawai.

Belaieff, Juan. The present-day Indians of the Gran Chaco.

Belief of the Indian in a connection between song and the supernatural, The (Densmore).

Benedict, Ruth. Tales of the Cochiti Indians........

Bennett, Wendell C.:

Engineering.

IIabitations

Household furniture

Mnemonic and recording devices

Numbers, measures, weights, and calendars......

Religious structures.

The Andean Highlands: An introduction

The archeology of Colombia

The archeology of the Central Andes.

$\begin{array}{ll}\mathrm{P} & 2 . \\ \mathrm{B} & 142 . \\ \mathrm{P} & 1 .\end{array}$

143, vol. 5, pp. 6996.

41, 119 ,

182, Riv. Bas. Surv. Pap.

No. 25.

B 143, vol. 6, pp. 7184.

A $\quad 33,285$.

143, vol. 1, pp. 371 380 .

151, Anthrop. Pap. No. 37.

B 98.

B 143, vol. 5, pp. 5365.

B 143, vol. 5, pp. 120.

B 143, vol. 5, pp. 2127.

B 143, vol. 5 , pp. $611-$ 619.

B 143, vol. 5, pp. 601610.

I3 143, vol. 5, pp. 2951.

B 143, vol. 2, pp. 160.

13 143, vol. 2, pp. 823850 .

B 143, vol. 2, pp. 61147. 
Bennett, Wendell C.-Continued

The Atacameño

Bering Strait, The Eskimo about (Nelson) ......... Betoi and their neighbors, The (Hernández de Alba) -

Bibliography :

of the Algonquian languages (Pilling)

of the Athapascan languages (Pilling) ...........

of the Chinookan languages (including the Chinook jargon) (Pilling).

of the Eskimo language (Pilling)

of the Iroquoian languages (Pilling) ............ .

of the lauguages of the North American Indians,

Proof sheets of (Pilling).

of the Muskhogean languages (Pilling) ..........

of the Salishan languages (Pilling) .............

of the Siouan languages (Pilling) ................

of the tribes of Tierra del Fuego (Cooper) ........

of the Wakashan languages (Pilling) _............

Biloxi-Ofo dictionary (Dorsey and Swanton) ........-

Birchbark, Art processes in, of the River Desert Algonquin (Speck).

\section{Bird, Junius B.:}

The Alacaluf.

The archeology of Patagonia

The cultural sequence of the North Chilean Coast_

The historic inhabitants of the North Chilean Coast.

Blood groups of South American Indians (Boyd) .....

Blood revenge, war, and victory feasts among the Jibaro Indians of eastern Ecuador (Karsten).

\section{Boas, Franz:}

Chinook texts

Ethnology of the Kwakiutl Indians (based on notes by George Hunt).

Kathlamet texts

The Central Eskimo ...........

Tsimshian mythology .............

Tsimshian texts . . . . .

and Chamberlain, Alexander Francis. Kutenai tales.

editor. Handbook of American Indian languages_ See also Haeberlin, H. K.; 'Teit, James A.; and Roberts, Helen $\mathrm{H}$.

Bogoras, Waldemar. See Bulletin 40 (pt. 2).

Bolivia, eastern, Native tribes of (Métraux)

Bolivia and the Madeira headwaters, Tribes of eastern (Métraux).
B 143, vol. 2, pp. 599618.

$18,3$.

B 143, vol. 4 , pp. 393 398.

13.

14.

15.

1.

6.

2.

9.

16.

5.

63.

19.

47.

128, Anthrop Pap. No. 17.

143, vol. 1 , pp. $55-$ 79.

143 , vol. 1 , pp. 1724.

143, vol. 2, pp. 587594.

143, vol. 2, pp. 595597.

B 143, vol. 6, pp. 9195.

B 79.

20.

A 35,42 .

B 26 .

A $\quad 6,399$.

A 31, 29 .

B 27.

B 59.

B 40 .

B 134.

B 143, vol. 3, pp. 381454. 
Bolivian Andes, Tribes of the eastern slopes of the B (Métraux).

\section{Bonner jea, Biren:}

General index, annual reports of the Bureau of American Ethnology, vols. 1 to 48 .

Index to Bulletins 1-100 of the Bureau of American Ethnology. In press.

Bororo, The (Lowic)

Botocudo, The (Métraux)

Bourke, John G. The medicine-men of the Apache... Bowditch, Charles P. [Papers translated under the supervision of].

Boyd, Mark F. Historic sites in and around the Jim Woodruff Reservoir area, Florida-Georgia.

Boyd, William C. Blood groups of South American Indians.

Brand, Donald D. Quiroga: A Mexican municipio...

Brazil, Eastern: An introduction (Lowie)

Brazil, The anthropometry of the Indians of (Bastos d'Avila).

Brinton, Daniel G. The graphic system and ancient methods of the Mayas.

British Columbia, Music of Indians of (Densmore)....

British Columbia and surrounding region, Coiled basketry in (Haeberlin, Teit, and Roberts).

See also Thompson Indians.

British Columbia coast, Early vertebrate fauna of (Fisher).

British Guiana. See Roth, Walter E.

British Honduras, Archeological investigations in the Corozal District of (T. and M. Gann).

British Honduras, northern, Maya Indians of (Gann) - B

British Honduras, Report on two skulls from. (A. J. B E. Cave).

Bryan, Alan; Osborne, Douglas; and Crabtree, Robert

H. The Sheep Island site and the mid-Columbia Valley.

Buena Vista Lake, California, Archeological investigations at (Wedel).

Buena Vista sites, California, Skeletal remains from B (Stewart).

Bulkley River, The Carrier Indians of the (Jenness)...

Bullen, Ripley P. Six sites near the Chattahoochee River in the Jim Woodruff Reservoir area, Florida.

\section{Bunzel, Ruth L.:}

Introduction to Zuñi ceremonialism ..............

Zuñi katcinas: An analytical study.
143, vol. 3, pp. 465506.

A 48,25 .

B 178 .

B

143, vol. $1, \mathrm{pp} .419-$ 434.

B 143, vol. 1, pp. 531540.

9, 443 .

28.

$169,195-314$.

143, vol. 6, pp. 9195.

11.

143, vol. 1, pp. 381397.

B 143 , vol. 6 , pp. 7184.

5 (pt. 3), xvir.

B 136, Anthrop. Pap. No. 27.

41, 119.

133, Anthrop. Pap. No. 20, 133.

B 123, Anthrop. Pap. No. 7.

64.

123, Anthrop. Pap.

No. 7, pp. 59-60.

179, Riv. Bas.

Surv. Pap. No.

24.

130.

130, 172.

133, Anthrop. Pap.

No. 25.

169, 315-357.

А $47,467$.

A $\quad 47,837$. 
Bunzel, Ruth L.--Continued

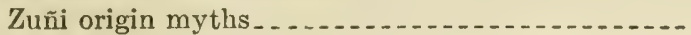

Zuñi ritual poetry

A 47,545 .

Burial, Native cemeteries and forms of, east of the Mississippi (Bushnell).

Burials, Artifacts and, Whitewater District, eastern Arizona (Roberts).

Burials of the Algonquian, Siouan, and Caddoan tribes west of the Mississippi (Bushnell).

Burton Mound at Santa Barbara, California, Exploration of the (Harrington).

Bushnell, David I., Jr.:

Burials of the Algonquian, Siouan, and Caddoan tribes west of the Mississippi.

Choctaw of Bayou Lacomb, Louisiana

Native cemeteries and forms of burial east of the Mississippi.

Native villages and village sites east of the Missis- B sippi.

Villages of the Algonquian, Siouan, and Caddoan tribes west of the Mississippi.

Butchering techniques at the Dodd and Phillips Ranch sites (White).

Byers, Douglas S. Second comment on William A. B Ritchie's "Iroquois Archeology and Settlement Patterns."

Byington, Cyrus. A dictionary of the Choctaw lan- B guage (Swanton and Halbert, editors).

Caddoan tribes:

west of the Mississippi, Burials of the Algonquian, B

Siouan, and (Bushneli).

west of the Mississippi, Villages of the Algonquian, B

Siouan, and (Bushnell).

Caddo Indians, Source material on the history and eth- B nology of the (Swanton).

Cáhita Indians, The contemporary culture of the B (Beals).

Caingang, The (Métraux)

Caldwell, Joseph R. The Rembert mounds, Elbert County, Georgia.

Caldwell, Warren W. Archeological investigations at the Coralville Reservoir, Iowa.

Calendar, The Andean (Valcárcel)

Calendar history of the Kiowa Indians (Mooney)....-Calendar systems:

Mayan (Thomas)

B 143, vol. 1, pp. 445475.

B 154, Riv. Bas. Surv. Pap. No. 6.

B 179, Riv. Bas. Surv.

Pap. No. 22.

B 143, vol. 2, pp. 471476.

A $17,129$.

A 19,693 , and 22 (pt.

$$
\text { 1), } 197 .
$$

Mayan antiquities, history, and. See Bulletin 28. Mexican and Central American (Seler and others). 
Calendars, Numbers, measures, weights and (Bennett)_ B

California:

Archeological investigations at Buena Vista Lake, B Kern County (Wedel).

Buena Vista sites, Skeletal remains from (Stewart) _

Handbook of Indians of (Kroeber) ..............

Perforated stones from (Henshaw) ............. B

'Tribes of (Powers) ..........................

See also Harrington, John P.

Camacan linguistic family, The (Métraux and Nimuendajú).

\section{Canals Frau, Salvador:}

The expansion of the Araucanians in Argentina...

The Huarpe

Cannibalism, and human trophies, Warfare (Métraux).

Capron, Louis. The medicine bundles of the Florida Seminole and the Green Corn Dance.

Carajá, The (Lipkind)

Carib, The (Rouse)

Caribbean Lowland tribes, 'The: The Mosquito, Sumo, Paya, and Jicaque (Kirchhoff).

Caribbean Lowland tribes, The: The Talamanca Divi- B sion (Johnson).

Caribs of Dominica, The ('Taylor)

Cariri, The (Lowie)

Caroline Islands script, A (Riesenberg and Shigeru)

Carrasco, Pedro; Beals, Ralph L.; and McCorkle, Thomas. Houses and house use of the Sierra Tarascans.

Carrier Indians of the Bulkley River (Jenness) ........

Carter, John G. The northern Arapaho flat pipe and the ceremony of covering the pipe.

Carvings, Animal, from mounds of the Mississippi Valley (Henshaw).

Casa Grande, Arizona (Fewkes)

Casa Grande ruin (C. Mindeleff) ................. The repair of, in 1891 (C. Mindeleff)

Casanova, Eduardo. The cultures of the Puna and the Quebrada de Humahuaca.

Castro Pozo, Hildebrando. Social and economico-political evolution of the communities of Central Perú.
143 , vol. 5 , pp. $601-$ 610.

130.

130, 172 .

78.

2.

3.

B 143 , vol. 1, pp. $547-$ 552.

143, vol. 2, pp. 761766 .

143 , vol. 1 , pp. $169-$ 175.

B 143, vol. 5 , pp. 383409.

151, Anthrop. Pap. No. 35.

143 , vol. 3 , pp. 179 191.

143, vol. 4, pp. 547565.

143, vol. 4, pp. 219 229.

143, vol. 4, pp. 231251.

119, Anthrop. Pap. No. 3.

143, vol. 1, pp. 557559.

B 173, Anthrop. Pap. No. 60 .

1.

B 133, Anthrop. Pap. No. 25.

B 119, Anthrop. Pap. No. 2.

A 2,117 .

A 28,25 .

A 13,289 .

A 15,315 .

B 143, vol. 2, pp. 619631.

B 143, vol. 2, pp. 483499. 
Catalogue:

Illustrated, of collections from New Mexico and A 2, 307. Arizona in 1879 (J. Stevenson).

Illustrated, of collections from New Mexico in 1880 (J. Stevenson).

Illustrated, of collections from pueblos in 1881 (J. A $\quad 3,511$. Stevenson).

Illustrated, of collections made in 1881 (Holmes) _- A $\quad 3,427$.

of linguistic manuscripts in the library of the $\mathrm{Bu}-\mathrm{A} \quad 1,553$. reau of Ethnology (Pilling).

of prehistoric works east of the Rocky Mountains B (Thomas).

Cauca Valley, Sub-Andean tribes of the (Hernández de B Alba).

Cave, A. J. E. Report on two skulls from British Hon- B duras.

Cave explorations in other States (Fowke)

12.

Cave explorations in the Ozark region of Central Mis- B souri (Fowke).

Caves, Ancient, of the Great Salt Lake region (Stew- B ard).

Cawahíb, Parintintin, and their neighbors, The (Nimu- B endajú).

Cayabí, Tapanyuna, and Apiacá, The (Nimuendajú)_- B

Cayapa and Colorado, The (Murra)

143, vol. 4, pp. 297327.

123, Anthrop. Pap. No. 7, pp. 59-60.

76, 101 .

$76,13$.

116.

143, vol. 3, pp. 283297.

143, vol. 3 , pp. $307-$ 320 .

B 143, vol. 4, pp. 277291.

Cayapo, The Southern (Lowie)

Cegiha language, The (Dorsey)

Cemeteries, Native, and forms of burial east of the Mis- B 71 . sissippi (Bushnell).

See also Burials.

Central America:

Anthropological needs and possibilities in (Strong B and Johnson).

Cultivated plants of South and (Sauer)......... B

Indian languages of Mexico and (Thomas and B Swanton).

Numeral systems of Mexico and (Thomas) _...... A

The archeology of: An introduction (Strong) _.... B

The basic cultures of (Stone) .............. B

The post-Conquest ethnology of: An introduction B (Johnson).

See also British Honduras; Yucatan.

Central American, and Mexican antiquities, calendar B systems, and history (Seler and others).

Central American cultures: An introduction (Johnson)_ B

143, vol. 1, pp. 519520 .

71.

143, vol. 4, pp. 293296.

143 , vol. 6 , pp. $319-$ 344 .

44.

$19,853$.

143, vol. 4, pp. 6970 .

143, vol. 4, pp. 169193.

143, vol. 4, pp. 195198.

28.

143, vol. 4, pp. 4368.

$615214-62-5$ 
Central American picture-writing, Studies in (Holden)-

Central Andes, The archeology of the (Bennett) ......

Central Perú, Social and economico-political evolution of the communities of (Castro Pozo).

Cephalic deformations of the Indians in Argentina $B$ (Imbelloni).

Ceramic remains from two sites near Beaufort, South B Carolina (Griffin).

Ceramics (Willey)

Ceramic sequences at Tres Zapotes, Veracruz, Mexico (Drucker).

Ceramics of Tres Zapotes, Veracruz, Mexico, An introduction to the (Weiant).

Ceramic stratigraphy at Cerro de las Mesas, Veracruz, B Mexico (Drucker).

Ceramic study of Virginia archeology, A (Evans) .....

Ceremonialism, Zuñi, Introduction to (Bunzel)

Ceremonial life of the Choctaw Indians, Source material for the social and (Swanton).

Ceremonial of Hasjelti Dailjis and mythical sand painting of the Navajo (J. Stevenson).

Ceremonies, Tonawanda longhouse, ninety years after Lewis Henry Morgan (Fenton).

Ceremonies, Tusayan snake (Fewkes) ..............

Ceremony, The Hako: A Pawnee (A. C. Fletcher) -...

Ceremony, War, and peace ceremony (La Flesche)...

Ceremony of covering the northern Arapaho flat pipe (Carter).

Cerro de las Mesas, Mexico, ceramic stratigraphy (Drucker).

Cerro de las Mesas offering of jade and other materials, The (Drucker).

Cessions, Indian land, in the United States (Royce and Thomas).

Cessions of land by Indian tribes to the United States (Royce).

Chaco, Ethnography of the (Métraux) ...............

Chaco Canyon. See Roberts, Frank H. H., Jr.

Chaco-Santiagueño culture, The (Márquez Miranda) - -

Chafe, Wallace L.

Comment on Anthony F. C. Wallace's "Cultural

Composition of the Handsome Lake Religion."

Seneca Thanksgiving rituals.

Chama Valley, New Mexico, Excavation in the (Jencon).

Chamberlain, Alexander Francis, and Boas, Franz, B Kutenai tales.

Change, persistence, and accommodation in Cherokee $B$ medico-magical beliefs (Fogelson).
$1,205$.

143, vol. 2, pp. 61147.

143, vol. 2, pp. 483499.

143, vol. 6, pp. 5355.

133, Anthrop. Pap. No. 22.

143, vol. 5, pp. $139-$ 204.

140.

139.

141.

160.

47,467 .

103.

8, 229.

128, Anthrop. Pap. No. 15.

16, 267.

22 (pt. 2), 5.

101.

119, Anthrop. Pap. No. 21.

141.

157, 25-68.

$18,521$.

$1,247$.

143, vol. 1, pp. 197370.

B 143, vol. 2, pp. 655660 .

B 180,pp. 153-157.

183.

81.

59.

180, pp. 213-225. 
Charrua, The (Serrano)

Cherán: a Sierra Tarascan village (Beals)

Cherokee, Myths of the (Mooney)

Cherokee, The sacred formulas of the (Mooney)

Cherokee archeology (Coe)

Cherokee economic cooperatives: The Gadugi (Fogelson and Kutsche).

Cherokee nation of Indians, The (Royce)

Cherokee sacred formulas and medicinal prescriptions, The Swimmer manuscript: (Mooney and Olbrechts).

Cherokees, the Eastern (Gilbert)

Chibcha, The (Kroeber)

Chickasaw Indians, Social and religious beliefs and usages of the (Swanton).

Children's stories, with texts and songs, Picuris (Harrington).

Chile:

The Diaguita of (Lothrop)

The geographical pathology of (Herzog)

The Indians of, The anthropometry of (Henckel).

The races of, The physical anthropology of the internal organs among (Henckel).

Chinookan languages (including the Chinook jargon), Bibliography of the (Pilling).

See also Bulletin 40 (pt. 1).

Chinook Texts (Boas)

Chippewa child life and its cultural background (Hilger).

Chippewa customs (Densmore)

Chippewa Indians, Uses of plants by the (Densmore) ...

Chippewa music (Densmore)

Chippewa music-II (Densmore)

See also Ojibwa.

Chiriqui, Colombia, Ancient art of the province of (Holmes).

Chiriqui, Isthmus of Darien, The use of gold and other metals among the ancient inhabitants of (Holmes).

Chitimacha Indians in Louisiana, A search for songs among the (Densmore).

Chitimacha language. See Bulletin 68.

Choco, The (Stout)

Choctaw Indians, Source material for the social and ceremonial life of the (Swanton).

Choctaw language, A dictionary of the (Byington) (Swanton and Halbert, editors).
143, vol. 1, pp. 191196.

2.

A $\quad 19,3$.

A 7,301.

B 180, pp. 51-60.

B 180, pp. 83-123.

A 5, 121 .

B 99.

B 133, Anthrop. Pap. No. 23.

B 143, vol. 2, pp. 887909.

A 44,169 .

A $43,289$.

B 143, vol. 2, pp.

633-636.

B 143, vol. 6, pp.

137-144.

B 143, vol. 6 , pp. 121-

135.

B 143 , vol. 6 , pp. 145 156.

B 15 .

B 20 .

B 146 .

B 86 .

A 44,275 .

B 45 .

B 53 .

A 6,3 .

B 3 .

B 133, Anthrop. Pap. No. 19.

B 143, vol. 4, pp. 269276.

B 103 .

B 46 . 
Choctaw music (Densmore)

Choctaw of Bayou Lacomb, Louisiana (Bushnell)

Chono, The (Cooper)

Chukchee (Bogoras). See Bulletin 40 (pt. 2).

Cibola architecture (V. Mindeleff) See also Zuñi.

Ciboney, The (Rouse)

Ciboney, The ethnology of the (García Valdés)

Ciguayo. The ethnography of Hispaniola

Circum-Caribbean tribes, The: An introduction (Steward).

Clans, Tusayan, Localization of (C. Mindeleff)

Cliff Palace, Mesa Verde National Park [Colorado] (Fewkes),

Cliff ruins of Canyon de Chelly, Arizona (C. Mindeleff) Coaiquer, The modern Quillacinga, Pasto and (Ortíz) _-

Cochiti Indians, Tales of the (Benedict)

Coconuco, The Moguex- (Lehmann)

Codices, Maya, Aids to the study of the (Thomas) -...-

Coe, Joffre, L. Cherokee archeology ...............

Coiled basketry in British Columbia and surrounding region (Haeberlin, Teit, and Roberts).

Collections:

Illustrated catalogue of, from New Mexico and Arizona in 1879 ( $\mathrm{J}$. Stevenson).

from New Mexico in 1880 (J. Stevenson) _.......

from pueblos in 1881 (J. Stevenson)

made in 1881 (Holmes)

Collier, Donald. The archeology of Ecuador -

Colombia:

The archeology of (Bennett)

The archeology of San Agustín and Tierrodentro (Hernández de Alba).

The Highland tribes of southern (Hernández de Alba).

The native tribes and languages of southwestern (Ortíz).

Colorado:

Antiquities of the Mesa Verde: Cliff Palace B (Fewkes).

Antiquities of the Mesa Verde: Spruce-tree House B (Fewkes).

Antiquities of the region between the Mancos and A La Plata Rivers (Morris).
B 136, Anthrop. Pap. No. 28.

B 48 .

B 143, vol. 1, pp. 4754.

A 8,3 .

B 143, vol. 4, pp. 497503.

B 143, vol. 4, pp. 503505.

B 143, vol. 4, p. 539.

B 143, vol. 4, pp.

$$
1-41 \text {. }
$$

A 19,635.

B 51 .

A 16,73 .

B 143, vol. 2, pp. 961968.

98.

B 143 , vol. 2, pp. $969-$ 974.

A 6, 253.

B 180, pp. 51-60.

41, 119.

A 2, 307 .

A 2, 423 .

A 3,511.

A 3,427 .

B 143, vol. 2, pp. 767784.

B 143, vol. 2, pp. 823850.

143, vol. 2 , pp. 851859.

143, vol. 2, pp. 915961.

143, vol. 2, pp. 911914.

51.

41.

33, 155. 
Colorado-Continued

Prehistoric villages, castles, and towers of south- B western (Fewkes).

See also Roberts, Frank H. H., Jr.

Colorado, The Cayapa and (Murra)

Colton, Harold S. A survey of prehistoric sites in the B region of Flagstaff, Arizona.

Comechingón and their neighbors of the Sierras de Cór- B doba, The (Aparicio).

Comment on Anthony F. C. Wallace's "Cultural Com- B position of the Handsome Lake Religion" (Chafe).

Comment on Floyd G. Lounsbury's "Iroquois-Cherokee Linguistic Relations" (Haas).

Comment on Fred O. Gearing's "The Rise of the Cherokee State as an Instance in a Class: The 'Mesopotamian Career' to Statehood" (Shimony).

Comment on Gertrude P. Kurath's "Effects of Environment on Cherokee-Iroquois Ceremonialism, Music, and Dance" (Sturtevant).

Comment on Jofîre L. Coe's "Cherokee Areheology" (Fairbanks).

Comment on John Witthoft's "Eastern Woodlands Community Typology and Acculturation" (Goggin).

Comment on Robert K. Thomas's "The Redbird Smith Movement" (Voget).

Concept of locality and the program of Iroquois research, Introduction: (Fenton).

Concepts of land ownership among the Iroquois and their neighbors (Snyderman).

Connecticut, Native tribes and dialects of (Speck) -...-

Contributions to Fox ethnology (Michelson) ...........

Contributions to Fox ethnology-II (Michelson) _.....

Conzemius, Eduard. Ethnographical survey of the Miskito and Sumu Indians of Honduras and Nicaragua.

\section{Cooper, John M.:}

Analytical and critical bibliography of the tribes of Tierra del Fuego and adjacent territory.

Fire making

Games and gambling

Stimulants and narcotics

The Araucanians

The Chono

The Ona

The Patagonian and Pampean Hunters.
70.

143, vol. 4, pp. 277291.

104.

143, vol. 2, pp. 673685.

180, pp. 153-157.

180, pp. 9-17.

180, pp. 125-134.

B

180, pp. 173-197.

B

180, pp. 61-65.

B 180, pp. 77-81.

B 180,pp. 167-171.

B 149, 1-12.

B $\quad 149,13-34$.

A $43,199$.

B 85 .

B 95 .

B 106 .
B

B

\section{B}

B

B

B

B

B
63.

143, vol. 5, pp. 283292.

143, vol. 5, pp. 503524.

143, vol. 5, pp. 525558.

143, vol. 2, pp. 687760 .

143 , vol. 1 , pp. 4754.

143, vol. 1, pp. $107-$ 125.

143, vol. 1, pp. 127168. 
Cooper, John M.-Continued

The Southern Hunters: An introduction.

The Yahgin.

Traps

Cooper, Paul L. Archeological investigations in the Heart Butte Reservoir area, North Dakota.

Copper artifacts from the MeNary site, Oregon, Examination of (appendix 4).

Coronado expedition, 1540-1542, The (Winship) _.....-

Cosmology: Iroquoian (Hewitt) ...................

Cosmology, Iroquoian, second part, with introduction and notes (Hewitt).

Costa Rica and Nicaragua, The archeology of (Strong) -

Couvade, The (Métraux)

Crabtree, Robert H.; Osborne Douglas; and Bryan, Alan. The Sheep Island site and the Mid-Columbia Valley.

Cree and Montagnais-Naskapi dialects, Linguistic classification of (Michelson).

Creek Confederacy, Social organization and social usages of the Indians of the (Swanton).

Creek Indians and their neighbors, Early history of the (Swanton).

Creek Indians, Notes on the (Hewitt)

Creek Indians, Religious beliefs and medical practices of (Swanton).

Crow-Flies-High (32MZ1), a historic Hidatsa village in the Garrison Reservoir Area, North Dakota. In press.

Cruz das Almas: a Brazilian village (Pierson) ........

Culbertson, Thaddeus A. Journal of an expedition to the Mauvaises Terres and the Upper Missouri in 1850 (edited by John Francis MeDermott).

Culin, Stewart. Games of the North American Indians. Cults, Siouan, A Study of (Dorsey) _................

Cultural and historical geography of southwest Guatemala (McBryde).

Cultural composition of the Handsome Lake Religion (Wallace).

Cultural geography of the modern Tarascan area (West).

Cultural sequence of the North Chilian Coast, The (Bird).

Culture, Aboriginal, of the Southeast (Swanton) .......

Culture areas of the Tropical Forests (Steward) .......
143 , vol. 1 , pp. $13-$

15.

B 143, vol. 1, pp. 81106.

143 , vol. 5, pp. 265276.

169, 5-40.

166.

A 14, 329 .

A $21,127$.

A 43, 449 .

B 143, vol. 4, pp. 121142.

B 143, vol. 5, pp. 369374.

B 179, Riv. Bas. Surv. Pap. No. 24.

B

123, Anthrop. Pap. No. 8.

A $\quad 42,23$.

B 73.

B 123, Anthrop. Pap. No. 10.

A $\quad 42,473$.

B 185, Riv. Bas. Surv. Pap. No. 29.

P 12.

B 147.

A 24,3 .

A 11, 351 .

P 4.

B 180, pp. 139-151.

7.

B 143, vol. 2, pp. 587594.

A 42,673.

B 143, vol. 3, pp. 883899. 
Cultures, Central American: An introduction (John- B son).

Cultures, South American: An interpretative summary (Steward).

Culture sequence for the North Coast of Perú, A (Larco Hoyle).

Cultures of Central America, The basic (Stone)

Cultures of the Puna and the Quebrada de Humahuaca, B The (Casanova).

Cumming, Robert B. Archeological investigations at $B$ the Tuttle Creek Dam, Kansas.

Cuna, The (Stout)

Cup-shaped and other lapidarian sculptures (Rau) _...-

Current trends in the Wind River Shoshone Sun Dance (Voget).

Curtin, Jeremiah, and Hewitt, J. N. B. Seneca fiction, legends, and myths (edited by J. N. B. Hewitt).

Curtis, Garniss H. The petrology of artifacts and $B$ architectural stone at La Venta (appendix 4).

\section{Cushing, Frank Hamilton:}

Outlines of Zuñi creation mythe

Pueblo pottery as illustrative of Zuñi culture growth.

Zuñi fetiches

Cuzco archeology (Valcárcel)

Dakota-English dictionary, A (Riggs)

Dakota grammar, texts, and ethnography (Riggs) _... See also Siouan.

Dakota winter counts as a source of Plains history (Howard).

Dall, William H.:

On masks, labrets, and certain aboriginal customs _ Terms of relationship used by the Innuit........ Tribes of the extreme Northwest. .............. and Gibbs, George. Vocabularies of tribes of the extreme Northwest.

Dance hall of the Santee Bottoms on the Fort Berthold Reservation, Garrison Reservoir, North Dakota, The (Hartle). In press.

Dangberg, Grace M., editor. Letters to Jack Wilson, the Paiute Prophet, written between 1908 and 1911.

Day symbols of the Maya year (Thomas)

Deardorff, Merle H. See Fenton, William N., editor.

Deformations, Cephalic, of the Indians in Argentina (Imbelloni).

Deformity, trephining, and mutilation in South American Indian skeletal remains (Stewart).

DeJarnette, David L. See Webb, William S., and DeJarnette.
143 , vol. 4 , pp. 4368.

143, vol. 5, pp. 669772.

143, vol. 2, pp. 149175.

143, vol. 4 , pp. $169-$ 193.

143, vol. 2, pp. 619631.

$169,41-78$.

B 143, vol. 4, pp. 257268.

C 5 .

B 151, Anthrop. Pap. No. 42.

32,37 .

170.

A 13, 321.

A 4,467 .

A. 2,3 .

B 143 , vol. 2, pp. 177182.

C 7.

C 9.

B 173, Anthrop. Pap. No. 61.

A 3,67 .

C 1,117 .

C 1,1 .

C 1,121.

B

185, Riv. Bas. Surv. Pap. No. 28.

B 164, Anthrop. Pap. No. 55.

A 16, 199 .

B 143, vol. 6, 53-55.

B 143, vol. 6, 43-48. 
Delawares, Physical anthropology of the Lenape or B (Hrdlička).

\section{Denig, Edwin T.:}

Indian tribes of the Upper Missouri (edited by $\Lambda \quad \mathbf{4 6 , 3 7 5}$.

J. N. B. Hewitt).

Of the Crow Nation (edited by John C. Ewers) _. B B 151, Anthrop. Pap.

\section{Densmore, Frances:}

A search for songs among the Chitimacha Indians in Louisiana.

Chippewa customs........

Chippewa music

Chippewa music-II_._.

Choctaw music.

Mandan and Hidatsa music ...............

Menominee music

Music of Acoma, Isleta, Cochiti, and Zuñi Pueblos

Music of the Indians of British Columbia

Nootka and Quileute music .................

Northern Ute music . . . . . . . . . . . . . . . . .

Papago music ...........

Pawnee music ...

Seminole music_._.

Technique in the music of the American Indian.-

Teton Sioux music

The belief of the Indian in a connection between song and the supernatural.

Uses of plants by the Chippewa Indians_........

Yuman and Yaqui music ...................

Designs on prehistoric Hopi pottery (Fewkes) _.......

Devereux, George. Mohave ethnopsychiatry and suicide: The psychiatric knowledge and the psychic disturbances of an Indian tribe.

Diaguita of Argentina, The (Márquez Miranda)......

Diaguita of Chile, The (Lothrop)

Dialects, Linguistic classification of Cree and Montagnais-Naskapi (Michelson).

Dialects of Connecticut, Native tribes and: A MoheganPequot diary (Speck).

Dick, Herbert W. Two rock shelters near Tucumcari, New Mexico.

Dictionary:

Biloxi-Ofo (Dorsey and Swanton)

B 133, Anthrop. Pap. No. 19.

\section{B 86 .}

B 45.

B 53.

$B$ 136, Anthrop. Pap. No. 28.

B 80 .

B 102 .

B 165 .

B 136, Anthrop. Pap. No. 27.

B 124.

B 75 .

B 90 .

B 93.

B 161.

B 151, Anthrop. Pap. No. 36.

B 61 .

B 151, Anthrop. Pap. No. 37.

A 44, 275 .

B 110,

A 33, 207.

B 175 .

B 143, vol. 2, pp. 637654.

B 143, vol. 2, pp. 633636.

B 123, Anthrop. Pap. No. 8.

A 43, 199.

B 154, Riv. Bas. Surv. Pap. No. 5, Pt. 1.

Choctaw (Byington; Swanton and Halbert, B 46. editors)

Dakota-English (Riggs)

C 7. 
Dictionary-Continued

Guaymi grammar and, with some ethnological B 162. notes.

Natick

Niskwalli (Gibbs)

B 25.

of American Indians north of Mexico. Advance pages (Hodge).

of the Atakapa language (Gatschet and Swanton).-

of the Osage language (La Flesche)

C 1 (pt. 2), 285.

M 6.

B 108.

B 109 .

Dieseldorff, E. P., and others. Mexican and Central B 28.

American antiquities, calendar systems, and history.

Diné, The: Origin myths of the Navaho Indians (O'Bryan)

Dixon, Roland B. See Bulletin 40 (pt. 1).

Dominica, The Caribs of (Taylor)

B 163.

Dorsey, James Owen:

Method of recording Indian languages............

Omaha and Ponka letters....................

Omaha dwellings, furniture, and implements.....-

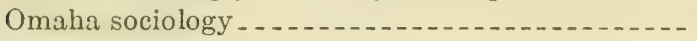

Osage traditions_............

Siouan sociology _...

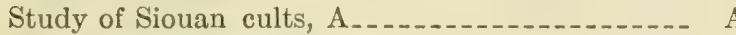

The Cegiha language.........................

and Swanton, John R. A dictionary of the Biloxi and Ofo languages.

editor-

A Dakota-English dictionary, by S. R. Riggs _

Dakota grammar, texts, and ethnography, by S. R. Riggs.

\section{Drucker, Philip :}

Archeological survey on the northern Northwest Coast.

Ceramic sequences at Tres Zapotes, Veracruz, Mexico.

Ceramic stratigraphy at Cerro de las Mesas, Veracruz, Mexico.

La Venta, Tabasco: A study of Olmec ceramics and art. With a chapter on structural investigations in 1943 (Wedel), and appendix on technological analyses (Shepard).

The Cero de las Mesas offering of jade and other materials.

The Native Brotherhoods: Modern intertribal organizations on the Northwest Coast.

The Northern and Central Nootkan tribes....... and Heizer, Robert F., and Squier, Robert J. Excavations at La Venta, Tabasco, 1955. With appendixes by Jonas E. Gullberg, Garniss H. Curtis, and A. Starker Leopold.

Dwellings, furniture, and implements, Omaha (Dorsey). See also Houses.

B 119, Anthrop. Pap. No. 3.

$\begin{array}{ll}\text { A } & 1,579 . \\ \text { B } & 11 . \\ \text { A } & 13,263 . \\ \text { A } & \mathbf{3}, 205 . \\ \text { A } & 6,373 . \\ \text { A } & 15,205 . \\ \text { A } & \mathbf{1 1}, 351 . \\ \text { C } & 6 . \\ \text { B } & 47 .\end{array}$

C 7.

C 9.

B 133, Anthrop. Pap. No. 20.

B 140.

B 141.

B 153.

B 157, Anthrop. Pap. No. 44.

B 168.

B 144.

B 170 .

A $13,263$. 
Early history of the Creek Indians and their neighbors

73. (Swanton).

Early man. See Man, early.

Early Pueblo ruins in the Piedra district, southwestern Colorado (Roberts).

Earthworks, the circular, square, and octagonal, of B Ohio (Thomas). Eastern Indians, Physical anthropology of the (Hrd-
lička).

Eastern Woodlands community typology and acculturation (Witthoft).

Economics, primitive, A study in American. The wild rice gatherers of the Upper Lakes: (Jenks).

Ecuador, Eastern, Blood revenge, war, and victory feasts among the Jibaro Indians of (Karsten).

Ecuador, Province of Imbabura, The Quichua-speaking Indians of (Gillin).

Ecuador, The archeology of (Collier)

Ecuador, The historic tribes of (Murra)

Effects of environment on Cherokee-Iroquois ceremonialism, music, and dance (Kurath).

Eliot's Indian Bible. See Bulletin 13.

Emerson, N. B. Unwritten literature of Hawaii......

Empire's children: the people of Tzintzuntzan (Foster and Ospina).

Engineering (Bennett)

Eskimo, Central, The (Boas)

See also Point Barrow; Ungava district.

Eskimo about Bering Strait, The (Nelson)

Eskimo language, Bibliography of the (Pilling) See also Bulletin 40 (pt. 1).

Esthetology, or the science of activities designed to give pleasure (Powell).

Ethnobotany:

of the Tewa Indians (Robbins, Harrington, and Freire-Marreco).

of the Thompson Indians of British Columbia (Steedman).

of the Zuñi Indians (M. C. Stevenson) ......... See also Plants.

Ethnography of Hispaniola, The (Ciguayo) _........

Ethnography of Hispaniola, The (Taino)

Ethnogeography of the Tewa Indians (Harrington) -..

Ethnographical material on the Jivaro Indians, Historical and (Stirling).

Ethnographical survey of the Miskito and Sumu Indians of Honduras and Nicaragua (Conzemius).

Ethnography, grammar, and texts, Dakota (Riggs) ...

B 96.

10.

62.

B $\quad 180$, pp. 67-76.

A $\quad 19,1013$.

B 79.

B

128, Anthrop. Pap.

No. 16.

B 143, vol. 2, pp. 767-

784.

B 143, vol. 2, pp. 785-

821.

B 180, pp. 173-195.

B 38.

P 6.

B 143 , vol. 5 , pp. 53-

65.

A 6,399 .

A 18 (pt. 1), 3.

B 1 .

A $19, \mathrm{Lv}$.

B 55 .

A 45,441 .

A $\quad 30,31$.

B 143, vol. 4, p. 539 .

B 143, vol. 4, pp. 522539.

A $29,29$.

B 117.

B 106.

C 9. 
Ethnography of Puerto Rico, The (Hostos)

Ethnography of the Chaco (Métraux)

Ethnography of the Fox Indians (Jones)

Ethnology:

of Central America, The post-Conquest: An introduction (Johnson).

of the Caddo Indians, Source material on the history and (Swanton).

of the Ciboney, The (García Valdés)

of the Kwakiutl (Hunt and Boas)

of the Ungava district (Turner) _..............

Ethnopsychiatry and suicide, Mohave: The psychiatric knowledge and psychic disturbances of an Indian tribe (Devereux).

Ethnozoology of South America, Fauna and (Gilmore)_ B

Ethnozoology of the Tewa Indians (Henderson and B

Harrington).

Evans, Clifford:

A ceramic study of Virginia archeology. With B $\mathbf{1 6 0}$. appendix, An analysis of projectile points and large blades (Holland).

and Meggers, Betty J.

Archeological investigations at the mouth of the Amazon.

Archeological investigations in British Guiana, B South America.

Evolution of language (Powell)

Ewers, John C.:

Hair pipes in Plains Indian adornment, a study in Indian and White ingenuity.

The horse in Blackfoot Indian culture, with com- $B$ parative material from other western tribes.

editor. Of the Crow Nation, by Edwin Thompson B Denig.

Excavation of a site at Santiago Ahuitzotla, D. F. B Mexico (Tozzer).

Excavations at La Venta, Tabasco, 1955 (Drucker, B

Heizer, and Squier). With appendixes by Jonas E.

Gullberg, Garniss H. Curtis, and A. Starker Leopold.

Excavations at Texarkana Reservoir, Sulphur River, 13

Texas (Jelks).

Excavations in the Chama Valley, New Mexico B (Jeancon).

Excavations in the MeNary Reservoir Basin near B Umatilla, Oregon (Osborne).

Exploration of an Adena Mound at Natrium, West B Virginia (Solecki).

Exploration of the Burton Mound at Santa Barbara, A California (Harrington).
143, vol. 4, pp. 540542.

143, vol. 1, pp. 197370.

125.

143, vol. 4, pp. 195198.

132.

143, vol. 4, pp. 503505 .

$35,43$.

11, 159.

175.

143, vol. 6, pp. 345464.

56.

167.

177.

1,1 .

164, Anthrop. Pap. No. 50 .

159.

151, Anthrop. Pap. No. 33.

74.

170.

179, Riv. Bas. Surv.

81.

$$
\text { Pap. No. } 21 .
$$

166.

151, Anthrop. Pap.

No. 40.

44, 23. 
Explorations along the Missouri River Bluffs in Kansas and Nebraska (Fowke).

Explorations, archeological, at Macon, Ga. (Kelly)----

Expression, Philology, or the science of activities designed for (Powell).

Face and body painting of the Thompson Indians, British Columbia, Tattooing and (Teit).

Factionalism at Taos Pueblo, New Mexico (Fenton) - -

Fairbanks, Charles H. Comment on Joffre L. Coe's B "Cherokee Archeology."

Fairs in Perú, Indian markets and (Valcárcel)

Fauna, early vertebrate, of British Columbia coast (Fisher).

Fauna and ethnozoology of South America (Gilmore) --

Feast of the Dead, or Ghost Dance, at Six Nations Reserve, Canada, The (Fenton and Kurath).

Fenner, Clarence N. (collaborator). Early man in South America.

\section{Fenton, William N.:}

Factionalism at Taos Pueblo, New Mexico

Iroquoian culture history: A general evaluation

Iroquois suicide: A study in the stability of a culture pattern.

The Iroquois Eagle Dance, an offshoot of the Calumet Dance. With an analysis of the Iroquois Eagle Dance and songs, by Gertrude Prokosch Kurath.

Tonawanda longhouse ceremonies: Ninety years after Lewis Henry Morgan.

editor. Symposium on local diversity in Iroquois eulture.

No. 1. Introduction: The concept of locality and the program of Iroquois research (Fenton).

No. 2. Concepts of land ownership among the Iroquois and their neighbors (Snyderman).

No. 3. Locality as a basic factor in the development of Iroquois social structure (Fenton),

No. 4. Some psychological determinants of culture change in an Iroquoian community (Wallace).

No. 5. The religion of Handsome Lake: Its origin and development (Deardorfi).

No. 6. Local diversity in Iroquois music and dance (Kurath).
B $76,151$.

B 119, Anthrop. Pap. No. 1.

A 20, Cxxxix.

45,397 .

B 164, Anthrop. Pap. No. 56.

180, pp. 61-65.

B 143 , vol. 2, pp. 477482.

133, Anthrop. Pap. No. 20, p. 133.

B 143, vol. 6, pp. 345464.

B $\quad 149,139-165$.

B 52.

B 164, Anthrop. Pap. No. 56.

B 180, pp. 253-277.

B 128, Anthrop. Pap. No. 14.

B 156, pp. 1-222.

B 128, Anthrop. Pap. No. 15.

B 149 . 


\section{Fenton, William N.-Continued}

editor. Symposium on local diversity in Iroquois culture - Continued

No.7. The Feast of the Dead, or Ghost Dance, at Six Nations Reserve, Canada (Fenton and Kurath).

No. 8. Iroquois women, then and now (Randle).

and Gulick, John (editors). Symposium on Chero- B 180. kee and Iroquois culture.

No. 1. Foreword by the editors.

No. 2. Iroquois-Cherokee linguistic relations (Lounsbury).

No. 3. Comments on Floyd G. Lounsbury's "Iroquois-Cherokee linguistic relations (Haas).

No. 4. Iroquois archeology and settlement patterns (Ritchie).

No. 5. First comment on William A. Ritchie's "Iroquois Archeology and Settlement Patterns" (Sears).

No.6. Second comment on William A. Ritchie's "Iroquois Archeology and Settlement Patterns" (Byers).

No. 7. Cherokee archeology (Coe).

No. 8. Comments on Joffre L. Coe's "Cherokee Archeology" (Fairbanks).

No.9. Eastern Woodlands Community typology and acculturation (Witthoft).

No. 10. Comment on John Witthoft's "Eastern Woodlands Community Typology and Acculturation" (Goggin).

No. 11. Cherokee economic cooperatives: the Gadugi (Fogelson and Kutsche).

No. 12. The rise of the Cherokee state as an instance in a class: The "Mesopotamian" career to statehood (Gearing).

No. 13. Comment on Fred O. Gearing's "The Rise of the Cherokee State as an Instance in a Class: The Mesopotamian Career to Statehood" (Shimony).

No. 14. Cultural composition of the Handsome Lake religion (Wallace).

No. 15. Comment on Anthony F. C. Wallace's "Cultural Composition of the Handsome Lake Religion" (Chafe).

No. 16. The Redbird Smith Movement (Thomas). 
Fenton William N.-Continued

and Gulick, John (editor) Symposium on Cherokee and Iroquois culture-Continued

No. 17. Comment on Robert K. Thomas's "The Redbird Smith Movement" (Voget).

No. 18. Effects of environment on CherokeeIroquois ceremonialism, music and dance (Kurath).

No. 19. Comment on Gertrude P. Kurath's "Effects of Environment on Cherokee-Iroquois Ceremonialism, Music, and Dance" (Sturtevant).

No. 20. The Iroquois fortunetellers and their conservative influence (Shimony).

No. 21. Change, persistence, and accommodation in Cherokee medico-magical Beliefs (Fogelson).

No. 22. Some observations on the persistence of aboriginal Cherokee personality traits (Holzinger).

No. 23. First comment on Charles H. Holzinger's "Some Observations on the Persistence of Aboriginal Cherokee Personality Traits" (Landy).

No. 24. Second comment on Charles H. Holzinger's "Some Observations on the Persistence of Aboriginal Cherokee Personality Traits" (Gulick).

No. 25. Iroquoian culture history: A General evaluation (Fenton).

Fetiches, Zuñi (Cushing)

Fewkes, Jesse Walter:

Aborigines of Porto Rico and neighboring islands.

Antiquities, Certain, of eastern Mexico.

Antiquities of Mesa Verde National Park: Cliff Palace.

Antiquities of Mesa Verde National Park: Sprucetree House.

Antiquities of the upper Verde River and Walnut Creek Valleys, Arizona.

Archeological expedition to Arizona in 1895 ......

Casa Grande, Arizona..................... A

Designs on prehistoric Hopi pottery ............ A

Hopi katcinas, drawn by native artists ...........

Prehistoric island culture area of America, A _.... A

Prehistoric villages, castles, and towers of southwestern Colorado.

Preliminary report on Navaho National Monument, Arizona.

Tusayan Flute and Snake ceremonies_......... A

Tusayan katcinas.......................... A

Tusayan migration traditions . . .

A 25,3 .

A $25,221$.

B 51 .

B 41 .

$28,181$.

17,519 .

$28,25$.

$33,207$.

21, 3.

34, 35 .

70.

50.

A 19,957 .

A 15,245 .

A 19, 573 . 
Fewkes, Jesse Walter-Continued

Tusayan Snake ceremonies

Two summers' work in pueblo ruins

Fiction, legends, and myths, Seneca (Curtin and Hewitt).

Fire making (Cooper)

First comment on Charles H. Holzinger's "Some Observations on the Persistence of Aboriginal Cherokee Personality Traits" (Landy).

First comment on William A. Ritchie's "Iroquois Archeology and Settlement Patterns" (Sears).

Fisher, Edna. Early vertebrate fauna of the British Columbia coast (appendix).

Fisher, Margaret Welpley (editor). Ethnography of the Fox Indians (Jones).

Fish poisons (Heizer)

Flagstaff, Arizona, a survey of prehistoric sites in the region of (Colton).

Flannery, Regina. Some notes on a few sites in Beaufort County, South Carolina.

Fletcher, Alice C.:

The Hako: A Pawnee ceremony

and La Flesche, Francis. The Omaha tribe

Fletcher, Robert. On prehistoric trephining and cranial amulets.

Florida, The Seminole Indians of (MacCauley) ........

Flute and Snake ceremonies, Tusayan (Fewkes) .......

Fogelson, Raymond D.

Change, persistence, and accommodation in Cherokee medico-magical beliefs.

and Kutsche, Paul. Cherokee economic cooperatives: The Gadugi.

Folk-lore, An inquiry into the animism and, of the Guiana Indians (Roth).

Food-gathering tribes of the Venezuelan Llanos (Kirchhoff).

Foreword by the editors (Fenton and Gulick) ........

Form and ornament in ceramic art (Holmes) ..........

Formulas:

Cherokee sacred, and medicinal prescriptions, The Swimmer manuscript: (Mooney and Olbrechts).

Sacred, of the Cherokees (Mooney)

Förstemann, E, and others. Mexican and Central American antiquities, calendar systems, and history.

Fort Lookout Trading Post II (39LM57) in the Fort Randall Reservoir, South Dakota, The excavation and investigation of (Miller).

Fort Pierre II (39ST217), a historic trading post in the Oahe Dam area, South Dakota (Smith).

\section{A $\quad 16,267$. \\ A 22 (pt. 1), 3 . \\ A 32,37 .}

B 143 , vol. 5, pp. 283292.

B 180, pp. 239-246.

180, pp. 25-38.

133, Anthrop. Pap. No. 20, p. 133.

B 125 .

B 143 , vol. 5 , pp. 277281.

B 104 .

B 133, Anthrop. Pap. No. 21.

A 22 (pt. 2), 5.

A 27, 17 .

C 5 .

A 5,469 .

A 19,957 .

B 180,pp. 213-225.

B 180 ,pp. 83-123.

A 30, 103.

B 143, vol. 4, 445468.

B 180, pp. 3-8.

A 4, 437 .

B 99 .

A 7,301 .

B 28.

B 176, Riv. Bas.

Surv. Pap. No. 17.

B 176, Riv. Bas.

Surv. Pap. No. 18. 
Foster, George M., assisted by Gabriel Ospina. P 6 . Empire's children: The people of Tzintzuntzan.

and Foster, Mary L. Sierra Popoluca speech.... P 8.

Foster, Mary L., and Foster, George M. Sierra Popoluca P 8. speech.

Fowke, Gerard:

Antiquities of central and southeastern Missouri_- B

Archeological investigations.................. $\mathrm{B}$

Archeological investigations-II . . . . . . .

Archeologic investigations in James and Potomac Valleys.

Stone art

Fox ethnology, Contributions to (Michelson)

Fox ethnology-II, Contributions to (Michelson).....

Fox Indian woman, Autobiography of (Michelson)....

Fox Indians:

Ethnography of (Jones) _........................

Mythical origin of the White Buffalo dance of the (Michelson).

Notes on the Buffalo-head dance of the Thunder gens of the (Michelson).

Observations on the Thunder dance of the Bear gens of the (Michelson).

The owl sacred pack of the (Michelson) .........

Fox miscellany (Michelson) _........................

Fox mortuary customs and beliefs, Notes on (Michelson).

Fox society known as "The Singing Around Rite," Traditional origin of the (Michelson).

Fox society known as "Those Who Worship the Little Spotted Buffalo," Notes on the (Michelson).

Fox Wâpanōwiweni, Notes on the (Michelson) .......

Frachtenberg, Leo J. Alsea texts and myths........ See also Bulletin 40 (pt. 2).

Freire-Marreco, Barbara, and others. Ethnobotany of the Tewa Indians.

Frenguelli, Joaquin. The present status of the theories concerning primitive man in South America.

Fulnio, The (Metraux) _........................

Furniture, dwellings, and implements, Omaha (Dorsey).

Furniture, Household (Bennett)

Furuhelm, J. Notes on the natives of Alaska

B 125 .

A 40,23 .

B 87 .

B 89.

B 72 .

B 114.

A 40,351 .

A $40,541$.

A 40,497 .

B 105.

B 67.

B 55 .

B 143, vol. 6, pp. 1117.

B 143, vol. 1, p. 571 .

A 13, 263.

B 143, vol. 5 , pp. $21-$ 27.

C 1,111.

Galvão, Eduardo. See Wagley, Charles, and Galvão, Eduardo.

Gambling, Games and (Cooper)

B 143, vol. 5, pp. 503524.

Games of the North American Indians (Culin)

A 24, 3 .

Gann, Mary. See Gann, Thomas, and Gann, Mary. 
Gann, Thomas:

Maya Indians of southern Yucatan and northern B 64. British Honduras.

Mounds in northern Honduras

and Gann, Mary. Archeological investigations in B

the Corozal District of British Honduras.

See also Cave, A. J. E.

García Valdes, Pedro. The ethnology of the Ciboney.

Gatschet, Albert S.:

Method of recording Indian languages_.........

The Klamath Indians of southwestern Oregon

and Swanton, John R. A dictionary of the Atakapa language.

Ge, The Northwestern and Central (Lowie)

A 19,655 .

B 123, Anthrop. Pap. No. 7.

B 143, vol. 4, pp. 503505.

A 1,579 .

C 2.

B 108 .

B 143, vol. 1, pp. 477517.

Gearing, Fred 0 . The rise of the Cherokee State as an instance in a class: The "Mesopotamian" career to statehood.

Gems and ornamental stones, The mining of, by American Indians (Ball).

General index, annual reports of the Bureau of American Ethnology (Bonnerjea).

Geographical pathology of Chile, The (Herzog)

Geography of South America, The (Sauer)

Geology of the Hodges site, Quay County, New Mexico (Judson).

Geology of the Pickwick Basin in adjacent parts of Tennessee, Mississippi, and Alabama (Jones).

Georgia, Macon, Archeological explorations at (Kelly).

Gesture signs and signals of the North American Indians (Mallery).

Gesture speech, Introduction to the study of sign lan- I guage as illustrating (Mallery).

Ghost-dance religion (Mooney)

\section{Gibbs, George :}

Dictionary of the Niskwalli..................

Tribes of western Washington and northwestern Oregon.

Use of numerals among the T'sim si-an' ......... and Dall, W. H. Vocabularies [of tribes of the extreme Northwest].

Gifford, $\mathbf{E}$. W. The Kamia of Imperial Valley_._._. B 97.

Gila and Salt River Valleys, upper, Antiquities of B $\mathbf{3 5 .}$

(Hough).

Gilbert, William Harlen, Jr. The Eastern Cherokees_- B 133, Anthrop. Pap. No. 23. 


\section{Gillin, John :}

Moche: A Peruvian coastal community

Quichua-speaking Indians of the Province of Imbabura (Ecuador) and their anthropometric relations with the living populations of the Andean area.

Tribes of the Guianas

Gilmore, Melvin R. Uses of plants by Indians of the Missouri River region.

Gilmore, Raymond M. Fauna and ethnozoology of South America.

Goajiro, The (Armstrong and Métraux)

Goddard, P. E. See Bulletin 40 (pt. 1).

Goggin, John M. Comment on John Witthoft's "Eastern Woodlands Community Typology and Acculturation."

Gold and other metals, Use of, among the ancient inhabitants of Chiriqui (Holmes).

Goldfrank, Esther S. (edilor). Isleta paintings, with introduction and commentary by Elsie Clews Parsons. In press.

Goldman, Irving. Tribes of the Uaupés Caquetá region.

Grammar, texts, and ethnography, Dakota (Riggs) ...

Guaymí, and dictionary with some ethnological notes.

Gran Chaco, The present-day Indians of the (Belaieff) -

Grange, Roger T., Jr., and Smith, Carlyle S. The Spain site (39LM301), a winter village in Fort Randall Reservoir, South Dakota.

Graphic system and ancient methods of the Mayas (Brinton).

Greater Pampa, The archeology of the (Willey) ......

Great Salt Lake region, Ancient caves of the (Steward)-

Green Bear who was blessed with a sacred pack (Michelson).

Griffin, James B. An analysis and interpretation of the ceramic remains from two sites near Beaufort, South Carolina.

Guaitacá, The (Métraux)

Guajá, The (Nimuendajú)

Guaporé River, Tribes of the right bank of the (Lévi- B Strauss).

Guaraní, The (Métraux) ...................... B

Guató, The (Métraux)
3.

128, Anthrop. Pap. No. 16.

143, vol. 3, pp. 799860 .

33,43 .

143, vol. 6, pp. 345464.

B 143, vol. 4, pp. 369383.

180, pp. 77-81.

3.

181.

143, vol. 3, pp. 763798 .

9.

162.

143, vol. 1, pp. 371380.

169, Riv. Bas.

Surv. No. 11.

5 (pt. 3), xvII.

143, vol. 1, pp. 2546.

116.

119, Anthrop. Pap. No. 4.

133, Anthrop. Pap. No. 22.

143 , vol. 1 , pp. 521522.

143, vol. 3, pp. 135136.

143, vol. 3 , pp. 371379.

143, vol. 3 , pp. 6994.

143, vol. 1, pp. 409418. 
Guayakí, The (Métraux and Baldus)

Guaymi grammar and dictionary, with some ethnological notes (Alphonse).

Guayupé and Sae, The (Kirchhoff)

Guck, The (Lowie)

Guernsey, Samuel J. See Kidder, A. V.

Guiana Indians:

Additional studies of the arts, crafts, and customs of the, with special reference to those of southern British Guiana (Roth).

Animism and folk-lore of the, An inquiry into the (Roth).

Arts, crafts, and customs of the, An introductory study of the (Roth).

Guianas, Tribes of the (Gillin)

\section{Gulick, John.}

Second comment on Charles H. Holzinger's "Some Observations on the Persistence of Aboriginal Cherokee Personality Traits."

and Fenton, William N. (editors). Symposium on Cherokee and Iroquois culture.

See also Fenton, William N., and Gulick, John, editors.

Gullberg, Jonas E. Technical notes on concave mirrors (appendix 3).

Gunnerson, James H. An introduction to Plains Apache archeology - the Dismal River Aspect.

Haag, William G. A description and analysis of the B Pickwick pottery.

Haas, Mary R. Comment on Floyd G. Lounsbury's B "Iroquois-Cherokee Linguistic Relations."

Habitations (Bennett)

Habitations. See Dwellings; Houses.

Haeberlin, H. K.; Teit, James A.; and Roberts, Helen

H. (under direction of Franz Boas). Coiled basketry in British Columbia and surrounding region.

Haida language. See Bulletin 40 (pt. 1).

Haida texts and myths (Swanton) ............. B

Hair of South American Indians, The pigmentation and $B$ (Steggerda).

Hair pipes in Plains Indian adornment, a study in In- B dian and White ingenuity (Ewers).

Hako, The: A Pawnee ceremony (A. C. Fletcher) .....

Halbert, Henry S. (editor). A dictionary of the Choc- B taw language.

Hale, Edward Everett. Introduction to Natick dic- B tionary (Trumbull).

Handbook of aboriginal American antiquities. Pt. 1- B Introductory: The lithic industries (Holmes).
143, vol. 1, pp. 435444.

162.

143, vol. 4, pp. 385391.

143, vol. 1, p. 569.

B 91.

A $\quad 30,103$.

A $38,25$.

B 143, vol. 3, pp. 799860.

180, pp. 247-252.

180.

170, 280-283.

173, Anthrop. Pap. No. 58 .

129, pp. 509-526.

180, pp. 19-23.

143, vol. 5, pp. 120.

$41,119$.

29.

143, vol. 6, pp. 8590 .

164, Anthrop. Pap.

No. 50.

22 (pt. 2), 5.

46.

25.

60. 
Handbook of American Indian languages (Boas, editor)_- B 40.

Handbook of American Indians north of Mexico (Hodge, B 30. editor).

Handbook of South American Indians (Steward, editor)__ B 143.

Handbook of the Indians of California (Kroeber) _._. B 78 .

Harrington, J. P.:

Ethnogeography of the Tewa Indians__._._._. $\Lambda$ 29, 29.

Exploration of the Burton Mound at Santa Bar- $A \quad 44,23$. bara, California.

Kiaruk Indian myths........................ B 107.

The original Strachey vocabulary of the Virginia B 157, Anthrop. Pap. Indian language.

Tobacco among the Karuk Indians of California -- B

Valladolid Maya enumeration................ B

Vocabulary of the Kiowa language

and Henderson, Junius. Ethnozoology of the $B$ Tewa Indians.

and Roberts, Helen H. Picuris children's stories, A with texts and songs.

and others. Ethnobotany of the Tewa Indians_.. B

Hartle, Donald D. The dance hall of the Santee Bot- B toms on the Fort Berthold Reservation, Garrison Reservoir, North Dakota. In press.

Hasjelti Dailjis ceremonial of the Navajo (J. Steven- A 8, 229. son).

Hawaii:

Archeological work in (Fowke) _............ B

Unwritten literature of (Emerson) _........... B

Hawaiian romance of Laieikawai (Beckwith) _....... A

Heizer, Robert F.:

Aboriginal fish poisons . .

Aconite poison whaling in Asia and America: An B Aleutian transfer to the New World.

Fish poisons.

and Drucker, Phillip, and Squier, Robert J. Ex- B cavations at La Venta, Tabasco, 1955. With appendixes by Jonas E. Gullberg, Garniss $\mathbf{H}$. Curtis, and A. Starker Leopold.

and Massey, William C. Aboriginal navigation off the coasts of Upper and Baja California.

\section{Henckel, Carlos:}

The anthropometry of the Indians of Chile.....

The physical anthropology of the internal organs among the races of Chile.

Henderson, Junius, and Harrington, J. P.:

Ethnozoology of the Tewa Indians_ 76.

B 38.

A $33,285$.

B 151, Anthrop. Pap.

No. 38.

133, Anthrop. Pap.

No. 24.

143 , vol. 5, pp. 277281.

170.

The physiography of the Rio Grande

Valley, New Mexico.

B 143, vol. 6, pp. 121135.

B 143, vol. 6, pp. 145156.

B 56.

B 54. 
Henshaw, H. W.:

Animal carvings from mounds of the Mississippi A 2, 117. Valley.

Perforated stones from California_._._._._... B 2.

Tribes of North America, with synonymy. Skit- M 5 . tagetan family.

Hernández de Alba, Gregorio:

Achagua and their neighbors, The.

B 143, vol. 4, pp. 399412.

Archeology of San Agustín and Tierradentro, Co- B lombia, The.

Betoi and their neighbors, The

143, vol. 2, pp. 851859.

Highland tribes of southern Colombia, The _.....

Sub-Andean tribes of the Cauca Valley

B 143, vol 4, pp. 393398.

B 143, vol. 2, pp. 915961.

Tribes of north central Venezuela, The _....... I3

143, vol. 4, pp. 297327.

143, vol. 4, pp. 475479 .

Tribes of the North Colombia Lowlands ........ B

143, vol. 4, pp. 329 338.

Tribes of northwestern Venezuela, The

$\mathrm{B}$

143, vol. 4, pp. 469474.

Herzog, Ernesto. The geographical pathology of Chile_

\section{Hewett, Edgar Lee:}

Antiquities of the Jemez Plateau, New Mexico... and others. The physiography of the Rio Grande Valley, New Mexico.

Hewitt, J. N. B.:

Comparative lexicology [of the Serian and Yuman languages].

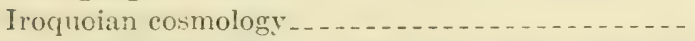

Iroquoian cosmology: second part, with introduction and notes.

Notes on Creek Indians

and Curtin, Jeremiah. Seneca fiction, legends, and myths.

See also Denig, Edwin T.; Kurz, Rudolph Friederich Hidatsa music, Mandan and (Densmore)

B 143, vol. 6, pp. 137144.

B 32.

B 54.

A 17, pt. 1, 299*.

A $21,127$.

A 43, 449 .

B 123, Anthrop. Pap. No. 10.

A 32, 37.

Hieroglyphs, Maya, An introduction to the study of the (Morley).

Highland communities of central Peru (Tschopik) -.---

Highland tribes of southern Colombia, The (Hernández de Alba).

Hilger, Sister M. Inez:

Arapaho child life and its cultural background...-

Chippewa child life and its cultural background.Hispaniola, The ethnography of (Ciguayo) ........... Hispaniola, The ethnography of (Taino)

B 80.

B 57.

P 5.

B 143, vol. 2, pp. 915961.

B 148 .

B 146 .

B 143, vol. 4, pp. 539.

B 143, vol. 4, pp. 522539. 
Historical and ethnographical material on the Jivaro B 117. Indians (Stirling).

Historic sites archeology in the Fort Randall Reserva- B 176, Riv. Bas. tion, South Dakota (Mills).

Historic sites archeology on the upper Missouri (Mattes).

Historic sites in and around the Jim Woodruff Reservoir Area, Florida-Georgia (Boyd).

History, Early, of the Creek Indians and their neighbors (Swanton).

History and ethnology of the Caddo Indians, Source material on the (Swanton).

Hodge, F. W.:

Advance pages. Dictionary of American Indians north of Mexico.

List of publications of the Bureau of Ethnology -editor. Handbook of American Indians north of B Mexico.

Hodges site, The:

I. Two rock shelters near Tucumcari, New B 154,267-284. Mexico (Dick).

II. Geology of the Hodges site, Quay County, B 154, 285-302.

\section{Hoffman, Walter James:} New Mexico (Judson).

The Menomini Indians.

A 14,3 .

The Mide'-wiwin or "Grand Medicine Society" of A 7, 143. the Ojibwa.

Holden, E. S. Studies in Central American picture- A 1, 205. writing.

Holland, C. G.:

An analysis of projectile points and large blades.-

Preceramic and ceramic cultural patterns in northwest Virginia.

Holmberg, Allan R.:

Nomads of the long bow: The Siriono of eastern $P \quad 10$. Boliva.

The Siriono

\section{Holmes, William H.:}

Aboriginal pottery of the eastern United States..-

An ancient quarry in Indian Territory ..........

Ancient art of the province of Chiriqui, Colombia -

Ancient pottery of the Mississippi Valley .......

Art in shell of the ancient Americans..........

A study of the textile art in its relation to the development of form and ornament.

Ilandbook of aboriginal American antiquities, Pt. 1-Introductory: The lithic industries.

B 143 , vol. 3, pp. $454-$ 463.

B 160,165 .

B 173, Anthrop. Pap. No. 57.

A 20,1 .

B 21.

A 6,3 .

A 4,361 .

A 2,179 .

A 6,189 .

B 60 . 
Holmes, William H.-Continued

Illustrated catalogue of a portion of the collections made by the Bureau of Ethnology during field season of 1881 .

Introduction "Archeologic investigations in James and Potomac Valleys" (Fowke).

Origin and development of form and ornament in ceramic art.

Pottery of the ancient Pueblos

Prehistoric textile art of eastern United States....

Prehistoric textile fabrics of the United States, derived from impressions on pottery.

Stone implements of the Potomac-Chesapeake tidewater province.

Textile fabrics of ancient Peru...................

The use of gold and other metals among the ancient inhabitants of Chiriqui, Isthmus of Darien.

(collaborator.) Early man in South America.....

Holzinger, Charles $\mathbf{H}$. Some observations on the persistence of aboriginal Cherokee personality traits.

Honduras:

and Nicaragua, Ethnographical survey of the Miskito and Sumu Indians of (Conzemius). northern, Mounds in (Gann)

The archeology of (Strong)

See also British Honduras.

Hopi katcinas, drawn by native artists (Fewkes)....... Hopi pottery, prehistoric, Designs on (Fewkes)

See also Tusayan.

Horse in Blackfoot Indian culture, The, with comparative material from other western tribes (Ewers).

Horton, Donald. The Mundurucú

Hostos, Adolfo de. The ethnography of Puerto Rico_

Hou, Ding. See Nickerson, Norton H.

Hough, Walter. Antiquities of the upper Gila and Salt River Valleys.

House mounds, Aboriginal (Fowke)

Houses:

and house-life of the American aborigines (Morgan).

and house use of the Sierra Tarascans (Beals, Carrasco, and McCorkle).

Navaho (C. Mindeleff)

See also Dwellings.

House types, archeological remains in eastern Arizona B (Robert8).

Howard, James H. Dakota winter counts as a source B of Plains history.
A 3, 427 .

B 23 .

A 437.

A 4,257 .

A 13,3 .

A 3,393 .

A 15,3 .

B 7.

B 3 .

B 52.

B 180,pp. 227-237.

B 106 .

A 19,655 .

B 143, vol. 4, pp. 71120.

A 21, 3.

A $\mathbf{3 3}, 208$.

B 159 .

B 143, vol. 3, pp. 271282.

B 143, vol. 4, pp. 540542 .

B 35 .

B 76.

4.

1.

A $\quad 17,469$.

121.

173, Anthrop. Pap. No. 61. 
Hoyme, Lucile E., and Bass, William M. Human skeletal material from site 44Mc14, Mecklenburg County, and site $44 \mathrm{Ha} 6$, Halifax County, Virginia (appendix). In press.

\section{Hrdlička, Aleš :}

Anthropological survey in Alaska

Physical anthropology of the Lenape or Delawares, and of the eastern Indians in general.

Physiological and medical observations among the Indians of southwestern United States and northern Mexico.

Recent discoveries [of remains] attributed to early man in America.

Skeletal material from Missouri................

Skeletal remains suggesting or attributed to early B man in North America.

Tuberculosis among certain Indian tribes of the B United States.

in collaboration with Holmes, Willis, Wright, and B

Fenner. Early man in South America.

II uarpe, The (Canals Frau)

Hudson Bay Territory, Enthnology of the Ungava district (Turner).

Hula, Sacred songs of the (Emerson) _.......... B

Human skeletal material from site $44 \mathrm{Mc} 14$, Mecklenburg County, and site $44 \mathrm{Ha} 6$, Halifax County, Virginia (appendix) (Hoyme and Bass). In press.

Human trophies, Warfare, cannibalism, and (Métraux)_

Hunt, George. See Boas, Franz. Ethnology of the Kwakiutl Indians.

Hupa language. See Bulletin 40 (pt. 1).

Illustrated catalogue:

of collections from New Mexico and Arizona in 1879 (J. Stevenson).

of collections from New Mexico in 1880 (J. Stevenson).

of collections from pueblos in 1881 (J. Stevenson) of collections made in 1881 (Holmes)

Illustration of the method of recording Indian languages (Dorsey, Gatschet, and Riggs).

Imbelloni, José. Cephalic deformations of the Indians in Argentina.

Imperial Valley, The Kamia of (Gifford) _.......... B

Implements:

Omaha dwellings, furniture and (Dorsey)

Stone, of the Potomac-Chesapeake tidewater province (Holmes).

Inca culture at the time of the Spanish Conquest B (Rowe).
182, Riv. Bas. Surv. Pap.

No. 25.

A 46,19 .

62.

34.

66.

37, 103-112.

33.

42.

52.

B 143, vol. 1, pp. 169175.

11, 159 .

38.

182, Riv. Bas.

Surv. Pap.

No. 25.

143, vol. 5, pp. 383409.

$35,43$.

A $2,307$.

2,423 .

3, 511 .

3,427 .

1,579 .

143, vol. 6, pp. 5355.

97.

A 13, 263.

A $\quad 15,3$.

143, vol. 2, pp. 183330. 
Index, General, annual reports of the Bureau of American Ethnology (Vols. 1-48) (Bonnerjea).

Index to Bulletins 1-100 of the Bureau of American Ethnology (Bonnerjea). In press.

Index to Schoolcraft's "Indian tribes of the United States," compiled by Frances S. Nichols.

Indian caste of Peru, 1795-1940: A population study based upon tax records and census reports (Kubler).

Indian copper beads found at the McNary Dam, Oregon, Report on the composition of (appendix 3).

Indian markets and fairs in Perú (Valcárcel)

Indian missions (Mooney)

Indians, South American, Anthropometry of (Steggerda).

Indians, South American, Blood groups of (Boyd) ...-

Indians, South American, The basal metabolic rates of (Wilson).

Indians, South American, The languages of (Mason) --

Indians, South American, The pigmentation and hair of (Steggerda).

Indians of Brazil, The anthropometry of the (Bastos d'Avila).

Indians of Chile, The anthropomentry of the (Henckel).

Indians of the Southeastern United States, The (Swanton)

Indian skeletal remains, South American, Anthropometry of (Stewart and Newman).

Indian skeletal remains, South American, Deformity, trephining, and mutilation in (Stewart).

Indian skeletal remains, South American, Pathological changes in (Stewart).

Indian skeletal remains from the Doering and Kobs sites, Addicks Reservoir, Texas (Newman).

Indian Territory, Ancient quarry in (Holmes_.......

Indian trails of the Southeast (Myer) .............

Indian tribes of North America, The (Swanton) .......

Indian tribes of northern Mato Grosso, Brazil, by Kalervo Oberg, with an appendix entitled "Anthropometry of the Umotina, Nambicuara, and Iranxe, with comparative data from other northern Mato Grosso tribes," by Marshall T. Newman.

Industries; Technology, or the science of (Powell) ..... Inhabitants of the North Chilean Coast, The historic (Bird).

Initiation rites, Boys' (Métraux) ....................

Innuit, Terms of relationship used by the (Dall) Institutions; Sociology, or the science of (Powell) .....-
A 48,25 .

178.

152.

14.

166.

B 153, vol. 2, pp. 477482.

M 9.

B 143, vol. 6, pp. 5769.

B 143, vol. 6, pp. 9195.

143, vol. 6, pp. $97-$ 104.

143, vol. 6 , pp. 157 317.

143 , vol. $6, \mathrm{pp} .85-$ 90.

143, vol. 6, pp. 7184.

143, vol. 6, pp. 121135.

137.

143, vol. 6, pp. 1942.

143 , vol. 6 , pp. $43-$ 48.

143, vol. 6, pp. 4952.

B 154, Riv. Bas. Surv. Pap. No. 4, Pt. 2.

21.

42,727 .

145.

15.

A 20, xxIx.

B 143, vol. 2, pp. 595597.

B 143, vol. 5, pp. 375 382.

C 1, 117 .

A 20, LIX. 
Instruction; Sophiology, or the science of activities de- A signed to give (Powell).

Internal organs among the races of Chile, The physical B anthropology of (Henckel).

Introduction:

to Natick dictionary (Hale)

to Pawnee archeology (Wedel)

to the study of Indian languages (Powell)

to the study of mortuary customs (Yarrow)

to the study of sign language (Mallery)

to Zuñi ceremonialism (Bunzel)

Iroquoian cosmology (Hewitt)

Iroquoian cosmology: second part, with introduction and notes (Hewitt).

Iroquoian culture history: A general evaluation (Fenton).

Iroquoian languages, Bibliography of the (Pilling) ....

Iroquois, Myths of the (Smith)

Iroquois archeology and settlement patterns (Ritchie).

Iroquois-Cherokee linguistic relations (Lounsbury) -...-

Iroquois Eagle Dance, an ofishoot of the Calumet Dance (Fenton), with an analysis of the Iroquois Eagle Dance and songs (Kurath).

Iroquois fortunetellers, The, and their conservative influence. (Shimony).

Iroquois suicide: A study in the stability of a culture pattern (Fenton).

Iroquois women, then and now (Randle)

Island culture area of America, A prehistoric (Fewkes).

Isleta, New Mexico (Parsons)

Isleta paintings, with introduction and commentary by Elsie Clews Parsons. Esther S. Goldfrank, editor. In press.

Ives, Ronald L. (translator and editor). Sedelmayr's Relación of 1746.

Jaguar in Mexico, The range of the (Leopold) (appendix $5)$.

James and Potomac Valleys, Archeologic investigations in (Fowke).

Jarrell, Myrtis. See Kurz, Rudolph Friederich.

Jeancon, J. A. Excavations in the Chama Valley, New Mexico.

Jeico, The (Lowie)

Jelks, Edward B. Excavations at the Texarkana Reservoir, Sulphur River, Texas.

Jemez Plateau, New Mexico, Antiquities of the B (Hewitt).

Jenks, Albert Ernest. Wild rice gatherers of the upper lakes.

Jenness, Diamond. The Carrier Indians of the Bulkley River: Their social and religious life.
20, CLXXI.

143, vol. 6, pp. 145156.

25.

112.

1 and 2.

4.

3.

$47,467$.

$21,127$.

43, 499 .

180, pp. 253-257.

6.

2,47 .

180, pp. 25-38.

180, pp. 9-17.

156.

180, pp. 205-211.

B

128, Anthrop. Pap.

No. 14.

B 149, 167-180.

A 34,35 .

A $47,193$.

B 181.

B 123, Anthrop. Pap. No. 9.

B 170 .

B 23.

B 81 .

B 143, vol. 1, p. 567.

B 179, Riv. Bas.

Surv. Pap. No.

21.

32.

A $\quad 19,1013$.

B 133, Anthrop. Pap.

No. 25. 
Jennings, Jesse D.; Willey, Gordon R.; and Newman, Marshall T. The Ormond Beach Mound, East Central Florida.

and Setzler, Frank M. Peachtree Mound and village site, Cherokee County, North Carolina.

Jesuit missions in South America (Métraux)

Jibaro Indians of eastern Ecuador, Blood revenge, war and victory feasts among the (Karsten).

Jicaque, The Mosquito, Sumo, Paya, and, The Caribbean Lowland tribes: (Kirchhoff).

Jim Woodruff Reservoir area, Florida, Six sites near the Chattahoochee River in the (Bullen).

Jivaro Indians, Historical and ethnographical material (Stirling).

Johnson, Frederick:

Central American cultures

The Caribbean Lowland tribes: The Talamanca Division.

The Meso-American Division

The post-Conquest ethnology of Central America -

See also Strong, William Duncan, and Johnson, Frederick.

Jones, J. A. The Sun Dance of the Northern Ute.....

Jones, Walter B. Geology of the Pickwick Basin in adjacent parts of Tennessee, Mississippi, and Alabama.

Jones, William. Ethnography of the Fox Indians....

Jones, William. See Bulletin 40 (pt. 1).

Journal of an expedition to the Mauvaises Terres and the Upper Missouri in 1850, by Thaddeus A. Culbertson (edited by John Francis McDermott).

Journal of Rudolph Friederich Kurz (Kurz)

Judd, Neil M. Archeological observations north of the Rio Colorado.

Judson, Sheldon. Geology of the Hodges site, Quay County, New Mexico.

Juruá-Purús Basins, Tribes of the (Métraux) .........

Kamia, The, of Imperial Valley (Gifford)

Karsten, Rafael. Blood revenge, war, and victory feasts B among the Jibaro Indians of eastern Ecuador.

Karuk Indian myths (Harrington) ............... B

Karuk Indians of California, Tobacco among the (Har- B rington).

Katcinas:

Hopi, drawn by native artists (Fewkes) ......... A

Tusayan (Fewkes) ........................ A

Zuñi (Bunzel)
B 164, Anthrop. Pap. No. 49.

B 131 .

B 143, vol. 5, pp. 645653.

79.

B 143, vol. 4, pp. 219229.

B 169, Riv. Bas. Surv. Pap. No. 14.

B 117.

B 143, vol, 4, pp. 4368.

B 143, vol. 4, pp. 231251.

143, vol. 4, pp. 199204.

B 143, vol.4, pp. 195198.

B 157, Anthrop. Pap. No. 47.

129, pp. 327-335.

125.

147.

B 115 .

B 82 .

B 154, Riv. Bas.

Surv. Pap. No. 5, Pt. 2.

B 143, vol. 3, pp. 657686.

97.

79.

107.

94.

21, 3.

15, 245.

47, 837. 
Kathlamet texts (Boas)

Kehoe, Thomas F. Stone tipi rings in north-central Montana and the adjacent portion of Alberta, Canada: Their historical, ethnological, and archeological aspects.

Kelley, A. R. A preliminary report on archeological explorations at Macon, Ga.

Kelly, Isabel, and Palerm, Angel. The Tajin Totonac: Part 1. History, subsistence, shelter, and technology. Kiatuthlanna, eastern Arizona, The ruins at (Roberts)..

Kidder, Alfred II. The archeology of Venezuela........

Kidder, Alfred Vincent, and Guernsey, Samuel J. Archeological explorations in northeastern Arizona.

Kiowa Indians, Calendar history of the (Mooney) ....-

Kiowa language, Vocabulary of the (Harrington) .....

Kipp's Post (32MN1) in the Garrison Reservoir, North Dakota, The archeology of a small trading post (Woolworth and Wood).

\section{Kirchhoff, Paul:}

Food-gathering tribes of the Venezuelan Llanos....

The Caribbean Lowland tribes: The Mosquito, Sumo, Paya, and Jicaque.

The Guayupé and Sae

The Otomac

The Patángoro and Amaní

The social and political organization of the Andean peoples.

The tribes north of the Orinoco River

The Warrau

See also Métraux, Alfred, and Kirchhoff, Paul.

Kivett, Marvin F. The Woodruff ossuary, a prehistoric burial site in Phillips County, Kansas.

Klamath Indians of southwestern Oregon, The (Gatschet).

Kroeber, A. L.:

Art

Handbook of the Indians of California

The Chibcha.

Kroll, W. J. Report on the composition of Indian copper beads found at the MeNary Dam, Oregon (appendix 3).
B 26.

B 173, Anthrop. Pap.

No. 62.

B 119, Anthrop. Pap. No. 1.

13.

100.

B 143, vol. 4, pp. 413438.

65.

A $\quad 17,129$.

B 84 .

B 176, Riv. Bas.

Surv. Pap. No. 20.

B 143, vol. 4 , p p. 445468.

B 143, vol. 4, pp. $219-$ 229.

B 143 , vol. 4, pp. 385391.

B 143, vol. 4, pp. 439444.

B 143,vol. 4, pp. 339348.

B 143, vol. 5, pp. 293311.

B 143, vol. 4, pp. 481493.

B $\quad 143$, vol. 3 , pp. 869 881.

B 154, Riv. Bas. Surv. Pap. No. 3.

2.

B 143, vol. 5, pp. 411492.

78.

143, vol. 2 , pp. 887 909.

B 166. 


\section{Kubler, George :}

Indian caste of Peru, 1795-1940, The: A popula- P

14. tion study based upon tax records and census reports.

Quechua in the Colonial world, The

B 143, vol. 2, pp. 331410.

\section{Kurath, Gertrude Prokosch.}

An analysis of the Iroquois Eagle Dance.

B 156, 223.

Effects of environment on Cherokee-Iroquois cere- I monialism, music, and dance.

See also Fenton, William N., editor.

Kurz, Rudolph Friederich. Journal of Rudolph Friede- B 115.

rich Kurz. Translated by Myrtis Jarrell, edited by J. N. B. Hewitt.

Kutsche, Paul, and Fogelson, Raymond D. Cherokee B 180, pp. 83-123. economic cooperatives: The Gadugi.

Kutenai tales (Boas and Chamberlain) _........... B 59.

Kwakiutl Indians, Ethnology of the (Boas) _........... A 35, 43.

Kwakiutl language. See Bulletin 40 (pt. 1).

La Barre, Weston. The Uru-Chipaya

B 143, vol. 2, pp. 575585 .

Labrets, masks, and certain aboriginal customs (Dall) La Candelaria, The culture of (Willey) ..............

\section{La Flesche, Francis:}

A dictionary of the Osage language .............

The Osage tribe: Rite of the chiefs; sayings of the ancient men.

The Osage tribe: Rite of the Wa-xo'-be

The Osage tribe: The rite of vigil_._._..........

The Osage tribe: Two versions of the child-naming rite.

War cermony and peace ceremony of the Osage Indians.

and Fletcher, Alice C. The Omaha Tribe......

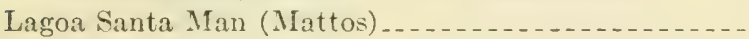

Laguna, Frederica de. The story of a Tlingit community: A problem in the relationship between archeological, ethnological, and historical methods.

Land cessions, Indian, in the United States (Royce and Thomas).

Landy, David. First comment on Charles H. Holzinger's "Some Observations on the Persistence of Aboriginal Cherokee Personality Traits."

\section{Language:}

Evolution of (Powell) _......................

Philology, or the science of (Powell)

3,67 .

B 143 , vol. 2 , pp. $661-$ 672.

B 109 .

A 36,37 .

$\Lambda \quad 45,523$.

A 39, 31 .

A 43, 23.

B 101 .

A 27,17 .

B 143, vol. 1, pp. 399400.

B 172 .

18 (pt. 2), 521.

B 180, pp. 239-246.

The Cegiha (Dorsey)

A $1,1$.

A 20, cxxxix.

() 6 . 
Languages:

Handbook of Indian (Boas, editor)

Indian, of Mexico and Central America (Thomas and Swanton).

Introduction to the study of Indian (Powell) .....-

Method of recording Indian (Dorsey, Gatsehet, and Riggs).

Of South American Indians, The (Mason)

Of southwestern Colombia, The native tribes and (Ortíz).

of the North American Indians, Proof-sheets of a bibliography of the (Pilling).

Structural and lexical comparison of the Tunica, Chitimacha, and Atakapa (Swanton).

See also Bibliography; Dictionary; Grammar; Texts; Vocabulary.

La Plata Littoral, Indians of the Paraná Delta and (Lothrop).

Larco Hoyle, Rafael. A culture sequence for the North Coast of Perú.

La Venta, Tabasco: A study of Olmec ceramics and art (Drucker). With a chapter on structural investigations in 1943 (Wedel), and appendix on technological analyses (Shepard).

Legends, and myths, Seneca fiction (Hewitt) .........

Lehmann, Henri :

The archeology of the Popayán region, Colombia_-

The Moguex-Coconuco

Lehmer, Donald J. Archeological investigations in the Oahe Dam area, South Dakota, 1950-51.

Lemhi Shoshoni physical therapy (Steward) ...........

Lenape, or Delawares, Physical anthropology of the (Hrdlička).

Lenca, The. The Northern Highland tribes: (Stone) -

Leopold, A. Starker. The range of the jaguar in Mexico (appendix 5).

Letters, Omaha and Ponka (Dorsey) _.............

Letters to Jack Wilson, the Paiute Prophet, written between 1908 and 1911, edited and with an introduction by Grace M. Dangberg.

\section{Lévi-Strauss, Claude:}

The Nambicuara ........................

The Tupi-Cawahib

The use of wild plants in tropical South America

B

$\mathrm{B}$

B 153.

A 32,37 .

B 143, vol. 2, pp. 861864.

B 143, vol.2, pp. 969974.

B 158, Riv. Bas. Surv. Pap. No. 7.

B 119, Anthrop. Pap. No. 5.

B 62 .

B 143, vol. 4, pp. 205217.

B 170 .

B 11 .

B 164, Anthrop. Pap. No. 55 .

143, vol. 3 , pp. 361369.

B 143, vol. 3, pp. 299305.

B 143, vol. 6, pp. 465486. 
Lévi-Strauss, Claude-Continued

Tribes of the right bank of the Guaporé River... I3 143, vol. 3, pp.371-

Tribes of the upper Xingú River 379.

143, vol. 3 , pp. 321348.

Lexicology, Comparative [of the Serian and Yuman languages] (Hewitt).

Limitations to the use of some anthropologic data $\Lambda \quad 1,71$. (Powell).

Linguistic classification of Algonquian tribes, Prelim- A inary report on the (Michelson).

Linguistic classification of Cree and Montagnais-Naskapi dialects (Michelson).

Iinguistic families:

of America north of Mexico, Indian (Powell) ......

of the Indian tribes north of Mexico (Mooney) _-_ M

See also Bulletin 44.

Linguistic manuscripts in the library of the Bureau of A 1,553 . Ethnology, Catalogue of (Pilling).

Linguistic material from the tribes of southern Texas B 127 . and northeastern Mexico (Swanton).

Linguistic stocks north of Mexico, Map of (Powell) _.- M 4, 7.

Lipkind, William. The Carajá_.................. B 143, vol.3, pp. 179191.

List of publications of the Bureau of American Eth- B nology.4

Literature of Hawaii, Unwritten (Emerson)

A $17,20,28,30$;

M $1944,1949,1956$.

Local diversity in Iroquois music and dance (Kurath) - B

Locality as a basic factor in the development of Iroquois B social structure (Fenton).

\section{Lothrop, Samuel K.:}

Indians of the Paraná Delta and La Plata Littoral_ B

The archeology of Panamá 38.

$149,109-137$.

$149,35-54$.

The Diaguita of Chile B

143, vol. 1, pp. 177190.

143, vol. 4, pp. 143167.

143, vol. 2, pp. 633636.

The tribes west and south of the Panamá Canal_- B 143, vol. 4, pp. 253256.

Louisiana:

Choctaw of Bayou Lacomb (Bushnell)

B 48 .

Search for songs among the Chitimacha Indians in, B (Densmore).

The Troyville mounds, Catahoula Parish (Walker).

Lounsbury, Floyd G. Iroquois-Cherokee linguistic B relations.

133, Anthrop. Pap. No. 19.

B 113.

B 180, pp. 9-17.

\footnotetext{
1 Since 1915, the List of Publications of the Bureau of Amerlean Ethnoloyy has been issued as a Miscellaneous publleation.
} 
Lowie, Robert H.:

Eastern Brazil: An introduction

Property among the Tropical Forest and Marginal tribes (Lowic).

Social and political organization of the Tropical B Forest and Marginal tribes.

The Bororo

The Cariri

The Guck

The Jeico

The Northwestern and Central Ge.

The Pancararú

The Southern Cayapó

The Tarairiu

The Tropical Forests: An introduction

MacCauley, Clay. The Seminole Indians of Florida Madeira headwaters, Tribes of eastern Bolivia and the (Métraux).

Maidu language. See Bulletin 40 (pt. 1).

Maine, Wawenock myth texts from (Speck)

Maize from the Phillips Ranch sites (Nickerson and Hou).

Malalí linguistic families. See Mashacali, Patasho, and

Malalí linguistic families (Métraux and Nimuendajú). Mallery, Garrick:

A collection of gesture-signs and signals of the North American Indians, with some comparisons.

Introduction to the study of sign language among North American Indians as illustrating gesture speech of mankind.

Pictographs of the North American Indians; a preliminary paper.

Picture-writing of the American Indians

Sign language among North American Indians compared with that among other peoples and deafmutes.

Malouf, Carling. Crow-Flies-High (32MZ1), a historic Hidatsa village in the Garrison Reservoir Area, North Dakota. In press.

Man, early:

in North America, Skeletal remains of (Hrdlička). in South America (Hrdlička and others) ..........

Man, Primitive, in Argentina. The present status of the theories concerning (Frenguelli).

Mandan and Hidatsa music (Densmore)
B 143 , vol. 1, pp. 381397.

B 143, vol. 5, pp. 351367.

143, vol. 5, pp. 313350.

B 143 , vol. 1, pp. 419434.

B 143, vol. 1, pp. 557559.

B 143, vol. 1, p. 569.

B 143, vol. 1, p. 567 .

B 143 , vol. 1, pp. $477-$ 517.

B 143, vol. 1, p. 561 .

B 143 , vol. 1 , pp. 519520.

B 143 , vol. 1, pp. 563566.

B 143, vol. 3 , pp. 156.

A $\quad 5,469$.

B 143, vol. 3, pp. 381454.

\section{A 43,165 . \\ B 158,180 .}

M 1.

3.

A 4,3 .

A 10,3 .

A 1,263 .

B 185, Riv. Bas. Surv. Pap. No. 29.

B $\mathbf{3 3}, 66$ 。

B 52 .

B 143, vol. 6, pp. 1117.

B 80 . 
Manuscripts:

Linguistic, in the library of the Bureau of Ethnol- A 1,553. ogy, Catalogue of (Pilling).

Notes on certain Maya and Mexican (Thomas) _..Manuscript Troano, A study of the (Thomas) Map of linguistic stocks north of Mexico (Powell) _... Marginal tribes, Tropical Forest and, Property among the (Lowie).

Marginal tribes, Tropical Forest and, Social and politi- $B$ cal organization of the (Lowie).

Markets and fairs in Perú, Indian (Valcárcel)

A 3,3 .

C 5 .

M 4 and 7.

B 143, vol. 5, pp. 351367.

143, vol. 5, pp. 313350.

B 143, vol. 2, pp. 477482.

\section{Márquez Miranda, Fernando:}

The Chaco-Santiagueño culture

B 143, vol. 2, pp. 655660 .

The Diaguita of Argentina

B 143, vol. 2, pp. 637654.

Mashacali, Patashó, and Malalí linguistic families, The (Métraux and Nimuendajú).

Masks, labrets, and certain aboriginal customs (Dall)

Mason, J. Alden. The languages of South American Indians.

Massachusetts. See Natick.

Massey, William C., and Heizer, Robert F. Aboriginal navigation of the coasts of Upper and Baja California.

Mattes, Merrill J. Historic sites archeology on the Upper Missouri.

Matthews, Washington:

Navajo silversmitlıs..........................

Navajo weavers

The mountain chant: A Navajo ceremony .......

Matto Grosso, western, native tribes of (Métraux) ....

Mattos, Anibal. Lagoa Santa Man................

Maue and Arapium, The (Nimuendajú)

143, vol. 1, pp. 541545 .

3,67 .

B 143, vol. 6, pp. 157317.

B 151, Anthrop. Pap. No. 39.

B 176, Riv. Bas. Surv. Pap. No. 15.

A 2,167 .

A 3,371 .

A 5,379 .

B 134 .

B 143, vol. 1, pp. 399400.

B 143 , vol. 3, pp. 245254.

Maya and Mexican manuscripts, Notes on certain A 3,3. (Thomas).

Maya codices, Aids to the study of the (Thomas) -..--

Maya hieroglyphs, An introduction to the study of (Morley).

Maya Indians, The, of southern Yucatan and northern British Honduras (Gann).

Mayan antiquities, calendar systems, and history. See Bulletin 28.

Mayan calendar systems (Thomas)

A 19,693 , and 22 (pt.

1), 197.

Mayas, Graphic system and ancient methods of the (Brinton).

See also Maya Indians.

Maya year, Day symbols of the (Thomas) _........

Maya year, The (Thomas)

A $\quad \mathbf{1 6}, 199$.

B 18 .

$615214-62-7$ 
McBryde, Felix Webster. Cultural and historical $P$ geography of southwest Guatemala.

McCorkle, Thomas; Beals, Ralph L.; and Carrasco, P 1.

Pedro. Houses and house use of the Sierra Tarascans.

McCown, Theodore D. The antiquity of man in South America.

McDermott, John Francis, editor. Journal of an expedition to the Mauvaises Terres and the Upper Missouri in 1850 (Culbertson).

\section{McGee, W. J.}

Preface to The Pamunkey Indians of Virginia (Pollard).

Prefatory note to the Maya year (Thomas)

Primitive numbers... . . . . .

The Seri Indians

The Siouan Indians

B 143, vol. 6, pp. 1-9.

and Muniz, Manuel Antonio. Primitive trephining in Peru.

McLeod, B. H. Examination of copper artifacts from the McNary site, Oregon (appendix 4).

McNary Reservoir, The: A study in Plateau archeology (Shiner).

Measures, weights, and calendars, Numbers (Bennett) -

Medical observations among southwestern Indians B (Hrdlička).

Medical practices (Ackerknecht)

B 147.

Medical practices of the Creek Indians, Religious beliefs and (Swanton).

Medicinal prescriptions, The Swimmer manuscript: Cherokee sacred formulas and (Mooney and Olbrechts).

Medicine bundles of the Florida Seminole and the Green Corn Dance, The (Capron).

Medicine-men of the Apache, The (Bourke)

Meggers, Betty J. The archeology of the Amazon B Basin.

and Evans, Clifford.

Archeological investigations at the mouth of $B$ the Amazon.

Archeological investigations in British Gui- B ana, South America.

Menominee music (Densmore)

B 17.

B 18.

A 19,821 .

A 17,1 .

A 15,153 .

A 16,3 .

B 166 .

B

179, Riv. Bas. Surv. Pap. No. 23.

143, vol. 5, pp. 601610.

34.

143 , vol. 5, pp. 621643.

A $\quad 42,473$.

B 99.

B

151, Anthrop. Pap. No. 35 .

A 9,443 .

B 143, vol. 3, pp. 149166.

167.

177.

Menomini Indians, The (Hoffman) .............. A 14,3.

Mesa Verde National Park, Antiquities of:

Ciifi Palace (Fewlies) _. . . . . . . . . . . . . . . . . .

Spruce-tree House (Fewkes) _............... B

Meso-American Division, The (Johnson) ............ B

Mestizos of South America (Steggerda)

51.

41.

143, vol. 4, pp. 199204.

B 143, vol. 6, pp. 105109. 
Mestizo types, Brazilian (Pourchet)

Metallurgy (Root)

Metals, use of gold and other, among the ancient inhabitants of Chiriqui (Holmes).

\section{Metcalf, George:}

Small sites in and about Fort Berthold Indian Reservation, Garrison Reservoir, North Dakota. In press.

Star Village: A fortified historic Arikara site in Mercer County, North Dakota. In press.

\section{Métraux, Alfred:}

Bark eloth

Boys' initiation rites

Ethnography of the Chaco.

Jesuit missions in South America

Religion and shamanism

Rubber

The Botocudo

The Caingang

The couvade

The Fulnio

The Guaitací

The Guarani

The Guató

The hunting and gathering tribes of the Rio Negro Basin.

The native tribes of eastern Bolivia and western Matto Grosso.

The Paressí

The Puri-Coroado linguistic family

The Teremembe

The Tupinamba

Tribes of eastern Bolivia and the Madeira head- B waters.
B

143 , vol. 6 , pp. 111 120.

143 , vol. 5, pp. $205-$ 225.

3.

B 185, Riv. Bas. Surv. Pap. No. 26.

185, Riv. Bas. Surv. Pap. No. 27.

B 143 , vol. 5 , pp. $67-$ 68.

B 143, vol. 5, pp. 375382.

B 143, vol. 1, pp. 197370.

B 143, vol. 5, pp. 645653.

B 143, vol. 5, pp. 559599.

B 143, vol. 5, pp. 227228.

B 143, vol. 1, pp. 531540.

B 143, vol. 1, pp.445475.

B 143, vol. 5, pp. 369374.

143, vol. 1, p. 571.

B 143 , vol. 1 , pp. 521 522.

B 143, vol. 3, pp. 6994.

B 143, vol. 1, pp. 409418.

B 143, vol. 3, pp. 861867.

134.

B 143 , vol. 3, pp. $349-$ 360.

B 143, vol. 1, pp. 523530.

B 143, vol. 1, pp. 573574.

B 143, vol. 3, pp. 95133.

143 , vol. 3 , pp. 381454. 


\section{Métraux, Alfred-Continued}

Tribes of the eastern slopes of the Bolivian Andes.-

Tribes of the Juruá-Purús Basins

Tribes of the middle and upper Amazon River ...

Warfare, cannibalism, and human trophies.

Weapons

and Baldus, Herbert. The Guayakí

and Kirchhof, Paul. The northeastern extension of Andean culture.

and Nimuendajú, Curt:

The Camacan linguistic family

The Mashacilí, Patasho, and Malali linguistic families.

See also Armstrong, John M., and Métraux, Alfred;

Nimuendajá, Curt, and Métraux, Alfred; and

Steward, Julian H., and Métraux, Alfred.

Mexican and Central American antiquities and calendar systems (Seler and others).

Mexican and Maya manuscripts, Notes on certain (Thomas).

Mexico:

and Central America, Indian languages of (Thomas and Swanton).

eastern, Certain antiquities of (Fewkes) ..........

northeastern, Linguistic material from the tribes of southern Texas and (Swanton).

northern, Physiological and medical observations among the Indians of (Hrdlička).

Numeral systems of (Thomas) ................

southern, Stone monuments of (Stirling) ..........

Veracruz, Cerro de las Mesas, ceramic stratigraphy (Drucker).

Veracruz, Tres Zapotes, ceramic sequences (Drucker).

Veracruz, Tres Zapotes, Ceramics of (Weiant).....

Yucatan, A description of thirty towns in (Steggerda).

Mexico D. F., Excavation of a site at Santiago B Ahuitzotla (Tozzer).

\section{Michelson, Truman:}

Autobiography of a Fox Indian woman ..........

Contributions to Fox ethnology ...............

Contributions to Fox ethnology-II .............

Fox miscellany . . . . . . .

Linguistic classification of Cree and MontagnaisNaskapi Dialects.
B 143 , vol. 3, pp. 465506.

B 143, vol. 3, pp. 657686.

B 143 , vol. 3, pp. $687-$ 712 .

B 143, vol. 5, pp. 383409.

B 143 , vol. 5, pp. 229263.

B 143 , vol. 1, pp. 435444.

B 143, vol. 4, pp. 349369.

B 143 , vol. 1 , pp. $547-$ 552.

B 143, vol. 1, pp. 541545.

28.

3, 3.

B 44 .

A 25, 221.

B 127.

B 34.

A 19,853 .

B 138 .

B 141.

140.

139.

136, Anthrop. Pap. No. 30 .

74.

A $40,291$.

B 85 .

B 95 .

B 114.

B 123, Anthrop. Pap. No. 8. 


\section{Michelson, Truman-Continued}

Mythical origin of the White Buffalo dance of the Fox Indians.

Notes on Fox mortuary customs and beliefs

Notes on the Buffalo-head dance of the Thunder gens of the Fox Indians.

Notes on the Fox society known as "Those Who Worship the Little Spotted Buffalo."

Notes on the Fox Wâpanōwiweni..............

Observations on the Thunder dance of the Bear gens of the Fox Indians.

Owl sacred pack of the Fox Indians, The ........

Preliminary report on the linguistic classification of Algonquian tribes.

Traditional origin of the Fox society known as "The Singing Around Rite."

What happened to Green Bear who was blessed with a sacred pack.

See also Bulletin 40 (pt. 1).

Midē'wiwin or "Grand Medicine Society" of the Ojibwa, The (Hoffman).

Migration traditions, Tusayan (Fewkes) ..............

Miller, Carl F.

Archeological manifestations in the Toole County section of the Tiber Reservoir Basin, Montana. In press.

Archeology of the John H. Kerr Reservoir Basin, Roanoke River, Virginia-North Carolina. With appendix by Lucile E. Hoyme and William M.

Bass. In press.

Revaluation of the Eastern Siouan problem, with particular emphasis on the Virginia branchesthe Occaneechi, the Saponi, and the Tutelo.

The excavation and investigation of Fort Lookout Trading Post II (39LM57) in the Fort Randall Reservoir, South Dakota.

Mills, John E. Historic sites archeology in the Fort Randall Reservoir, South Dakota.

\section{Mindeleff, Cosmos:}

Aboriginal remains in Verde Valley, Arizona.....

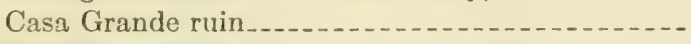

Cliff ruins of Canyon de Chelly, Arizona_........

Localization of Tusayan clans_.................

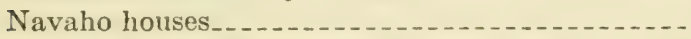

Repair of Casa Grande ruin in 1891

Mindeleff, Victor. A study of pueblo architecture: Tusayan and Cibola.

Mining of gems and ornamental stones by American Indians (Ball).

Mishkin, Bernard. The contemporary Quechua.....

Miskito and Sumu Indians of Honduras and Nicaragua, Ethnographical survey of the (Conzemius).

A $40,23$.

A $40,351$.

B 87.

A 40,497 .

B 105.

B 89.

B 72.

A 28,221 .

A 40,541 .

B 119, Anthrop. Pap. No. 4.

A 7, 143 .

A 19,573 .

B 185, Riv. Bas. Surv. Pap. No. 32.

B 182, Riv. Bas. Surv. Pap. No. 25.

B 164, Anthrop. Pap. No. 52.

B 176, Riv. Bas. Surv. Pap. No. 17.

B

176, Riv. Bas. Surv. Pap. No. 16.

A $\quad 13,179$.

A $\quad 13,289$.

A 16,73 .

A 19,635 .

A $\mathbf{1 7}, 469$.

A 15,315 .

A 8,3 .

B 128, Anthrop. Pap. No. 13.

B 143, vol. 2, pp. 411470 .

106. 
Missions, Indian, north of Mexico (Mooney)

Missions, Jesuit, in South America (Métraux)

Mississippi, archeological survey of Pickwick Basin in (Webb and DeJarnette).

Mississippi, Pickwick Basin, geology of (Jones) _.......

Mississippi Valley:

Ancient pottery of the (Holmes)

Animal carvings from mounds of the (Henshaw) -.

Lower, Indian tribes of (Swanton) ............

Missouri, central:

Cave explorations in the Ozark region of (Fowke). and southeastern, Antiquities of (Fowke) ........

Missouri, the Upper, Indian tribes of (Denig)

Missouri River, Explorations along the (Fowke) .......

Missouri River region, Uses of plants by Indians of (Gilmore).

Mnemonic and recording devices (Bennett) ........

Moche: a Peruvian coastal community (Gillin) ........

Modal personality structure of the Tuscarora Indians as revealed by the Rorschach test, The (Wallace).

Moguex-Coconuco, The (Lehmann)

Mohave ethnopsychiatry and suicide: The psychiatric knowledge and the psychic disturbances of an Indian tribe (Devereux).

Mohegan-Pequot diary, Native tribes and dialects of Connecticut: A (Speck).

Mollusks found in the shell mounds of the Pickwick Landing Basin in the Tennessee River valley (Morrison).

Montagnais-Naskapi dialects, linguistic classification of (Michelson).

Montaña, Tribes of the: An introduction (Steward)...

Montaña, Tribes of the Peruvian and Ecuadorian (Steward).

Monuments of southern Mexico, Stone (Stirling)......

Mooney, James:

Calendar history of the Kiowa Indians

Indian missions north of Mexico

Linguistic families of Indian tribes north of Mexico

Linguistic families of Indian tribes north of Mexico

Myths of the Cherokee.....

Sacred formulas of the Cherokees..............

Siouan tribes of the East_..........

The Ghost-dance religion, and the Sioux out-break of 1890 .

and Olbrechts, Frans M. The Swimmer manuscript: Cherokee sacred formulas and medicinal prescriptions, by James Mooney; revised, completed and edited by Frans M. Olbrechts.
M 9.

B 143, vol. 5, pp. 645653.

129, pp. 1-325.

129,327 .

4,361 .

2,117 .

43.

76.

37.

46,375 .

76.

33, 43.

B 143, vol. 5, pp. 611619.

3.

150.

143, vol. 2, pp.969974.

B

175.

43, 199.

129,337 .

123.

143, vol. 3, pp. 507533.

143, vol. 3, pp. 535656.

B 138 .

A 17, 129.

M 9.

M 3.

A 19, 3 .

A 7, 301.

B 22.

A 14, 641 .

B 99. 
Morgan, Lewis H. Houses and house-life of the American aborigines.

Morgan, Lewis Henry, Tonawanda longhouse cere- B monies ninety years after (Fenton).

Morley, Sylvanus G. An introduction to the study of B the Maya hieroglyphs.

Morris, Earl H. Preliminary account of the antiquities of the region between the Mancos and La Plata Rivers in southwestern Colorado.

Morrison, J. P. E. Preliminary report on mollusks found in the shell mounds of the Pickwick Basin in the Tennessee River valley.

Mortuary Customs:

and beliefs, Notes on Fox (Michelson)

Introduction to the study of (Yarrow)

of the North American Indians (Yarrow)

See also Burials.

Mosquito, Sumo, Paya, and Jicaque, The

The Caribbean Lowland tribes: (Kirchhoff).

Mound explorations of the Bureau of Ethnology (Thomas).

Mounds:

Aboriginal house (Fowke)

Burial, of the northern sections of the United States (Thomas).

Exploration of an Adena Mound at Natrium, West Virginia (Solecki).

in northern Honduras (Gann) ................

of the Mississippi Valley, Animal carvings from (Henshaw).

Ohio, The problem of the (Thomas)

prehistoric, east of the Rocky Mountains, Catalogue of (Thomas).

Ormond Beach Mound, East Central Florida (Jennings, Willey, and Newman).

Rembert mounds, Elbert County, Georgia (Cald- B well).

The Troyville, Catahoula Parish, La. (Walker)... Mountain chant: A Navajo ceremony (Matthews).... Mundurucú, The (IIorton)

Muñiz, Manuel Antonio, and McGee, W J. Primitive trephining in Peru.

Mura and Pirahá, The (Nimuendajú)

\section{Murdoch, John:}

Ethnological results of the Point Barrow expedition editor. Ethnology of the Ungava district, Hudson Bay Territory (Turner).

Murie, R. James. See Annual Report 22, pt. 2, p. 5.
4.

128, Anthrop. Pap.

No. 15.

57.

33, 155.

B 129, pp. 337-392.

A $40,351$.

J 4.

A 1,87 .

B 143 , vol. 4, pp. 219229.

A 12,$3 ;$ B 4 .

B 76.

A 5,3 .

B 151, Anthrop. Pap. No. 40.

19,655 .

2,117 .

8.

12.

164, Anthrop. Pap. No. 49.

154, 303-320.

\section{3.}

5, 379 .

B 143, vol. 3, pp. 271282.

A 16,3 .

B 143, vol. 3, pp. 255269.

A 9,3 .

A 11,159 . 
Murra, John:

The Cayapa and Colorado...................

B 143 , vol. 4, pp. 277291.

The historic tribes of Ecuador

B 143, vol. 2, pp. 785821.

Music:

Chippewa (Densmore)

B 45,53 .

Choctaw (Densmore)

B 136, Anthrop. Pap. No. 28.

Eskimo. See Boas, 6th Annual Report, pp. 648658.

IIawaiian (Emerson)

B 38.

Indians of British Columbia (Densmore)

136, Anthrop. Pap. No. 27.

Mandan and Hidatsa (Densmore)

Menominee (Densmore) ......................

Nootka and Quileute (Densmore) .................

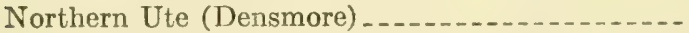

of Acoma, Isleta, Cochiti, and Zuñi Pueblos (Densmore).

Papago (Densmore)

Pawnee (Densmore)

80.

102.

124.

75.

Seminole (Densmore)

Technique in the music of the American Indian (Densmore).

Teton Sioux (Densmore)

165.

Yuman and Yaqui (Densmore) ..................

See also Songs.

Muskhogean languages, Bibliography of the (Pilling) --

Mutilation in South American Indian skeletal remains,

Deformity, trephining, and (Stewart).

Myer, William Edward:

Indian trails of the Southeast...........................

Two prehistoric villages in Middle Tennessee......

Mythical origin of the White Buffalo dance of the Fox Indians (Michelson).

Mythology:

of the North American Indians (Powell) .........

Tsimshian (Boas)

Myths:

Acoma origin (Stirling)

90.

93.

161.

151, Anthrop. Pap. No. 36.

61.

110.

9.

143, vol. 6, pp. 4348.

A 42,727 .

A 41,485 .

A $40,23$.

Alsea texts and (Frachtenberg)

and tales of the Southeastern Indians (Swanton)..

Dine, The: Origin myths of the Navaho Indians (O'Bryan).

Karuk Indian (Harrington)

Kutenai tales (Boas and Chamberlain) ...........

of the Cherokee (Mooney)

of the Haida (Swanton) . . .

of the Iroquois (Smith) _.......................

of the Tlingit (Swanton)

Seneca fiction, legends, and (Curtin and Hewitt) _- A

A $1,17$.

A 31,29

B 135 .

B 67.

B 88 .

B 163.

B 107.

B 59.

A 19,3 .

B 29.

A 2,47 .

B 39 .

A 32,37 . 
Myths-Continued

Shoshoni, Some western (Steward)

B 136, Anthrop. Pap.

No. 31 .

Zuñi creation, Outlines of (Cushing) ............ A $13,321$.

Zuñi origin (Bunzel) _.................. A 47,545 .

Nambicuara, The (Lévi-Strauss)

B $\quad 143$, vol. 3 , pp. $361-$ 369.

Narcotics, Stimulants and (Cooper)

Natick dictionary (Trumbull), with introduction by Edward Everett Hale.

Native Brotherhoods, The: Modern intertribal organizations on the Northwest Coast (Drucker).

Native tribes and dialects of Connecticut: A MoheganPequot diary (Speck).

Navaho houses (C. Mindeleff)

43, vol. 5 , pp. $525-$ 558.

B 25.

B 168 .

Navaho National Monument, Arizona, visit to (Fewkes).

Navajo ceremony, The mountain chant: A (Matthews).

Navajo Indians, Ceremonial of Hasjelti Dailjis and mythical sand painting of the (J. Stevenson).

Navajo silversmiths (Matthews) ...................

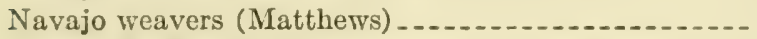

Nelson, E. W. The Eskimo about Bering Strait.....

Neuman, Robert W. Archeological salvage investigations in the Lovewell Reservoir Area, Kansas. In press.

Newman, Marshall T. Indian skeletal remains from the Doering and Kobs sites, Addicks Reservoir, Texas.

and Jennings, Jesse D. and Willey, Gordon R. The Ormond Beach Mound, East Central Florida.

and Snow, Charles E. Preliminary report on the skeletal remains from Pickwick Basin, Alabama. and Stewart, T. D. Anthropometry of South American Indian skeletal remains.

Anthropometry of the Umotina, Nambicuara, and Iranxe, with comparative data from other Northern Mato Grosso tribes.

Indian skeletal material from the Berrian's Island cists (45-BN-3), lower MeNary Reservoir, Washington (appendix 1).

New Mexico:

Excavations in the Chama Valley (Jeancon) .....

Illustrated catalogue of collections from, in 1879 (J. Stevenson).

in 1880 (J. Stevenson)

in 1881 ( $\mathrm{J}$. Stevenson)

Isleta (Parsons)

Isleta Paintings (Parsons) ...................

Jemez Plateau, Antiquities of the (Hewett) ......

A 43,199 .

A 17,469 .

B 50 .

A 5,379 .

A 8,229 .

A 2,167 .

A 3,371 .

A 18,3 .

B 185, Riv. Bas. Surv.

Pap. No. 32.

B 154, Riv. Bas. Surv.

Pap. No. 4, Pt. 2.

164, Anthrop. Pap. No. 49.

B 129, pp. 393-507.

B 143, vol. 6, pp. 1942.

P 15, 128.

B 166.

B 81 .

A 2,307 .

A 2, 423 .

$\perp \quad 3,511$.

A 47, 193.

B 181 .

B 32 . 
New Mexico-Continued

Rio Grande Valley, The physiography of the B $\mathbf{5 4}$.

(Hewett, Henderson, and Robbins).

upper Gila and Salt River valleys, Antiquities of B $\mathbf{3 5}$. the (Hough).

See also Roberts, Frank H. H., Jr.

Nicaragua:

Ethnographical survey of the Miskito and Sumu B 106.

Indians of Honduras and (Conzemius).

The archeology of Costa Rica and (Strong) _..... B 143, vol. 4, pp. 121142.

Nichols, Frances S., compiler. Index to Schoolcraft's B 152.

"Indian tribes of the United States."

Nickerson, Norton H., and Hou, Ding. Maize from the B 158, 180 .

Dodd and Phillips Ranch sites.

Nimuenda jú, Curt:

Little-known tribes of the lower Amazon

B 143, vol. 3, pp. 209-

211.

Little-known tribes of the lower Tocantins River region.

The Cayabi, Tapanyuna, and Apiaca............

The Cowahíb, Parintintin, and their neighbors...

The Maué and Arapium

B

143, vol. 3, pp. 203208.

B 143 , vol. 3, pp. 307320.

B 143, vol. 3 , pp. 283297.

B 143, vol. 3, pp. 245254.

The Mura and Pirahá...........

The Tucuna

B 143 , vol. 3 , pp. 255269.

B 143, vol. 3, pp. 713725 .

The Turiwara and Aruã

B 143 , vol. 3, pp. 193198.

Tribes of the lower and middle Xingú River.....

and Mêtraux, Alfred. The Amanayé...........

B 143 , vol. 3, pp. 213243.

B 143, vol. 3, pp. 199202.

See also Métraux, Alfred, and Nimuendajú, Curt. Niskwalli, Dictionary of the (Gibbs) ................

Nomads of the long bow: The Siriono of eastern Bolivia (Holmberg).

Nootka and Quileute music (Densmore)_............ B

Nootkan tribes, The Northern and Central (Drucker)_ B

Norris Basin in eastern Tennessee, An archeological B survey of the (Webb).

North Alaskan Eskimo, The: A study in ecology and B society (Spencer).

North Carolina:

Peachtree Mound and village site (Setzler and B 131. Jennings).

Peachtree Site, Skeletal material from (Stewart)_-_ B $\quad$ 131, 81.

North Chilean Coast, The cultural sequence of the B 143, vol.2, pp.587(Bird). 
North Chilean Coast, The historic inhabitants of the B (Bird).

North Colombia Lowlands, Tribes of the (Hernández de B Alba).

Northern and Central Nootkan tribes, The (Drucker) _- $\quad$ B

Northern Highland tribes, The: The Lenea (Stone) _... B

Northern Ute music (Densmore)

Northwest, extreme, Tribes of the (Dall)

Northwest Coast, Archeological survey on the northern (Drucker).

Notes on Fox mortuary customs and belicfs (Michelson).

Notes on the Buffalo-head dance of the Thunder gens of the Fox Indians (Michelson).

Notes on the Fox society known as "Those who Worship the Little Spotted Buffalo" (Michelson).

Notes on the Fox Wâpanōwiweni (Michelson)

Notes on the natives of Alaska (Furuhelm) ...........

Numbers, measures, weights, and calendars (Bennett)..

Numbers, Primitive (McGee) ...........

Numeral systems of Mexico and Central America (Thomas).

Numerals, Note on the use of, among the T'sim si-an' (Gibbs).

\section{Oberg, Kalervo:}

Indian tribes of northern Mato Grosso, Brazil, by Kalervo Oberg, with an appendix entitled "Anthropometry of the Umotina, Nambicuara, and Iranxe, with comparative data from other northern Mato Grosso tribes," by Marshall T. Newman.

Terena and Caduveo of southern Mato Grosso, P The.

O'Bryan, Aileen. The Dine: Orgin myths of the Navaho Indians.

Observations on some ninetcenth century pottery vessels from the Upper Missouri (Wedel).

Observations on the Thunder dance of the Bear gens of the Fox Indians (Michelson).

Ofo, Biloxi-, dictionary (Dorsey and Swanton) ........

Of the Crow Nation, by Edwin Thompson Denig (edited with biographical sketch and footnotes by John C. Ewers).

Ohio, The circular, square, and octagonal earthworks of (Thomas).

Ohio mounds, The problem of the (Thomas) ..........

Ojibwa, The Midē'wiwin or "Grand Medicine Society" of the (Hoffman).

See also Chippewa.

Olbrechts, Frans M. See Mooney, James, and Olbrechts.
143, vol. 2, pp. 595597.

143, vol. 4, pp. 329 338.

144.

143, vol. 4, pp. 205217.

B 75 .

C 1, 1.

B 133, Anthrop. Pap. No. 20.

A 40,351 .

B 87.

A 40,497 .

B 105 .

C 1,111.

B 143 , vol. 5 , pp. $601-$ 610.

A 19,821 .

A $\quad \mathbf{1 9}, 853$.

1,55 .

$\mathrm{P} \quad 15$

9.

B 163.

B 164, Anthrop. Pap. No. 51.

89.

B 47.

B 151, Anthrop. Pap.

No. 33 .

B 10.

B 8 .

A 7,143 . 
Omaha and Ponka letters (Dorsey)

Omaha dwellings, furniture, and implements (Dorsey)

Omaha sociology (Dorsey)

Omaha tribe, The (Fletcher and La Flesche)

Ona, The (Cooper)

$\begin{array}{ll}\text { B } & 11 . \\ \text { A } & 13,263 . \\ \text { A } & 3,205 . \\ \text { A } & 27,17 . \\ \text { B } & 143, \text { vol. } 1, \text { pp. } 107- \\ & 125 .\end{array}$

O'Neale, Lila M.:

Basketry

Weaving

143, vol. 5, pp. 6996.

B 143, vol. 5, pp. 97138.

Oregon, northwestern, Tribes of (Gibbs)

$1,157$.

Oregon, southwestern, The Klamath Indians of (Gatschet).

Orinoco River, The tribes north of the (Kirchhofi)

Ormond Beach Mound, East Central Florida (Jennings, Willey, and Newman).

Ortíz, Sergio Elias:

The modern Quillacinga, Pasto, and Coaiquer...-

The native tribes and languages of southwestern Colombia.

Osage language, A dictionary of the (La Flesche) ......

Osage traditions (Dorsey) ............................. A

Osage tribe:

Rite of the chiefs; sayings of the ancient men, The (La Flesche).

Rite of the Wa-xo'-be, The (La Flesche) .........

The rite of vigil (La Flesche)

Two versions of the child-naming rite (La Flesche).

War ceremony and peace ceremony of (La Flesche).

\section{Osborne, Douglas:}

Excavations in the McNary Reservoir Basin near Umatilla, Oregon. With appendixes by Marshall T. Newman, Arthur Woodward, W. J. Kroll, and B. H. McLeod.-

and Bryan, Alan, and Crabtree, Robert $H$. The Sheep Island site and the mid-Columbia Valley.

Ospina, Gabriel, see Foster, George M.

Otomac, The (Kirchhoff)

Owl sacred pack of the Fox Indians, The (Michelson) -Ozark region of central Missouri, Cave explorations in the (Fowke).

Painting, face and body. Sce Teit, James A.

Paiute, Panatübiji', and Owens Valley (Steward) .....

Palerm, Angel, and Keliy, Isabel. The Tajin Totonac:

2.

B 143, vol. 4, pp. 481493.

B 164, Anthrop. Pap. No. 49.

B 143, vol. 2, pp. 961968.

B 143, vol. 2, pp. 911914.

B 109 .

A 6,373 .

A $\quad 36,37$.

A $45,523$.

A 39, 31 .

A 43,23 .

B 101.

B 166, Riv. Bas. Surv. Pap. No. 8.

B 179, Riv. Bas. Surv. Pap. No. 24.

B 72 .

B 76.

43, vol. 4, pp. 439444.

Part 1. History, subsistence, shelter, and technology. No. 6. 
Pampean Hunters, The Patagonian and (Cooper)....-

Pamunkey Indians of Virginia (Pollard)

Panamá, The archeology of (Lothrop)

Panama Canal, The tribes west and south of the (Lothrop).

Panatübiji', an Owens Valley Paiute (Steward) ........

Pancararú, The (Lowie)

Papago music (Densmore)

Paraná Delta and La Plata Littoral, Indians of the (Lothrop).

Paraná River, The archeology of the (Aparicio)

Paressí, The (Métraux)

Parintintin, and their neighbors, The Cawahíb (Nimuendajú).

Park, Willard Z. Tribes of the Sierra-Nevada de Santa Marta.

\section{Parsons, Elsie Clews.}

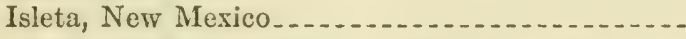

Isleta paintings, with introduction and commentary by. Edited by Esther S. Goldfrank. In press.

Pasto, and Coaiquer, The modern Quillacinga (Ortíz)_

Patagonia, The archeology of (Bird)

Patagonian and Pampean Hunters, The (Cooper).....-

Patángoro and Amani, The (Kirchhoff)

Patashó linguistic families. See Mashacali, Patasho, and Malalí linguistic families (Métraux and Nimuendajú).

Pathological changes in South American Indian skeletal remains (Stewart).

Pathology of Chile, The geographical (Herzog) ........

Pawnee archeology, An introduction to (Wedel) .......

Pawnee ceremony, The Hako: A (A. C. Fletcher) ....-

Pawnee music (Densmore)

Paya, and Jicaque, The Mosquito, Sumo. The Caribbean Lowland tribes: (Kirchhofí).

Peachtree Mound and village site, Cherokee County, North Carolina (Setzler and Jennings).

Peachtree Site, North Carolina, Skeletal material from (Stewart).

Peban tribes, The (Steward and Métraux) ............

Penny capitalism, a Guatemalan Indian economy (Tax)_ $\quad P$
143, vol. 1, pp. 127168.

17.

143 , vol. 4 , pp. $143-$ 167.

143, vol. 4, pp. 253256.

119, Anthrop. Pap. No. 6.

143, vol. 1, p. 561 . 90.

143, vol. 1, pp. 177190.

143, vol. 3, pp. 5767.

143, vol. 3, pp. 349360.

143, vol. 3, pp. 283297.

143, vol. 2, pp. 865886.

A $47,193$.

B 181 .

143, vol. 2, pp. 961968.

143, vol. 1 , pp. 1724.

143, vol. 1, pp. 127168.

I 143, vol. 4, pp. 339348.

143, vol. 6, pp. 4952.

143, vol. 6, pp. 137144.

112.

22 (pt. 2), 5.

93.

143 , vol. 4, pp. 219229.

131.

131,81 .

143 , vol. 3 , pp. $727-$ 736.

16. 
Perforated stones from California (Henshaw)

Perú:

A culture sequence for the North Coast of (Larco Hoyle).

Primitive trephining in ancient (Muñiz and
McGee).

Social and economico-political evolution of the communities of Central (Castro Pozo).

Textile fabrics of ancient (Holmes)

Peruvian civilization, The quipu and (Swanton)

Petroglyphs (Rouse)

Petrology of artifacts and architectural stone at La B Venta, The (Curtis) (appendix 4).

\section{Petrullo, Vincenzo:}

Archeology of Arauquin

The Yaruros of the Capanaparo River, Venezuela.

Philology, or the science of activities designed for expression (Powell).

Physical anthropology of the internal organs among the races of Chile (Henckel).

Physical anthropology of the Lenape or Delawares, and of the eastern Indians in general (Hrdlicka).

Physiography, The, of the Rio Grande Valley, New Mexico, in relation to Pueblo culture (Hewett, Henderson, and Robbins).

Physiological and medical observations among Indians of southwestern United States and northern Mexico. (Hrdlička).

Pickwick Basin, Alabama, Skeletal material from (Newman and Snow)

Pickwick Basin, An archeological survey of (Webb and DeJarnette).

Pickwick Basin, Geology of (Jones)

Pickwick Basin Landing in the Tennessee River Valley, Mollusks found in shell mounds of (Morrison).

Pickwick pottery, A description and analysis of the (Haag).

Pictographs of the North American Indians (Mallery).

Picture-writing:

Of the American Indians (Mallery)

Studies in Central American (Holden)

Picuris children's stories, with texts and songs (Harrington and Roberts).

Pierson, Donald. Cruz das Almas: A Brazilian village Pigmentation and hair of South American Indians, The (Steggerda).
B 2 .

B 143, vol. 2, pp. 149175.

16,3 .

B 143, vol. 2, pp. 483499.

7.

133, Anthrop. Pap.

No. 26.

B 143, vol. 5, pp. 493502.

170.

B 123, Anthrop. Pap.

No. 12.

B 123, Anthrop. Pap.

No. 11.

A 20, cxxxix.

B

143, vol. 6, pp. 145156.

62.

B 54.

B

34.

$129,393$.

129.

$129,327$.

$129,337$.

B $\quad 129,509$.

A 4,3 .

A 10, 3.

A 1, 205.

A $\quad 43,289$.

P 12.

B 143 , vol. 6 , pp. 8590 . 
Pilling, J. C.:

Bibliography of the Algonquian languages.......

Bibliography of the Athapascan languages.......

Bibliography of the Chinookan languages.........

Bibliography of the Eskimo language............

Bibliography of the Iroquoian languages..........

Bibliography of the Muskhogean languages......-

Bibliography of the Salishan languages...........

Bibliography of the Siouan languages.

B 13.

B 14.

B 15.

B 1.

B 6 .

B 9.

Bibliography of the Wakashan languages_....... B 19.

Catalogue of linguistic manuscripts in the library of A $\mathbf{1 , 5 5 3 .}$

the Bureau of Ethnology.

Proof-sheets of a bibliograhpy of the languages of the North American Indians.

Pima Indians, The (Russell) _....................

Pipe, northern Arapaho flat, and the ceremony of covering the pipe (Carter).

Pirahí, The Mura and (Nimuendajú)

M 2.

A 26,3 .

B 119, Anthrop. Pap. No. 12.

B 143 , vol. 3, p९. 255269.

Plains Apache archeology, An introduction to-the Dismal River Aspect (Gunnerson).

Plants, Uses of:

By Indians of the Missouri River region (Gilmore) -

By the Chippewa Indians (Densmore) ............

Plants, Yucatan, Some ethnological data concerning one hundred (Steggerda).

Plants in tropical South America, The use of wild (LéviStrauss).

Plants of South and Central America, Cultivated (Sauer).

Pleasure; Esthetology, or the science of activities designed to give (Powell).

Poetry, Zuñi ritual (Bunzel) ...........................

Point Barrow expedition, Ethnological results of the (Murdoch).

Political organization of the Andean peoples, The social and (Kirchhoff).

Political organization of the Tropical Forest and Marginal tribes, Social and (Lowie).

Pollard, J. G. The Pamunkey Indians of Virginia_..-

Ponka and Omaha letters (Dorsey) ..................

Popayán region, Colombia, The archeology of the (Lehmann).

Population of South America, The native (Steward)....

Porto Rico and neighboring islands, Aborigines of (Fewkes).

Potomac and James Valleys, Archeologic investigations in (Fowke).

Potomac-Chesapeake tidewater province, Stone implements of (Holmes).

173, Anthrop. Pap. No. 58 .

A 33,43 .

A $44,275$.

B 136, Anthrop. Pap. No. 29.

B 143, vol. 6, pp. 465486.

143 , vol. 6 , pp. $465-$ 486.

19, LV.

A $\quad 47,611$.

A 9,3 .

B 143, vol. 5, pp. 293340.

B 143, vol. 5, pp. 313350.

B 17.

B 11.

B 143, vol. 2, pp. 861864.

B 143, vol. 5, pp. $655-$ 668.

A 25, 3 .

B 23.

A $\quad \mathbf{1 5}, 3$. 
Pottery:

Aboriginal, of the eastern United States (Holmes) Ancient, of the Mississippi Valley (Holmes) Designs on prehistoric Hopi (Fewkes)

A $20,3$.

A 4, 361 .

of the ancient Pueblos (Holmes)

A 33, 208.

A $4,257$.

Prehistoric textile fabrics of the United States, A $\mathbf{3}, 393$. derived from impressions on (Holmes).

Pueblo, as illustrative of Zuni culture-growth (Cushing).

Vessels from the Upper Missouri, Observations on some nineteenth century (Wedel).

Pourchet, Maria Julia. Brazilian Mestizo types

Powell, J. W.:

Esthetology, or the science of activities designed to give pleasure.

Indian linguistic families of America north of Mexico.

Introduction to the study of Indian languages, with words, phrases, and sentences to be collected.

Map of linguistic stocks of American Indians north of Mexico.

() n activital similarities

On limitations to the use of some anthropologic data.

On regimentation

On the evolution of language

Philology, or the science of activities designed for expression.

Sketch of the mythology of the North American Indians.

Sociology, or the science of institutions

Sophiology, or the science of activities designed to give instruction.

Technology, or the science of industries

Wyandot government: A short study of tribal society.

editor. Linguistics [of the tribes of California] - -

Powers, Stephen. Tribes of California._............

Preceramic and ceramic cultural patterns in northwest

Virginia (Holland).

Prehistoric island culture area of America, A (Fewkes).

Prehistoric settlement pattern in the Virú Valley, Peru (Willey).

Prehistoric sites in the region of Flagstaff, Arizona, A B survey of (Colton).

Prehistoric trephining and cranial amulets (R. Fletch- C er).

Prehistoric villages, castles, and towers of southwestern B Colorado (Fervkes).

Prehistory and the Missouri Valley development program: summary report on the Missouri River Basin archeological survey in 1948 (Wedel).
A 4, 467.

B 164, Anthrop. Pap. No. 51.

B 143, vol. 6, pp. 111120.

$\Lambda \quad 19, \mathrm{LV}$.

$7,1$.

1 and 2.

$4,7$.

3, LXV.

1,71 .

15, CIV.

$1,1$.

20, $\operatorname{cxxxIx.~}$

1,17 .

A 20, LIX.

A 20, cLXXI.

A 20, xxix.

1,57 .

C 3,439.

C 3.

B 173, Anthrop. Pap. No. 57.

34,35 .

155.

104.

5.

70.

B 154, Riv. Bas. Surv. Pap. No. 1. 
Prehistory and the Missouri Valley development program: summary report on the Missouri River Basin archeological survey in 1949 (Wedel).

Primitive man in Argentina, The present status of the theories concerning (Frenguelli).

Primitive numbers (McGee)

Problem of the Ohio mounds, The (Thomas) .........

Projectile points and large blades, An analysis of (Holland).

Proof-sheets of a bibliography of the languages of the North American Indians (Pilling).

Property among the Tropical Forest and Marginal B tribes (Lowie).

Psychological determinants of culture change in an Iroquoian community, Some (Wallace).

Publications of the Bureau of American Ethnology, List of.

Pueblo architecture: Tusayan and Cibola (V. Mindeleff).

Pueblo culture, The physiography of the Rio Grande Valley, New Mexico, in relation to (Hewett and others).

Pueblo of Sia, New Mexico, The (White). In Press_. Pueblo pottery as illustrative of Zuñi culture growth (Cushing).

Pueblo ruins, Early, in the Piedra district, southwestern Colorado (Roberts).

Pueblo ruins, Two summers' work in (Fewkes) ........ Pueblos, ancient, Pottery of the (Holmes)

Puerto Rico, The ethnography of (Hostos)

Puna and the Quebrada de Humahuaca, The cultures of the (Casanova).

Purf-Coroado linguistic family, The (Métraux) .......

Quarry, Ancient, in Indian Territory (Holmes) ....... Quebrada de Humahuaca, The cultures of the Puna and the (Casanova).

Quechua, The contemporary (Mishkin) ............

Quechua in the Colonial world, The (Kubler).........

Quichua-speaking Indians of the Province of Imbabura (Ecuador) and their anthropometric relations with the living populations of the Andean area (Gillin). Quileute music, Nootka and (Densmore)............. Quillacinga, Pasto, and Coaiquer, The modern (Ortiz).

Quipu and Peruvian civilization, The (Swanton) ......

Quiroga: A Mexican municipio (Brand) ..............
$\mathrm{B}$

154, Riv. Bas. Surv. Pap. No. 2.

143, vol. 6, pp. 1117.

A 19,821 .

B 8.

B 160,165 .

M 2.

143, vol. 5, pp. 351367.

149, 55-76.

$24,31,36,49,58$;

A $17,20,28,30$.

M 1944, 1949, 1956 .

A 8,3 .

B 54

B 184 .

A 4,467 .

B 96.

A 22 (pt. 1), 3.

A $4,257$.

B 143 , vol. 4, pp. 540542 .

B 143, vol. 2, pp. 619631.

B 143, vol. 1, pp. 523530 .

B 21.

B 143, vol. 2, pp. 619631.

B 143, vol. 2, pp. 411470 .

B 143, vol. 2, pp. 331410.

B 128, Anthrop. Pap. No. 16.

B 124 .

B 143, vol. 2, pp. 961968.

B 133, Anthrop. Pap. No. 26.

P 11. 
Races of Chile, The physical anthropology of the internal organs among the (Henckel).

Radin, Paul. The Winnebago tribe.

Randle, Martha Champion. See Fenton, William N., editor.

Rands, Robert L.:

Some manifestations of water in Mesoamerican art.

The water lily in Maya art: A complex of alleged Asiatic origin.

Rau, Charles. Observations on cup-shaped and other lapidarian sculptures in the Old World and in America. Recording devices, Mnemonic and (Bennett)

Redbird Smith Movement, The (Thomas) ...........

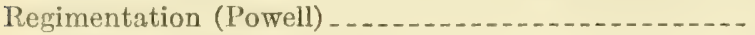

Relacion of 1746, Sedelmayr's (Ives)

Relationship, Terms of, used by the Innuit (Dall).....

Religion, Ghost-dance (Mooney)

Religion and shamanism (Métraux)

Religion of Handsome Lake: Its origin and development (Deardorff).

Religous beliefs and medical practices of the Creek Indians (Swanton).

Religious beliefs and usages of the Chickasaw Indians, Social and (Swanton).

Religious life of the Zuñi child (M. C. Stevenson) .....-

Rembert mounds, Elbert County, Georgia, The (Caldwell).

Revaluation of the Eastern Siouan problem, with particular emphasis on the Virginia branches-the Occaneechi, the Saponi, and the Tutelo (Miller).

Rice. See Wild rice.

Riesenberg, Saul H., and Shigeru, Kaneshiro. A Caroline Islands script.

Riggs, Stephen Returns:

Dakota-English dictionary, A ................

Dakota grammar, texts and ethnography ........

Illustration of the method of recording Indian languages.

Rio Grande Valley, New Mexico, The physiography of the (Hewett, Henderson, and Robbins).

Rio Negro Basin, The hunting and gathering tribes of the (Métraux).

Rise of the Cherokee State as an instance in a class, The: The "Mesopotamian" career to statehood (Gearing).

Ritchie, William A. Iroquois archeology and settlement patterns.
B 143 , vol. 6 , pp. $145-$ 156.

A 37,35 .

B 157, Anthrop. Pap.

No. 48.

B 151, Anthrop. Pap. No. 34 .

C 5 .

B 143, vol. 5, pp. 611619.

B 180, pp. 159-166.

A $15, \mathrm{CIV}$.

$B$ 123, Anthrop. Pap. No. 9.

C 1, 117.

A 14,641 .

B 143, vol. 5, pp. 559599 .

B 149, 77-107.

A 42,473 .

A $\quad 44,169$.

A $\mathbf{5 , 5 3 3 .}$

B 154, Riv. Bas. Surv. Pap. No. 6.

B 164, Anthrop. Pap. No. 52.

B 172, Anthrop. Pap. No. 60 .

C 7.

C 9.

A 1,579 .

B 54.

B 143, vol. 3 , pp. 861867.

B 180, pp. 125-134.

B $\quad 180$, pp. 25-38. 
River Basin Surveys Papers:

Nos. 1-6 $6 \ldots \ldots$ B 154.

No. 7 (whole volume) _....................... B 158.

No. 8 (whole volume) _...................... B 166.

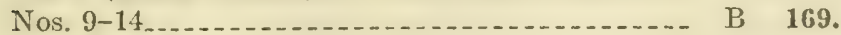

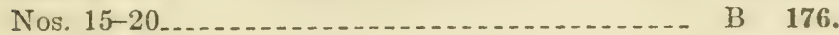

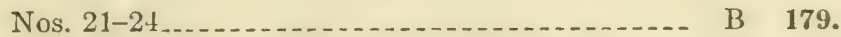

No. 25 (whole volume) In press............. B 182.

Nos. 26-32. In press.......................... 185.

Robbins, Wilfred W., and others:

Ethnobotany of the Tewa Indians_.......... B 55.

The physiography of the Rio Grande Valley, New B 54. Mexico.

Roberts, Frank H. H., Jr.

Archeological remains in the Whitewater District, B eastern Arizona. Part I: House types.

Archeological remains in the Whitewater District, B eastern Arizona. Part II. Artifacts and burials. With appendix, Skeletal remains from the Whitewater District, eastern Arizona, by T. D. Stewart.

Early Pueblo ruins in the Piedra District, southwestern Colorado.

Shabik'eshchee village, a late Basket Maker site in B the Chaco Canyon, New Mexico.

The ruins at Kiatuthlanna, eastern Arizona..... B 100.

The Village of the Great Kivas on the Zuni Reser- B 111. vation, New Mexico.

Roberts, Helen H; See Harrington, J. P., and Roberts,

Helen $\mathrm{H}$.

Roberts, Helen H., Haeberlin, H.K.; and Teit, James A. A $\quad 41,119$.

Coiled basketry in British Columbia and surrounding region.

Root, William C. Metallurgy

B 143 , vol. 5, pp. 205225.

\section{Roth, Walter E.:}

Additional studies of the arts, crafts, and customs of the Guiana Indians, with special reference to those of southern British Guiana.

An inquiry into the animism and folk-lore of the Guiana Indians.

An introductory study of the arts, crafts, and A 38, 25.

\section{Rouse, Irving:} customs of the Guiana Indians.

Petroglyphs

The Arawak.

143, vol. 5, pp. 493502.

B 143, vol. 4, pp. 507546.

The Carib

B 143, vol. 4, pp. 547565.

The Ciboney

B 143 , vol. 4, pp. 497503.

The West Indies: An introduction..............

B 143 , vol. 4, pp. 495496. 
Rowe, John Howland. Inca culture at the time of the B Spanish Conquest.

Royce, Charles C.:

Cessions of lands by Indian tribes to the United States: Illustrated by those in the State of Indiana.

Indian land cessions in the United States (with introduction by Cyrus Thomas).

The Cherokee nation of Indians: A narrative of their official relations with the Colonial and Federal governments.

Rubber (Métraux)

Ruin, Casa Grande (C. Mindelefi)

Ruin, Casa Grande, Repair of, in 1891 (C. Mindeleff) -

See also Twenty-eighth Annual Report.

Ruins:

at Kiatuthlanna, eastern Arizona (Roberts) ......Cliff, of Canyon de Chelly (C. Mindeleff) .........

Early Pueblo, in the Piedra district, southwestern Colorado (Roberts).

pueblo, Two summers' work in (Fewkes) ........

Russell, Frank. The Pima Indians

Sacred formulas and medicinal prescriptions, Cherokee,

The Swimmer manuscript: (Mooney and Olbrechts).

Sacred formulas of the Cherokees (Mooney) ...........

Sacred pack, What happened to Green Bear who was

blessed with a (Michelson).

Sacred pack of the Fox Indians, The Owl (Michelson) ..

Sae, The Guayupé and (Kirchhoff)

Salishan languages, Bibliography of the (Pilling)......

Salishan tribes of the western plateaus, The (Teit) ...-

Salt River, upper Gila and, valleys, Antiquities of the (Hough).

Sambaquís of the Brazilian coast, The (Serrano).......

San Agustín and Tierradentro, Colombia, The archeology of (Hernández de Alba).

Sand painting of the Navajo Indians, Mythical (J. A

Stevenson).

Sapir, Edward. See Bulletin 40 (pt. 2).

Sapper, Carl, and others. Mexican and Central B

American antiquities, calendar systems, and history.

Sauer, Carl O.:

Cultivated plants of Central and South America..-

The geography of South America

Schellhas, Paul, and others. Mexican and Central American antiquities, calendar systems, and history. Schoolcraft's, "Indian tribes of the United States", Index to compiled by Frances S. Nichols.
143, vol. 2 , pp. $183-$ 330.

A $1,247$.

A 18,521 .

A 5,121 .

143 , vol. 5 , pp. 227 228.

A $\quad 13,289$.

A 15, 315 .

B 100 .

A 16,73 .

B 96 .

A 22 (pt. 1), 3.

A 26, 3 .

B 99.

A 7, 301 .

B 119, Anthrop. Pap. No. 4.

72.

143, vol. 4, pp. 385391.

16.

45, 23.

35.

B 143, vol. 1, pp.401407.

143, vol. 2, pp. 851859.

8, 229 .

28.

B 143, vol. 6, pp. 465486.

B 143, vol. 6, pp. 319344.

B 28 .

B 152 . 
Sculptures, cup-shaped and other lapidarian, Observations on (Rau).

Sears, William $\mathbf{H}$.

The Wilbanks site $(9 \mathrm{CK}-5)$, Georgia............

First comment on William A. Ritchie's "Iroquois B

Archeology and Settlement Patterns."

Second comment on Charles H. Holzinger's "Some Observations on the Persistence of Aboriginal Cherokee Personality Traits" (Gulick).

Second comment on William A. Ritchie's "Iroquois Archeology and Settlement Patterns" (Byers).

Sedelmayr's Relación of 1746 (Ives)

Seler, Eduard, and others. Mexican and Central American antiquities, calendar systems, and history.

Seminole Indians of Florida, The (MacCauley) ........ Seminole music (Densmore)

Seneca fiction, legends, and myths, collected by Jeremiah Curtin and J. N. B. Hewitt (edited by J. N. B. Hewitt).

Seneca Thanksgiving rituals (Chafe)
Serian and Yuman languages. See Comparative lexicology of (Hewitt).

Seri Indians, The (McGee)

Serrano, Antonio:

Sambaquís of the Brazilian coast

The Charrua,

Setzler, Frank M., and Jennings, Jesse D. Peachtree Mound and village site, Cherokee County, North Carolina.

Shabik'eshchee village, a late Basket Maker site in the Chaco Canyon, New Mexico (Roberts).

Shamanism, Religion and (Métraux) ..............

Sheep Island site, The, and the mid-Columbia Valley, (Osborne, Bryan, and Crabtree).

Shell, Art in, of the ancient Americans (Holmes) .....Shepard, Anna O. See Drucker, Philip.

Shigeru, Kaneshiro, and Riesenberg, Saul H. A B Caroline Islands script.

Shimkin, D. B. The Wind River Shoshone Sun Dance-

\section{Shimony, Annemarie:}

Comment on Fred O. Gearing's "The Rise of the Cherokee State as an Instance in a Class: The 'Mesopotamian' Career to Statehood."

The Iroquois fortunetellers and their conservative influence.
5.

B 169, Riv. Bas. Surv.

Pap. No. 12.

180, pp. 39-43.

180, pp. 247-252.

180, pp. $45-50$.

B) 123, Anthrop. Pap. No. 9.

28.

5, 469 .

161.

$32,37$.

183.

17, 299*.

A $17,1$.

B 143, vol. 1, pp. 401407.

B 143, vol. 1, pp. 191196.

B 131.

92.

B 143, vol. 5, pp. 559599.

179, Riv. Bas.

Surv. Pap. No.

24.

A $\quad 2,179$.

173, Anthrop Pap. No. 60.

151, Anthrop. Pap.

No. 41.

B 180, pp. 135-138.

B 180,pp. 205-211. 
Shiner, Joel L. The McNary Reservoir: A study in B Plateau archeology.

Shoshoni, Lemhi, physical therapy (Steward) .......-

Shoshoni, myths, Some western (Steward)

Sia, The (M. C. Stevenson)

Sia Pueblo, New Mexico, see Pueblo of Sia, New Mexico, The

Sierra Nevada de Santa Marta, Colombia, Tribes of the B (Park).

Sierra Popoluca speech (Foster and Foster) -

Sierras de Córdoba, The Comechingón and their neighbors of the (Aparicio).

Signals, gesture-signs and, of the North American M 1

Indians (Mallery).

Sign language:

among North American Indians (Mallery) ....... Introduction to the study of, among North American Indians (Mallery).

Silversmiths, Navajo (Matthews)

Similarities, On activital (Powell)

Siouan, Algonquian, and Caddoan tribes west of the Mississippi, Burials of the (Bushnell).

Siouan, Algonquian, and Caddoan tribes west of the Mississippi, Villages of the (Bushnell).

Siouan eults, A study of (Dorsey) ...............

Siouan Indians, The (McGee)

Siouan languages, Bibliography of the (Pilling) _...... See also Bulletin 40 (pt. 1).

See also Dakota.

Siouan sociology (Dorsey) -

Siouan tribes of the east (Mooney) - -

Sioux music. See Teton Sioux.

Sioux outbreak of 1890 (Mooney) .................

Sirion6, The (Holmberg) $\ldots \ldots \ldots$

Sirion 6 of eastern Bolivia, The (Holmberg)

Skeletal material from Missouri mounds (Hrdlička) ...

Skeletal material from Pickwick Basin, Alabama, Preliminary report on (Newman and Snow).

Skeletal remains, Anthropometry of South American Indian (Stewart and Newman).

Skeletal remains, Deformity, trephining, and mutilation in South American Indian (Stewart).

Skeletal remains, Pathological changes in South American Indian (Stewart).

Skeletal remains from the Buena Vista sites, California

Skeletal remains from the Peachtree Site, North Carolina (Stewart).

Skeletal remains from the Whitewater District, eastern Arizona (Stewart).
179, Riv. Bas.

Surv. Pap. No. 23.

B 119, Anthrop. Pap. No. 5.

B 136, Anthrop. Pap. No. 31 .

A 11,3 .

184.

143, vol. 2 , pp. 865886.

8.

143, vol. 2, pp. 673685.

1.

A 1,263 .

3.

A 2,167 .

A 3, LXv.

B 83 .

B 77.

A 11,351 .

A 15, 153.

B 5 .

A $15,205$.

B 22 .

A 14,641 .

B 143, vol. 3, pp. 454463.

10.

B $37,103$.

B 129,393 .

B

143, vol. 6, pp. 1942.

143, vol. 6, pp. 4347.

143, vol. 6 , pp. 4952.

$130,172$.

B 131,81 .

B 126,153 . 
Skeletal remains suggesting or attributed to early man B in North America (Hrdlička).

See also Bulletin 66.

Skulls from British Honduras, Report on two (Cave).

Small sites in and about Fort Berthold Indian Reservation, Garrison Reservoir, North Dakota (Metcalf). In press.

Smith, Carlyle S:

Cartridges and bullets from Fort Stevenson, North Dakota (appendix).

and Grange, Roger T., Jr. The Spain site (39LM301), a winter village in Fort Randall Reservoir, South Dakota.

Smith, Erminnie A. Myths of the Iroquois

Smith, G. Hubert.

Archeological investigations at the site of Fort Stevenson (32ML1), Garrison Reservoir, North Dakota. With appendix by Carlyle S. Smith.

Fort Pierre II (39ST217), a historic trading post in the Oahe Dam area, South Dakota.

Snake and Flute ceremonies, Tusayan (Fewkes) ...... Snake ceremonies, Tusayan (Fewkes)

Snow, Charles E. See Newman, Marshall T., and Snow, Charles E.

Snyderman, George S. See Fenton, William N., editor. Social and ceremonial life of the Choctaw Indians, Source material for the (Swanton).

Social and economico-political evolution of the communities of Central Perú (Castro Pozo).

Social and political organization of the Andean peoples, The (Kirchhoff).

Social and political organization of the Tropical Forest and Marginal tribes (Lowie).

Social and religious beliefs and usages of the Chickasaw Indians (Swanton).

Social organization and social usages of the Indians of the Creek Confederacy (Swanton).

Sociology, Omaha (Dorsey)

Sociology, or the science of institutions (Powell)

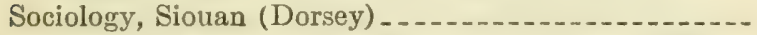

Sociopolitical groups, Basin-plateau aboriginal (Steward).

Solecki, Ralph S. Exploration of an Adena Mound at Natrium, West Virginia.

Some manifestations of water in Mesoamerican art B (Rands).

Some observations on the persistence of aboriginal B Cherokee personality traits (Holzinger).
33.

B 123, Anthrop. Pap.

No. 7, pp. 59-60.

B 185, Riv. Bas.

Surv. Pap. No.

26.

B 176, Riv. Bas. Surv. Pap. No.

19.

B 169, Riv. Bas.

Surv. Pap. No.

11.

A 2,47 .

B 176, Riv. Bas.

Surv. Pap. No.

19.

B 176, River Basin

Surv. Pap. No.

18.

A 19,957 .

A 16,267 .

B 103

B 143, vol. 2, pp. 483499.

143 , vol. 5, pp. 293311.

B 143, vol. 5, pp. 313350.

A $\quad 44,169$.

A 42,23 .

A 3, 205.

A $20, \mathrm{LIX}$.

A $15,205$.

B 120 .

B

151, Anthrop. Pap. No. 40.

157, Anthrop. Pap.

No. 48.

180, pp. 227-237. 
Songs:

Hawaiian. Sec Bulletin 38.

Ojibway. See Hoffman, 7th Annual Report.

Osage. See La Flesche, Bulletin 101.

Pawnee. See Fletcher, 22d Annual Report.

Picuris children's stories with texts and (Harring- A $\mathbf{4 3}, 289$.

ton and Roberts).

Search for, among Chitimacha Indians in Louisiana (Densmore).

See also Music.

Sophiology, or the science of activities designed to give A CLxxI.

instruction (Powell).

South America:

Antiquity of man in (McCown)

Early man in (Hrdlička and others)

B 143, vol. 6, pp. 1-9.

Fauna and ethnozoology of (Gilmore)

52.

Mestizos of (Steggerda)

The geography of (Sauer)

B 143, vol. 6, pp. 345464.

B 143, vol. 6, pp. 105109.

B 143, vol. 6, pp. 319344.

The native population of (Steward)

tropical, The use of wild plants in (Lévi-Strauss) - -

See also Ecuador, Guiana Indians, 'Tierra del Fuego, B and other countries of South America.

South American cultures: An interpretative summary (Steward).

South and Central America, Cultivated plants of B (Sauer).

South Carolina:

Beaufort, Ceramic remains from two sites near $B$ (Griffin).

Beaufort County, Some notes on a few sites in (Flannery).

Southeastern United States, The Indians of the (Swan- B ton).

Southern Hunters, The: An introduction (Cooper) ....

Spanish Conquest, Inca culture at the time of the B (Rowe).

Spain site (39LM301), The, a winter village in Fort B Randall Reservoir, South Dakota (Smith).

\section{Speck, Frank G.:}

Art processes in birchbark of the River Desert B Algonquin, a circumboreal trait.

Native tribes and dialects of Connecticut. A A Mohegan-Pequot diary.

Wawenock myth texts from Maine

143, vol. 5, pp. 669772.

143, vol. 6, pp. 487543.

143, vol. 6, pp. 465486.

143.

133, Anthrop. Pap. No. 22.

133, Anthrop. Pap. No. 21.

137.

B

143, vol. 1, pp. 1315.

143, vol, 2 , pp. 183330.

169, Riv. Bas.

Surv. Pap. No.

11.

128, Anthrop. Pap. No. 17.

43, 199 .

43,165 .

Spencer, Robert F. The North Alaskan Eskimo: A B 171. study in ecology and society. 
Spruce-tree House, Mesa Verde National Park B 41.

(Fewkes).

Squier, Robert J.; Drucker, Philip; and Heizer, B 170.

Robert F. Excavations at La Venta, Tabasco, 1955.

With appendixes by Jonas E. Gullberg, Garniss H.

Curtis, and A. Starker Leopold.

Star Village: A fortified historic Arikara site in Mercer County, North Dakota (Metcalf). In press.

Steedman, Elsie Viault, editor. Ethnobotany of the Thompson Indians of British Columbia, based on field notes by James A. Teit.

Steggerda, Morris:

A description of thirty towns in Yucatan, Mexico.

Anthropometry of South American Indians

Mestizos of South America

B 185, Riv. Bas. Surv.

Pap. No. 27.

A 45,441 .

Some ethnological data concerning one hundred Yucatan plants.

The pigmentation and hair of South American $B$ Indians.

Stevenson, James:

Ceremonial of Hasjelti Dailjis and mythical sand painting of the Navajo Indians.

Illustrated catalogue of collections obtained from the Indians of New Mexico and Arizona in 1879.

Illustrated catalogue of collections obtained from the Indians of New Mexico in 1880.

Illustrated catalogue of collections obtained from pueblos of Zuñi, New Mexico, and Wolpi, Arizona, in 1881.

Stevenson, Matilda Coxe:

Ethnobotany of the Zurii Indians............. A 30,31.

The religious life of the Zuni child........... A $\mathbf{5}, 533$.

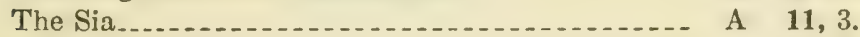

The Zuñi Indians, their mythology, esoteric fra- A 23, 3. ternities, and ceremonies.

Stevenson, Tilly E. See Stevenson, Matilda C.

Steward, Julian H.:

Ancient caves of the Great Salt Lake region _..... $\quad$ B 116.

Archeological reconnaissance of southern Utah.... B 128, Anthrop. Pap. No. 18.

Basin-plateau aboriginal sociopolitical groups_...- B 120.

Culture areas of the Tropical Forests............ B 143, vol. 3, pp. 883899.

Lemhi Shoshoni physical therapy _........... B 119, Anthrop. Pap.

No. 5 ,

Panatübiji', an Owens Valley Paiute........... B 119, Anthrop. Pap.

No. 6 .

Some western Shoshoni myths.............. B 136, Anthrop. Pap.

No. 31. 
Steward, Julian H.-Continued

South American cultures: An interpretative sum- B mary.

The Cirum-Caribbean tribes: An introduction....

The native population of South America B

143, vol. 5, pp. 669772 .

B 143, vol. 4, pp. 141.

B 143, vol. 5, pp. 655668.

The Witotoan tribes

B 143, vol. 3, pp. 749762.

Tribes of the Montaña: An introduction

Western Tuconoan tribes

B 143, vol. 3 , pp. 507533.

B 143, vol. 3, pp. 737748.

editor. Handbook of South American Indians. B 143.

Vol. 1. The Marginal tribes. Vol, 2. The Andean civilizations. Vol. 3. The Tropical Forest tribes. Vol. 4. The Circum-Caribbean tribes. Vol. 5. The Comparative ethnology of South American Indians. Vol. 6. Physical anthropology, linguistics, ana cultural geography of South American Indians.

and Métraux, Alfred:

The Peban tribes.........................

Tribes of the Peruvian and Ecuadorian Montaña.

B 143 , vol. 3, pp. 727736.

B 143, vol. 3, pp.535656.

Stewart, T. D.:

Deformity, trephining, and mutilation in South American Indian skeletal remains.

Description of the skeletal remains from Doniphan and Scott Counties, Kans. (appendix).

Pathological changes in South American Indian skeletal remains.

Skeletal remains from the Buena Vista sites, California (appendix).

Skeletal remains from the Peachtree Site, North B Carolina (appendix).

Skeletal remains from the Whitewater District, B eastern Arizona (appendix).

and Newman, Marshall T. Anthropometry of B South American Indian skeletal remains.

Stimulants and narcotics (Cooper).

Stirling, M. W.:

An archeological reconnaissance in Southeastern B Mexico.

Historical and ethnographical material on the $B$ Jivaro Indians.

Origin myth of Acoma and other records...... B

Stone monuments of southern Mexico _......... B

Stone monuments of the Río Chiquito, Veracruz, B Mexico.

The use of the atlatl on Lake Patzcuaro, Michoa- B can.

143, vol. 6, pp. 4348.

174.

143, vol. 6, pp. 4952 .

130.

131.

126.

143 , vol. 6, pp. 1942.

143 , vol. 5, pp. 525558.

164, Anthrop. Pap. 53.

117.

135.

138.

157, Anthrop. Pap. No. 43.

173, Anthrop. Pap. No. 59. 
Stone, Doris:

The basic cultures of Central America

B 143, vol. 4, pp. 169193

The Northern Highland tribes: The Lenca

143 , vol. 4 , pp. 205 217

Stone art (Fowke)

13,47 .

Stone implements of the Potomac-Chesapeake tide- A 15,3. water province (Holmes).

Stone monuments of southern Mexico (Stirling)......

Stone monuments of the Río Chiquito, Veracruz, B Mexico (Stirling).

Stones, Perforated, from California (Henshaw) _...... B

Stout, David B.:

The Choco

$$
138 .
$$

157, Anthrop. Pap. No. 43.

2.

143, vol. 4, pp. 269276.

The Cuna.............. B

Strachey vocabulary, The original, of the Virginia B Indian language (Harrington).

\section{Strong, Duncan :}

The archeology of Central America: An introduc- B tion.

The archeology of Costa Rica and Nicaragua....

'The archeology of Honduras.

and Johnson, Frederick. Anthropological needs and possibilities in Central America.

Structural investigations in 1943 (La Venta, Tabasco) B (Wedel).

Structures, Religious (Bennett)

143, vol. 4, pp. 257268.

157, Anthrop. Pap. No. 46.

143, vol. 4, pp. 6970.

143, vol. 4, pp. 121142.

B 143, vol. 4, pp. 71120.

143, vol. 4, pp. 293296.

153, 34-79.

143, vol. 5 , pp. 2951.

Studies in Central American picture writing (Holden)_

Study, An introductory, of the arts, crafts, and customs of the Guiana Indians (Roth).

Study of Pueblo architecture, A (V. Mindeleff) ........

Study of Siouan cults, A (Dorsey) . ..................

Study of the manuscript Troano, A (Thomas) .........

Sturtevant, William C. Comment on Gertrude P. Kurath's "Effects of Environment on CherokeeIroquois Ceremonialism, Music, and Dance."

Stutsman Focus, The: An aboriginal culture complex in the Jamestown Reservoir area (Wheeler). In press.

Sub-Andean tribes of the Cauca Valley (Hernández de Alba).

Suicide, Iroquois: A study in the stability of a culture pattern (Fenton).

Suicide, Mohave ethnopsychiatry and: The psychiatric knowledge and the psychic disturbances of an Indian tribe (Devereux).

Sumo, Paya, and Jicaque, The Mosquito. The Carib- B bean Lowland tribes: (Kirchhoff).

$1,205$.

$38,25$.

8,3 .

11,351 .

5.

180, pp. 197-203.

185, Riv. Bas. Surv. Pap. No. 30.

B 143, vol. 4, pp. 297327.

128, Anthrop. Pap. No. 14.

175.

143, vol. 4, pp. 219229 . 
Sumu Indians. See Miskito and Sumu Indians.

Sun Dance of the Northern Ute, The (Jones)

\section{Swanton, John R.:}

Aboriginal culture of the Southeast

Early history of the Creek Indians and their neighbors.

Haida texts and myths.

Indian tribes of North America, The

Indian tribes of the lower Mississippi Valley and adjacent coast of the Gulf of Mexico.

Linguistic material from the tribes of southern Texas and northeastern Mexico.

Myths and tales of the Southeastern Indians.....

Religious beliefs and medical practices of the Creek Indians.

Social and religious beliefs and usages of the Chickasaw Indians.

Social organization and social usages of the Indians of the Creek Confederacy.

Source material for the social and ceremonial life of the Choctaw Indians.

Source material on the history and ethnology of the Caddo Indians.

Structural and lexical comparison of the Tunica, Chitimacha, and Atakapa languages, A.

The Indians of the Southeastern United States...

The quipu and Peruvian civilization...........

Tlingit Indians, The ............................

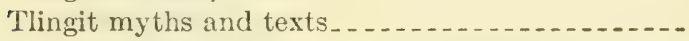

and Dorsey, James Owen. Biloxi-Ofo dictionary. and Gatschet, Albert S. A dictionary of the Atakapa language.

and Thomas, Cyrus. Indian languages of Mexico B and Central America.

edilor. Choctaw dictionary (Byington)

editor. Notes on the Creek Indians (Hewitt) ....

See also Bulletin 40 (pt. 1).

Swimmer manuscript, The: Cherokee sacred formulas and medicinal prescriptions (Mooney and Olbrechts). Symbols, Day, of the Maya year (Thomas) ..........

Symposium on Cherokee and Iroquois culture (Fenton and Gulick, editors).

Symposium on local diversity in Iroquois culture B (edited by William N. Fenton).

Synonymy, Skittagetan (Henshaw)

Taino. The ethnography of Hispaniola

Tajin Totonac, The: Part 1. History, subsistence, P shelter, and technology (Kelly and Palerm).
B

157, Anthrop. Pap.

No. 47.

A $42,673$.

73.

29.

145.

43.

127.

88.

A 42,473 .

A $\quad 44,169$.

$42,23$.

103.

132.

68.

137.

133, Anthrop. Pap.

No. 26.

26, 391 .

39.

47.

108.

44.

46.

123, Anthrop. Pap. No. 10.

99.

A $\quad 16,199$.

B 180 .

B 149.

M 5 .

B 143, vol. 4, pp. 522539.

13. 
Talamanca Division, The. The Caribbean Lowland B tribes: (Jolinson).

Tales of Cochiti Indians (Benedict)

Taos Pueblo, New Mexico, Factionalism at (Fenton). B

Tapanyuna, and Apiacá, The Cayabí, (Nimuendajú)._ B

Tapirape, The (Wagley and Galvão)

"Tapuya," The (Lowie)

Tarairiu, The (Lowie)

Tattooing and face and body painting of the Thompson Indians, British Columbia (Teit).

Tax, Sol. Penny capitalism, a Guatemalan Indian P economy.

Taylor, Douglas. The Caribs of Dominica

Technical notes on concave mirrors (Gullberg) (appen$\operatorname{dix} 3)$.

Technique in the music of the American Indian (Densmore).

Technological analyses (La Venta, Tabasco) (Shepard) _

Technology, or the science of industries (Powell) .......

Teit, James A.:

Tattooing and face and body painting of the Thompson Indians, British Columbia (edited by Franz Boas).

The Salishan tribes of the western plateaus (edited by Franz Boas).

With Haeberlin, H. K., and Roberts, Helen H. Coiled basketry in British Columbia and surrounding region.

See also Steedman, Elsie Viault.

Tenetehara, The (Wagley and Galvão)

Tennessee:

Archeological survey of Pickwick Basin in (Webb and DeJarnette).

eastern, An archeological survey of the Norris Basin in (Webb)

Middle, Two prehistoric villages in (Myer)........

Pickwick Basin, Geology of the (Jones) ...........

River in northern Alabama, An archeological survey of Wheeler Basin on the (Webb).

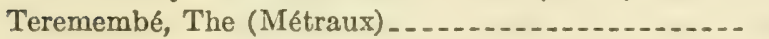

Terena and Caduveo of southern Mato Grosso, Brazil P (Oberg).

Teton Sioux music (Densmore)
143, vol. 4, pp. 231251.

98.

164, Anthrop. Pap.

No. 56.

143 , vol. 3 , pp. $307-$ 320 .

143, vol. 3, pp. 167178.

143 , vol. 1 , pp. 553556.

143, vol. 1, pp. 553556.

A 45,397 .

16.

119, Anthrop. Pap. No. 3.

170.

151, Anthrop. Pap. No. 36.

153, 234-240.

$20, \operatorname{xxrx}$.

A $\quad 45,397$.

A 45,23 .

$41,119$.

B 143, vol. 3, pp. 137148.

B 129 .

118.

A 41,485 .

$129,327$.

122.

143, vol. 1, pp. 573574.

9.

B 61. 
Tewa Indians:

Ethnobotany of the (Robbins, Harrington, and B 55. Freire-Marreco).

Ethnogeography of the (Harrington)

Ethnozoology of the (Henderson and Harrington)

Texas, southern, Linguistic material from the tribes of (Swanton).

Textile art:

Form and ornament in (Holmes)

Prehistoric, of eastern United States (Holmes) ..... Textile fabrics:

of ancient Peru (Holmes) Texts:

29,29 .

56.

127.

Prehistoric, of the United States (Holmes) _...... $\Lambda \quad \mathbf{3}, 393$.

Alsea (Frachtenberg)

Biloxi (Dorsey and Swanton)

Chinook (Boas) _............................... B

Dakota (Riggs)

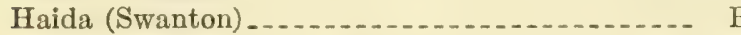

Kathlamet (Boas) _..........................

Kutenai (Boas and Chamberlain) _............. B

Picuris (Harrington and Roberts) _............ A

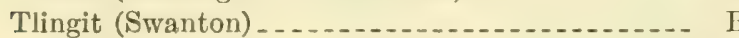

Tsimshian (Boas) _........................... B

Wawenock (Speck) .......................... A

Thalbitzer, William. See Bulletin 40 (pt. 1).

Therapy, physical, Lemhi Shoshoni (Steward)

Thomas, Cyrus:

A study of the manuscript Troano.............

Aids to the study of the Maya codices.

Burial mounds of northern sections of the United States.

Catalogue of prehistoric works east of the Rocky Mountains.

Day symbols of the Maya year.

Introduction to "Indian land cessions" (Royce) - -

Mayan calendar systems

Notes on certain Maya and Mexican manuscripts_

Numeral systems of Mexico and Central America

Report on the mound explorations of the Bureau of Ethnology.

The circular, square, and octagonal earthworks of Ohio.

The Maya year................................

The problem of the Ohio mounds.........

Work in mound exploration of the Bureau of Ethnology.

and Swanton, John R. Indian languages of Mexico and Central America and their geographical distribution.

Thomas, Robert K. The Redbird Smith movement_--

B 67.

C 5.

A 6, 189 .

A 13,3 .

7.

47.

20.

9.

29.

26.

59.

43, 289 .

39.

27.

43,165 .

119.

A 6, 253.

A 5,3 .

B 12 .

A $\mathbf{1 6 , 1 9 9 .}$

A 18,521 .

A 19,693, and 22 (pt.

1), 197.

A 3,3 .

A $\mathbf{1 9 , 8 5 3 .}$

A 12,3 .

10.

B 18.

B 8 .

B 4 .

B 44.

B $180, p p .159-166$. 
Thompson Indians:

British Columbia, Tattooing and face and body A 45, 397 . painting of the (Teit).

of British Columbia, Ethnobotany of the (Steed- A 45, 441. man).

Tierra del Fuego, Bibliography of tribes of (Cooper) ...

Tierradentro, Colombia, The archeology of San Agustín and (Hernández de Alba).

Tipi rings, Stone, in north-central Montana and the adjacent portion of Alberta, Canada: Their historical, ethnological, and archeological aspects (Kehoe).

Tlingit community, The story of a: A problem in the relationship between archeological, ethnological, and historical methods (de Laguna).

Tlingit Indians, The (Swanton)

Tlingit language. See Bulletin 40 (pt. 1).

Tlingit myths and texts (Swanton)

B 63 .

B 143, vol. 2, pp. 851859 .

B 173, Anthrop. Pap. No. 62.

Tobacco among the Karuk Indians of California (Harrington).

Tocantins River region, Little-known tribes of the (Nimuendajú).

Tonawanda longhouse ceremonies: Ninety years after Lewis Henry Morgan (Fenton).

Towers of southwestern Colorado, Prehistoric villages, B castles, and (Fewkes).

Tozzer, Alfred M. Excavation of a site at Santiago B Ahuitzotla, D. F. Mexico.

Tracy, Edwin S. See Annual Report 22, pt. 2, p. 5.

Traditional origin of the Fox society known as "The A 40,541. Singing Around Rite" (Michelson).

Traditions:

Osage (Dorsey)

Tusayan migration (Fewkes)

Trails, Indian, of the Southeast (Myer)
Traps (Cooper)

Trephining, and mutilation in South American Indian B skeletal remains, Deformity (Stewart).

Trephining, Prehistoric, and cranial amulets (R. C 5 . Fletcher).

Trephining, Primitive, in Peru (Muñiz and McGee) .. Tres Zapotes, Mexico, Ceramic sequences at (Drucker). Tres Zapotes, Mexico, Ceramics of (Weiant) Tribal society, Wyandot government: A short study of (Powell).

Tribes, certain Indian, of the United States, Tubercu- B losis among (Hrdlička).

Tribes, Indian, of the Upper Missouri (Denig) ........-

Tribes and languages of southwestern Colombia, The native (Ortíz).

Tribes north of the Orinoco River, The (Kirchhoff)...-

A 16,3 .

B 140 .

B 139 .

A 1,57 .

42.

A 46, 375 .

B 143, vol. 2, pp. 911914.

B 143, vol.4, pp. 481493. 
Tribes of California (Powers)

Tribes of eastern Bolivia and the Madeira Headwaters (Métraux).

Tribes of eastern Bolivia and western Matto Grosso, The native (Métraux).

Tribes of Ecuador, The historic (Murra)

Tribes of North America, with synonymy. Skittagetan family (Henshaw).

Tribes of northwestern Venezuela, The (Hernández de Alba).

Tribes of southern Colombia, The Highland (Hernández de Alba).

Tribes of the eastern slopes of the Bolivian Andes (Métraux).

Tribes of the extreme northwest (Dall)

Tribes of the Guianas (Gillin)

Tribes of the Juruá-Purús Basins (Métraux)

Tribes of the lower Amazon, Little-known (Nimuendajú).

Tribes of the lower and middle Xingú River (Nimuendajú).

Tribes of the lower Mississippi Valley and adjacent coast of the Gulf of Mexico (Swanton).

Tribes of the lower Tocantins River region, Little- B known (Nimuendajú).

Tribes of the middle and upper Amazon River (Métraux).

Tribes of the Montaña: An introduction (Steward) ...

Tribes of the North Colombia Lowlands (Hernaindez de Alba).

Tribes of the Peruvian and Ecuadorian Montaña (Stew- B ard).

Tribes of the right bank of the Guaporé River (Lévi- B Strauss).

Tribes of the Rio Negro Basin, The hunting and gather- B ing (Métraux).

Tribes of the Sierra Nevada de Santa Marta, Colombia B (Park).

Tribes of the Uaupes-Caqueta region (Goldman) _..... B

Tribes of the upper Xingú River (Lévi-Strauss) _.... B

Tribes of western Washington and northwestern Oregon C (Gibbs).

Tribes west and south of the Panama Canal, The B (Lothrop).

Troano manuscript, A study of the (Thomas)

Tropical Forest and Marginal tribes, Property among the (Lowie).
3.

143, vol. 3, pp. 381454.

B 134.

B 143, vol. 2, pp. 785821.

M 5.

143, vol. 4, pp. 469 474.

143, vol. 2, pp. 915961.

143, vol. 3 , pp. 465406.

1,1 .

143, vol. 3, pp. 799860.

143, vol. 3, pp. 657686.

143, vol. 3, pp. 209211.

143, vol. 3, pp. 213243.

43.

143, vol. 3, pp. 203208.

143, vol. 3 , pp. $687-$ 712.

143 , vol. 3 , pp. $507-$ 533.

143, vol. 4, pp. 329 338.

143, vol. 3, pp. 535656.

143, vol. 3 , pp. 371379 .

143, vol. 3, pp. 861867.

143, vol. 2, pp. 865886.

143, vol. 3, pp. 763798.

143, vol. 3, pp. 321348.

$1,157$.

143, vol. 4, pp. 253256.

5.

143, vol. 5, pp. 351367. 
Tropical Forest and Marginal tribes, Social and political B organization of the (Lowie).

Tropical Forests, Culture areas of the (Steward)

Tropical Forests, The: An introduction (Lowie) ....... Troyville mounds, The, Catahoula Parish, La. (Walker)

Trumbull, James Hammond. Natick dictionary . . . . Tschopik, Harry, Jr.:

Aymara, The

Highland communities of central Peru

Tsimshian language. See Bulletin 40 (pt. 1).

Tsimshian mythology (Boas)

Tsimshian texts (Boas)

T'sim si-an', Note on the use of numerals among the (Gibbs).

Tuberculosis among certain Indian tribes of the United States (Hrdlička).

Tucanoan tribes, Western (Steward)

Tucuna, The (Nimuendajú)

Tunica language. See Bulletin 68 .

Tupi-Cawahíb, The (Lévi-Strauss)

Tupinamba, The (Métraux)

Turiwara and Aruã, The (Nimuendajú)

Turner, Lucien M. Ethnology of the Ungava district, Hudson Bay Territory.

Tusayan and Cibola architecture (V. Mindeleff)

Tusayano clans, Localization of (C. Mindeleff)

Tusayan Flute and Snake ceremonies (Fewkes)

Tusayan katcinas (Fewkes)

Tusayan migration tradition (Fewkes)

Tusayan Snake ceremonies (Fewkes)

Two prehistoric villages in Middle Tennessee (Myer)..

Two rock shelters near Tucumcari, New Mexico (Dick)

Two summers' work in pueblo ruins (Fewkes)

Uapés-Caquetá region, Tribes of the (Goldman)

Ungava district, Ethnology of the (Turner)

Upper lakes, Wild-rice gatherers of the (Jenks)

Uru-Chipaya, The (La Barre)

Use of wild plants in tropical South America (Lévi- B Strauss).

Uses of plants by the Chippewa Indians (Densmore) --
143 , vol. 5, pp. 313350.

B 143 , vol. 3 , pp. $883-$ 899.

143, vol. 3 , pp. 1-56. 113.

25.

B 143, vol. 2, pp. 501573.

P 5.

A $31,29$.

B 27.

C 1,155 .

B 42.

B 143, vol. 3, pp. 737748 .

B 143, vol. 3, pp. 713725 .

B 143 , vol. 3, pp. 299305.

B 143, vol. 3, pp. 95133.

B 143, vol. 3, pp. 193198.

A 11,159 .

A 8,3 .

A 19,635 .

A 19,957 .

A $15,245$.

A 19,573 .

A $16,267$.

A 41,485 .

B 154, Riv. Bas.

Surv. Pap. No.

5 , pt. 1 .

A 22 (pt. 1), 3.

B 133, vol. 3, pp. 763798.

A $11,159$.

A $19,1013$.

B 143 , vol. 2 , pp. 575-

585.

143, vol. 6, pp. 465486.

A $44,275$. 
Uses of plants by the Indians of the Missouri River A 33, 43 . region (Gilmore).

Utah, southern, Archeological reconnaissance of B 128, Anthrop. Pap. (Steward).

Ute music, Northern (Densmore)

B

$$
\text { No. } 18 .
$$

75.

Valcárcel, Luis E. :

Cuzco archeology -

Indian markets and fairs in Perú

The Andean calendar

Valladolid Maya enumeration (Harrington)

Venezuela:

The archeology of (Kidder)

The tribes of northwestern (Hernández de Alba)..

The Yaruros of the Capanaparo River (Petrullo) -

Venezuelan Llanos, Food-gathering tribes of the (Kirchhoff).

Verde River and Walnut Creek valleys, Arizona, A Antiquities of upper (Fewkes).

Verde Valley, Aboriginal remains in (C. Mindeleff) ......

Village of the Great Kivas on the Zuñi Reservation, B New Mexico, The (Roberts).

Villages and village sites east of the Mississippi, Native (Bushnell).

Villages, castles, and towers of southwestern Colorado, B Prehistoric (Fewkes).

Villages in Middle Tennessee, Two prehistoric (Myer) -

Villages of the Algonquian, Siouan, and Caddoan tribes west of the Mississippi (Bushnell).

Virginia, The Pamunkey Indians of (Pollard) .........

Vocabularies [of tribes of the extreme northwest] (Gibbs and Dall).

Vocabulary of the Kiowa language (Harrington) -...---

Voget, Fred W.:

Comment on Robert K. Thomas's "The Redbird B Smith Movement."

Current trends in the Wind River Shoshone Sun B Dance.

Wagley, Charles, and Galyão, Eduardo:

The Tapirapé.

B

143, vol. 3, pp. 167-

178.

The Tenetehara

B 143 , vol. 3, pp. $137-$ 148.

Wakashan languages, Bibliography of the (Pilling)__._ $\quad$ B 19. 
Walker, Winslow M. The Troyville mounds, Cata- B 113.

houla Parish, La.

Wallace, Anthony F. C.:

Cultural composition of the Handsome Lake B 180, pp. 139-151. religion.

The modal personality of the Tuscarora Indians as $\mathrm{B} \quad \mathbf{1 5 0 .}$ revealed by the Rorschach test.

See also Fenton, William N., editor.

Walnut Creek and upper Verde River valleys, Arizona, A 28, 181.

Antiquities of (Fewkes).

Warfare, cannibalism, and human trophies (Métraux)_ B 143, vol.5, pp. 383409.

Warrau, The (Kirchhoff) _... . . . 881.

Washington, western, Tribes of (Gibbs) _........ C 1, 157.

Water lily in Maya art, The: A complex of alleged B 151, Anthrop. Pap.

Asiatic origin (Rands).

Wawenock myth texts from Maine (Speck) .........

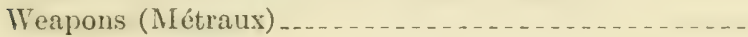

Weavers, Navajo (Matthews) No. 34.

A 43,165 .

B 143, vol. 5, pp. 229263.

Weaving (O'Neale)

A 3,371 .

B 143, vol. 5, pp. 97138.

\section{Webb, William S.:}

An archeological survey of the Norris Basin in eastern Tennessee.

An archeological survey of Wheeler Basin on the Tennessee River in northern Alabama.

and DeJarnette, David L. Archeological survey of Pickwick Basin in the adjacent portions of the States of Alabama, Mississippi, and Tennessee (with four additional papers).

Wedel, Waldo R.:

An introduction to Kansas archeology. With a description of the skeletal remains from Doniphan and Scott Counties, Kans., by T. D. Stewart.

An introduction to Pawnee archeology ...........

Archeological investigations at Buena Vista Lake, Kern County, California.

Archeological materials from the vicinity of Mobridge, South Dakota.

Observations on some nineteenth-century pottery vessels from the Upper Missouri.

Prehistory and the Missouri Valley development program: summary report on the Missouri River Basin archeological survey in 1948.

Prehistory and the Missouri Valley development program: summary report on the Missouri River Basin archeological survey in 1949.

See also Drucker, Philip.

Weiant, C. W. An introduction to the ceramics of Tres Zapotes, Veracruz, Mexico.

B 157, Anthrop. Pap. No. 45.

B 164, Anthrop. Pap. No. 51.

B 154, Riv. Bas. Surv. Pap. No. 1.

B 154, Riv. Bas. Surv. Pap. No. 2. 
Weights, and calendars, Numbers, measures (Ben- B nett).

West, Robert C. Cultural geography of modern Taras- P can area.

West Indies. See Aborigines of Porto Rico; Prehistoric island culture area.

West Indies, The: An Introduction (Rouse)

Whaling in Asia and America, Aconite poison (Heizer) ..

Wheat, Joe Ben. An archeological survey of the Addicks Dam Basin, southeast Texas.

Wheeler, R. P. The Stutsman Focus: An aboriginal culture complex in the Jamestown Reservoir area. In press.

Wheeler Basin, northern Alabama, Archeological survey of (Webb).

White, Leslie A.:

New material from Acoma.

The Acoma Indians

The Pueblo of Sia, New Mexico. In press......

White, Theodore E. Butchering techniques at the Dodd and Phillips Ranch sites (appendix).

Whitewater District, eastern Arizona, Archeological remains in the. Part I: House types (Roberts).

Whitewater District, eastern Arizona, Archeological remains in. Part II: Artifacts and burials (Roberts).

Whitewater District, eastern Arizona, Skeletal remains from (Stewart).

Wilbanks site (9CK-5), The, Georgia (Sears) ..........

Wild-rice gatherers of the upper lakes (Jenks) ........

Willey, Gordon R.:

Ceramics

Prehistoric settlement patterns in the Virú Valley, B Peru.

The archeology of the Greater Pampa..........

The culture of La Candelaria

and Jennings, Jesse D., and Newman, Marshall T. B

The Ormond Beach Mound, East Central Florida.

Willis, Bailey (collaborator). Early man in South America.

Wilson, Elsie A. The basal metabolic rates of South American Indians.

Wind River Shoshone Sun Dance, The (Shimkin) _...--

Winnebago tribe, The (Radin)

143, vol. 4, pp. 495496.

B 133, Anthrop. Pap. No. 24.

154, Riv. Bas. Surv. Pap. No. 4, Pt. 1. 185, Riv. Bas. Surv. Pap. No. 30.

122.

B 136, Anthrop. Pap. No. 32.

A 47,17 .

B 184 .

B 158,165 .

B 121 .

B 126.

B 126,153 .

B 169.

A $19,1013$.

B 143 , vol. 5, pp. 139204.

155.

B 143, vol. 1, pp. 2546.

B 143, vol. 2, pp. 661672 .

164, Anthrop. Pap. No. 49.

B 52.

B 143, vol. 6, pp. 97104.

B 151, Anthrop. Pap. No. 41.

A 37,35 . 
Winship, C. P. The Coronado expedition, 1540-1542

Witotoan tribes, The (Steward)

Witthoft, John. Eastern Woodlands community typology and acculturation.

Wolpi, Arizona, Illustrated catalogue of collections from, in 1881 ( $\mathrm{J}$. Stevenson).

Wood, W. Raymond, and Woolworth, Alan R. The archeology of a small trading post (Kipp's Post, $32 \mathrm{MN1}$ ) in the Garrison Reservoir, North Dakota.

Woodruff ossuary, a prehistory burial site in Phillips County, Kansas (Kivett).

Woodward, Arthur. Trade goods, report on (appendix 2).

Woolworth, Alan R., and Wood, W. Raymond. The archeology of a small trading post (Kipp's Post, $32 \mathrm{MN} 1$ ) in the Garrison Reservoir, North Dakota.

Wright, Fred. Eugene (collaborator). Early man in South America.

Wyandot government: A short study of tribal society (Powell).

Xingú River, Tribes of the lower and middle (Nimuendajú).

Xingú River, Tribes of the upper (Lévi-Strauss) .......

Yahgan, The (Cooper)

Yaqui music, Yuman and (Densmore)

Yarrow, H. C.:

A further contribution to the study of the mortuary customs of the North American Indians.

Introduction to the study of mortuary customs among the North American Indians.

Yaruros of the Capanaparo River, Venezuela, The B (Petrullo).

Yucatan, southern, Maya Indians of (Gann)

Iucatan plants (Steggerda)

Yucatan towns (Steggerda)

Yuman and Serian languages. See Comparative lexicology of (Hewitt).

Yuman and Yaqui music (Densmore)

Zuñi, New Mexico, Illustrated catalogue of collections from, in 1881 (J. Stevenson).

Zuñi ceremonialism, Introduction to (Bunzel) Zuñi child, The religious life of the (T. E. Stevenson) Zuñi creation myths, Outlines of (Cushing)
A 14,329 .

B 143 , vol. 3 , pp. 749762.

180, pp. 67-76.

3,511 .

B 176, Riv. Bas. Surv.

Pap. No. 20.

B 154, Riv. Bas. Surv. Pap. No. 3.

166.

176, Riv. Bas. Surv. Pap. No. 20.

B 52.

A $\quad 1,57$.

B 143, vol. 3, pp. 213243.

B 143, vol. 3, pp. 321348.

B 143 , vol. 1, pp. 81106.

B 110 .

A $\quad 1,87$.

4.

123, Anthrop. Pap. No. 11.

64.

B 136, Anthrop. Pap.

No. 29.

B 136, Anthrop. Pap.

No. 30 .

17, 299*.

B 110.

A 3,511 .

A $\quad \mathbf{4 7 ,} 467$.

A 5,553 .

A 13,321 . 
Zuñi culture-growth, Pueblo pottery as illustrative of A 4, 467.

(Cushing).

Zuñi fetiches (Cushing)

A 2,3 .

Zuñi Indians (M. C. Stevenson)

A 23,3 .

Zuñi Indians, Ethnobotany of the (M. C. Stevenson)-.

Zuñi katcinas (Bunzel).

A 30,31 .

Zuñi Reservation, New Mexico, The Village of the B

A 47,837 .

Great Kivas on the (Roberts).

Zuñi ritual poetry (Bunzel)

A $47,611$. 





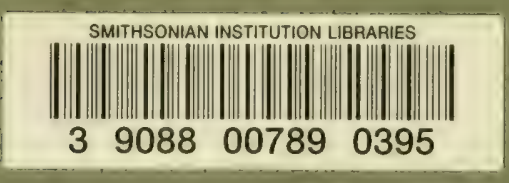






\section{HECKMAN \\ BINDERY INC.}

\section{MAR 98}

Bound -To-Please N. MANCHESTER 
- 